\title{
EFEITO DA MORTE SÚBITA DO CITROS SOBRE ESTADO NUTRICIONAL DAS VAR. PERA RIO E NATAL NO LIMOEIRO CRAVO
}

LUCIANA BERTOLOTTI

Engenheiro Agrônomo

Orientador: Prof. Dr. QUIRINo Augusto de CAMARgo CARMELlo

Dissertação apresentada à Escola Superior de Agricultura "Luiz de Queiroz", Universidade de São Paulo, para obtenção do título de Mestre em Agronomia, Área de Concentração: Solos e Nutrição de Plantas.

PIRACICABA

Estado de São Paulo - Brasil

Dezembro - 2004 


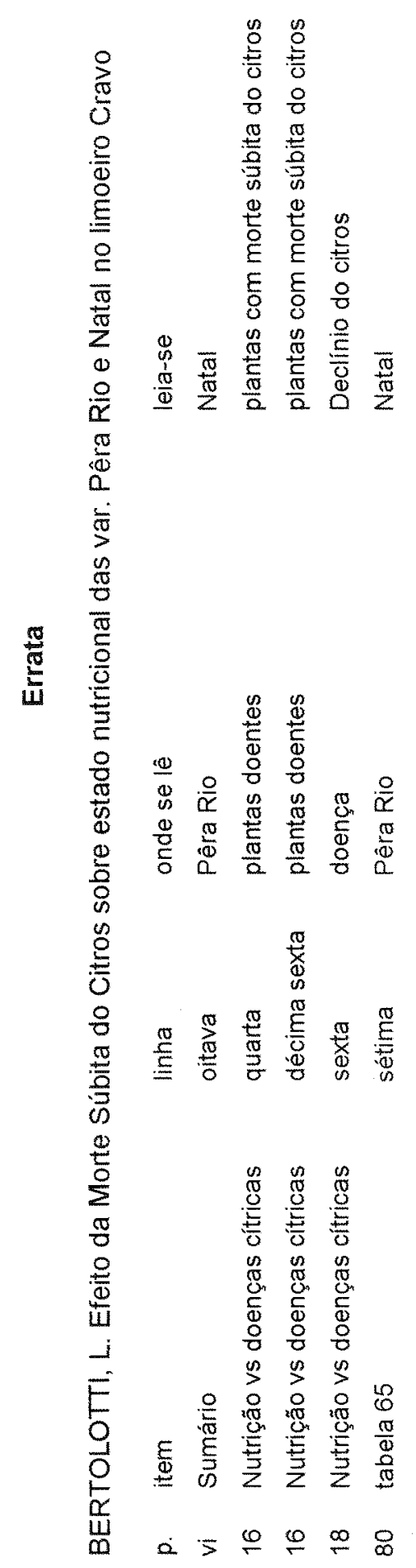


Dados Internacionais de Catalogação na Publicação (CIP) DIVISÃO DE BIBLIOTECA E DOCUMENTAÇĀO - ESALQ/USP

\section{Bertolotti, Luciana}

Efeito da morte súbita do citros sobre estado nutricional das var. Pêra Rio e Natal no limoeiro Cravo / Luciana Bertolotti. - - Piracicaba, 2004.

$89 \mathrm{p}$.

Dissertação (Mestrado) - - Escola Superior de Agricultura Luiz de Queiroz, 2004.

Bibliografia.

1. Fungo fitopatogênico 2. Limão 3. Morte súbita (doença de plantas) 4. Nutrição mineral I. Título

CDD 634.334

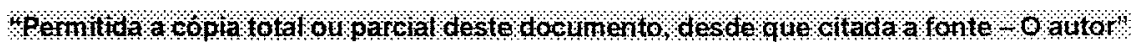


A Deus

Minha Gratidão.

A meus pais, José Augusto e Leonor.

Por tudo que significam em minha vida,

Por toda a estima compreensão, amor; por

$\mathcal{N a ̃ o ~ m e d i r e m ~ e s f o r c ̧ o s ~ p a r a ~ a ~ m i n h a ~ f o r m a c ̧ a ̃ o ~}$

Pessoal além da grande amizade

Dedico.

A minha irmã Ana Paula, e aos meus avós Letícia, Aristides, Josefa (in memorian) e Laurindo (in memorian)

Pelo carinho e confiança

Ofereço 


\section{AGRADECIMENTOS}

A Deus por me conceder infinitas bênçãos em minha vida.

À Escola Superior de Agricultura "Luiz de Queiroz" pela minha formação e da qual tenho orgulho de ser filha.

Ao Prof. Dr. Quirino Augusto de Camargo Carmello, não apenas pela sua inestimável orientação, mas pela sua amizade e compreensão durante esses anos.

Aos professores Francisco Antonio Monteiro, Antônio Roque Dechen, Godofredo César Vitti, Décio Barbin e Sônia Maria de Stefano Piedade pelos ensinamentos e sugestões.

Ao Conselho Nacional de Desenvolvimento Científico e Tecnológico (CNPq) pela concessão da bolsa.

À Coordenação do Programa em Solos e Nutrição de Plantas pela oportunidade.

Ả Cargill pela cessão da área e colaboração dos funcionários.

Aos funcionários Ednéia C. S. Mondoni, Lúcia H. S. P. Forti, Lurdes A. D. de González, Nivanda M. de M. Ruiz, Sueli M. A. Bovi e Luiz Silva pelo apoio técnico e principalmente pela amizade construída.

As minhas queridas "irmãs" Gláucia Regina Anti, Márcia Moreira Ayres de Souza, Raquel Capristano Moreira e Maria Cândida de Godoy Gasparoto, pela fidelidade em todos os momentos.

Aos amigos da "salinha" Edna, Karina, Cristiane, Dylnei, Suzana, Simeire, Olimpio, Haroldo e Gilberto pela amizade e colaboração.

Às pessoas pela ajuda na realização do trabalho e pela amizade, principalmente à Camila, Antônio Carlos, Daniela e João Paulo. 


\section{SUMÁRIO}

Página

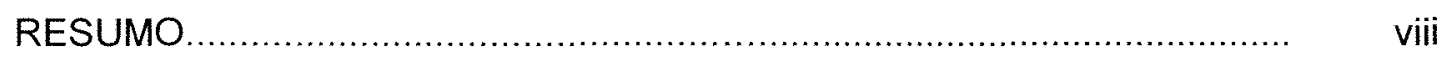

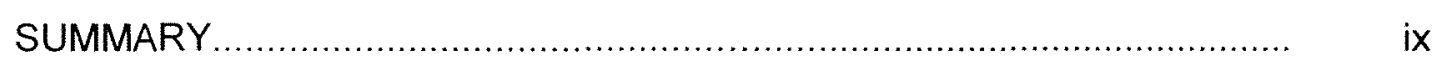

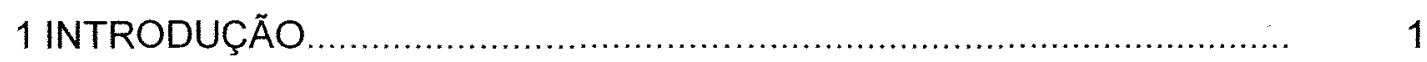

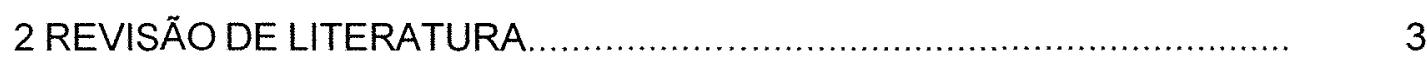

2.1 Histórico da Morte Súbita do citros....................................................

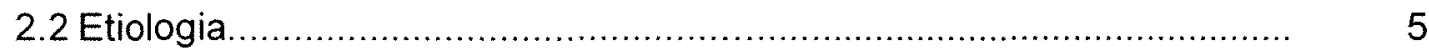

2.3 Sintomas da Morte Súbita do Citros..................................................

2.4 Nutrição mineral do citros...................................................................

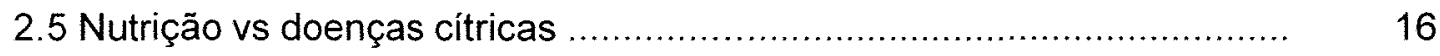

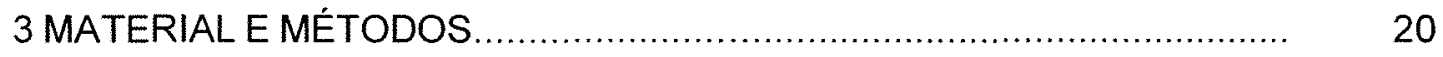

3.1 Localização da área experimental, variedade, tipo de solo.................... 20

3.2 Adubação realizada no período do experimento..................................... 22

3.3 Delineamento experimental............................................................... 22

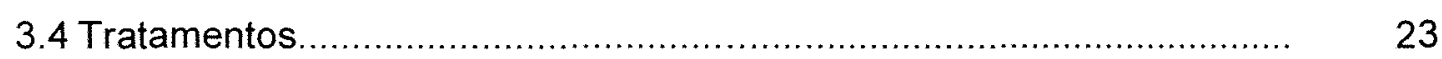

3.5 Amostragem das diversas partes da planta....................................... 23

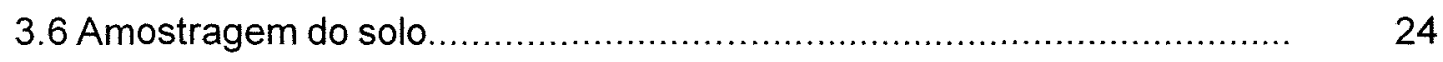

3.7 Determinações químicas nas amostras de planta e solo........................ 24

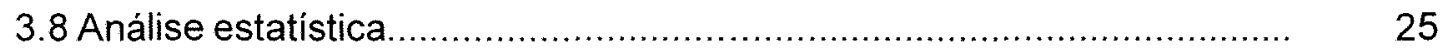

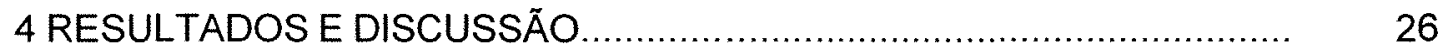

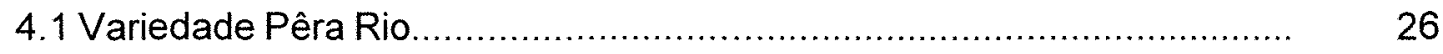

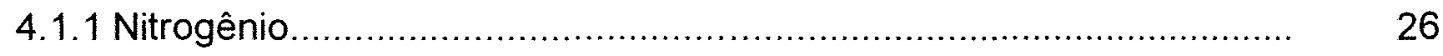

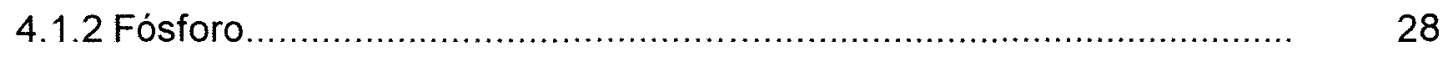

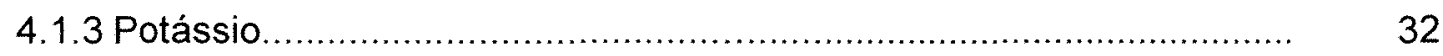

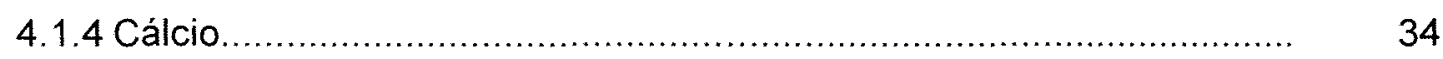




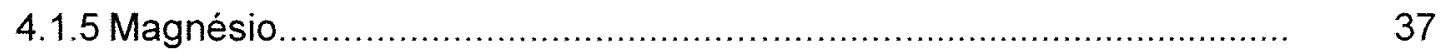

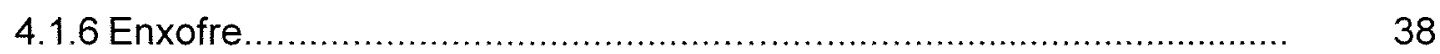

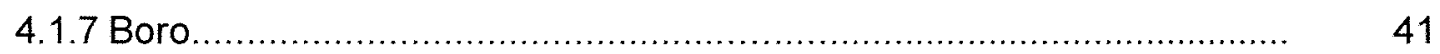

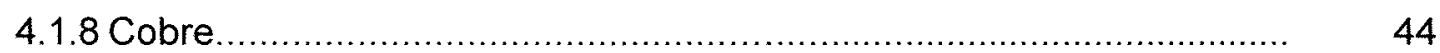

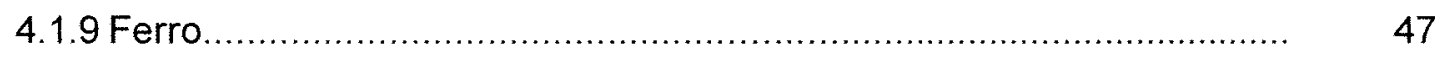

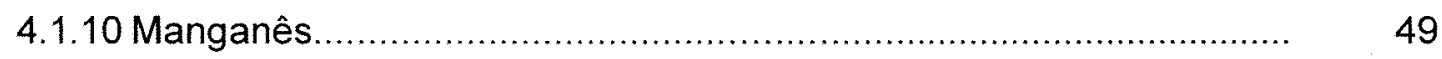

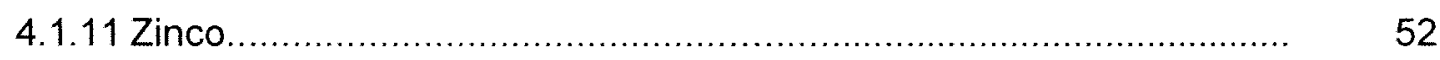

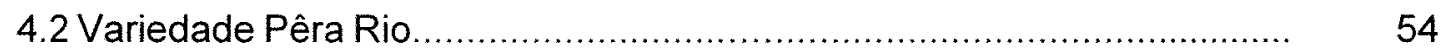

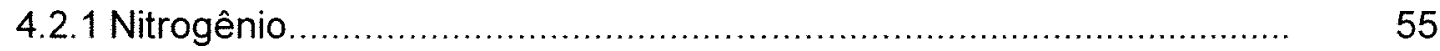

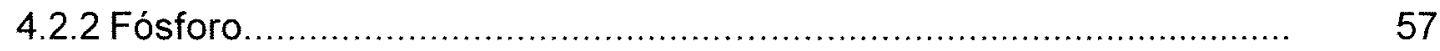

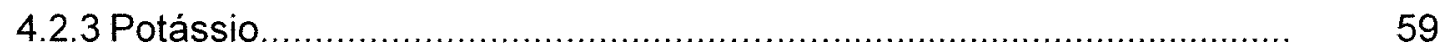

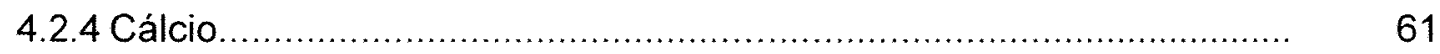

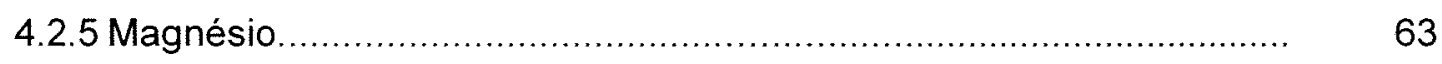

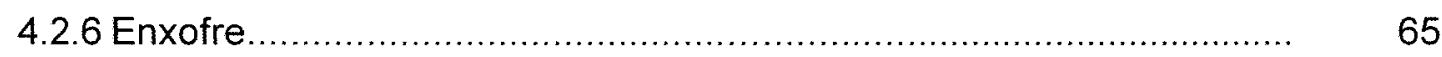

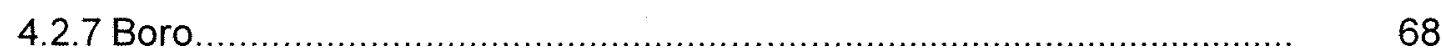

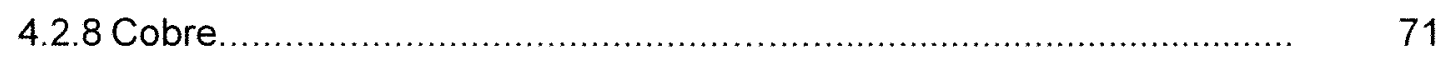

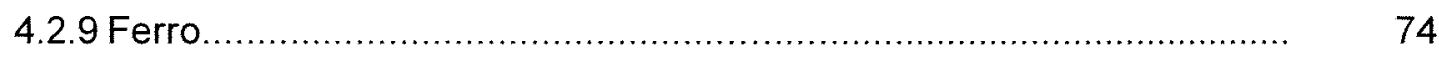

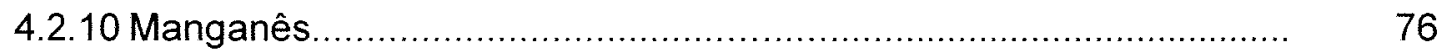

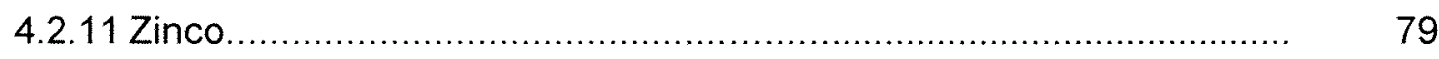

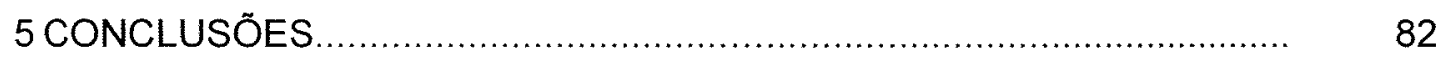

REFERÊNCIAS BIBLIOGRÁFICAS....................................................... 83 


\title{
EFEITO DA MORTE SÚBITA DO CITROS SOBRE ESTADO NUTRICIONAL DAS VAR. PERA RIO E NATAL NO LIMOEIRO CRAVO
}

\author{
Autora: LUCIANA BERTOLOTTI \\ Orientador: Prof. Dr. QUIRINO AUGUSTO DE CAMARGO CARMELLO
}

\section{RESUMO}

A citricultura brasileira é a maior do mundo, sendo o citros uma das principais culturas produzidas no Brasil, no entanto há 5 anos ela vem sofrendo com a chegada da morte súbita do citros, principalmente no sul do Triângulo Mineiro e norte de São Paulo. Com o objetivo de avaliar o estado nutricional de plantas em estágios de sintomatologia da morte súbita do citros e fazer o acompanhamento da fertilidade do solo nessas áreas, para fim de comparação da eficiência de absorção dos nutrientes, foram conduzidos dois experimentos em um pomar comercial situado no município de Frutal -MG. Utilizaram-se duas variedades de citros, 'Pêra Rio' e 'Natal', sobre o limoeiro 'Cravo' ambas com 14 anos. $O$ delineamento experimental foi o inteiramente casualizado com quatro tratamentos (plantas sadias e em três estágios da morte súbita) e quatro repetições, sendo dispostos em parcelas subdivididas no tempo. As plantas com morte súbita foram diagnosticadas através dos sintomas visuais. As coletas tiveram inicio em 24 de junho de 2003 e terminaram em 13 de dezembro do mesmo ano, e foram realizadas em intervalos regulares de 35 dias. Em cada coleta foram separadas as folhas, galhos, casca do tronco e raizes de cada planta para se determinar a concentração dos nutrientes, bem como o solo, onde foi feita a análise de 
fertilidade. Na variedade 'Pêra Rio', o comportamento dos nutrientes foram os seguintes: nas folhas, as concentrações de fósforo, potássio, enxofre e boro diminuíram com 0 avanço da doença e a de zinco aumentou; nos galhos, as concentrações de nitrogênio, fósforo, potássio diminuíram e as de cobre, ferro, manganês e zinco aumentaram; na casca do tronco, o ferro e o manganês diminuíram e finalmente nas raízes, as concentrações de nitrogênio, cálcio, enxofre, boro, ferro e zinco diminuíram. Na variedade 'Natal', o comportamento dos nutrientes foi um pouco diferente: nas folhas, a concentração de potássio diminuiu com o avanço da doença; nos galhos, as concentrações de nitrogênio, fósforo, potássio diminuíram e a de manganês aumentou; na casca do tronco, o potássio e o boro diminuiram e o magnésio e manganês aumentaram e finalmente nas raízes as concentrações enxofre, boro e zinco diminuiram. Quanto ao solo, o mesmo não se observou influência nas alterações nutricionais que ocorreram com as plantas, pois com a evolução da doença, os teores permaneceram inalterados. O comportamento nutricional mostrou-se variado quanto às épocas de amostragem, dependendo da parte da planta, da variedade de copa e do nutriente estudado. 


\title{
EFFECT OF THE SUDDEN DEATH OF THE CITRUS ON THE NUTRITIONAL STATE OF THE VARIETIES PÊRA RIO AND NATAL IN THE LEMON TREE CRAVO
}

\author{
Author: LUCIANA BERTOLOTTI \\ Adviser: Prof. Dr. QUIRINO AUGUSTO DE CAMARGO CARMELLO
}

\section{SUMMARY}

The Brazilian culture of citrus is the greater of the world, it is one of the main cultures produced in Brazil, however it has been for 5 years suffering with the arrival of the sudden death in citrus, mainly in the south of the Triângulo Mineiro and north of São Paulo. With the objective to evaluate the nutritional condition of plants in levels of symptoms in the sudden death of citrus and making the accompaniment of the soil fertility soil in these areas with purpose of comparison of the efficiency nutrients absorption nutrients, two experiments in a commercial orchard situated in the city of Frutal - MG had been lead. Two varieties of citrus had been used, 'Pêra Rio' and 'Natal', on the lemon tree 'Cravo' both with 14 years. The experimental design was entirely randomized with four treatments (healthy plants and in three levels of sudden death) and four repetitions, in split plot in time. The plants with sudden death had been diagnosised by the visual symptoms. The assessments had begun in June, 24, 2003 and finished December, 13 of this year, and had been carried through regular intervals of 35 days. In each assessments the leaves, twigs, rind of the trunk and roots had been separate to determine the nutrients concentration were determined the nutritional 
content of the soil either. In the variety 'Pera Rio', the behavior of the nutrients had been the following ones: in leaves the concentrations of phosphorus, potassium, sulphur and boron had diminished with the advance of the illness, and zinc was increased. In the twigs the concentrations of nitrogen, phosphorus, potassium had diminished and of copper, iron, manganese and zinc had increased. In the rind of the trunk the iron and the manganese had diminished and finally in the roots the concentrations of nitrogen, calcium, sulphur, boron, iron and zinc had diminished. In the variety 'Natal', the behavior of the nutrients was a little different of 'Pêra Rio': in leaves the potassium concentration diminished with the advance of the illness. In the twigs the concentrations of nitrogen, phosphorus, potassium had diminished and manganese was increased. In the rind of the trunk the potassium and the boron had diminished and the magnesium and manganese had increased and finally in the roots the concentrations sulphur, boron and zinc had diminished. The soil didn't influence in the nutritionals alterations that had occurred with the plants, with the evolution of the illness the content had remained unchanged. The nutritional behavior revealed varied in sampling periods, depending of the plant part, pantry variety and nutrient studied. 


\section{INTRUDUÇÃO}

A produção da safra $2003 / 04$ foi de 345 milhões de caixas de $40,8 \mathrm{Kg}$, com uma produtividade média de 2,0 caixas por planta. No ano de 2003, o agronegócio da citricultura movimentou US $\$ 3,23$ bilhões, sendo responsável por $1,87 \%$ do total da pauta de exportação e $4,47 \%$ das vendas internacionais do setor agrícola, sendo assim, o desafio é conseguir-se manter essa meta, mesmo com essa doença crescendo cada vez mais (FNP, 2004).

O Estado de Minas Gerais, principalmente o Triângulo Mineiro, e o Norte do Estado de São Paulo vêm sofrendo com a Morte Súbita do Citros (MSC), que está dizimando todos os pomares da região que possuem como porta-enxerto o limoeiro 'Cravo' e o limoeiro 'Volkameriano'. A morte súbita, logo após a sua descoberta, era atribuída a diversos fatores, como a tristeza, o declínio, os distúrbios fisiológicos, as desordens nutricionais, ou até mesmo as doenças exóticas.

O tempo entre o aparecimento dos primeiros sintomas visuais e a morte das plantas é muito variável, podendo demorar meses e até anos, dependendo das condições do pomar e da época do ano, sendo que a evolução dos sintomas é mais rápida na primavera.

Diversos pesquisadores estão envolvidos na elucidação do problema, com abordagens que pretendem ampliar o conhecimento sobre a anomalia e propor estratégias de controle. A Alellyx Applied Genomics, laboratório de biotecnologia, com sede em Campinas (SP), anunciou a descoberta do inseto responsável pela transmissão do Citrus Sudden Death Virus (CSDV), que supostamente é o transmissor da Morte Súbita do Citrus (MSC). Os vetores do vírus seriam pulgões verde e cinza.

Já existem várias possibilidades de controle parcial, entre elas a poda, no entanto quando as árvores começam a brotar, os sintomas se desenvolvem novamente, devido à não recuperação do sistema radicular que está comprometido. 
Outra possibilidade é a subenxertia, além de, utilizar-se o interplantio de pomares de limoeiro 'Cravo' com árvores de porta-enxertos tolerantes.

Os pomares estão sendo formados em áreas novas, em busca de umidade e para se evitar contaminação pela Morte Súbita, numa migração lenta e perene da citricultura de São Paulo, Norte para o Sul do Estado.

De acordo com uma pesquisa realizada por Renato Beozzo Bassanezi da FUNDECITRUS, os pés de laranja com sintomas iniciais de MSC (nível 1) apresentam uma produção média, $30 \%$ menor que a das árvores sadias, e as com sintomas severos da doença (nivel 2), têm produção média $50 \%$ menor que as plantas sadias. Nos dois níveis de sintomas, houve redução do tamanho e do número de frutos por árvore, principalmente, em razão da idade. De uma maneira geral, a produtividade esperada de uma planta sadia é de 2,26 caixas por árvores (Fundecitrus, 2003c).

A morte súbita deve causar uma diminuição na eficiência de absorção e de translocação de nutrientes, fazendo com que a velocidade da doença aumente, pela redução da concentração desses. Assim, o presente trabalho teve como objetivo avaliar a evolução do estado nutricional de plantas nos diversos estágios de infecção da doença (sem sintoma, sintoma inicial, intermediário e final). Para isso foram coletadas amostras das folhas, dos galhos, da casca do tronco, das raizes e do solo, periodicamente, para fim de comparação de eficiência de absorção de nutrientes nos diversos estágios. 


\section{REVISÃO DE LITERATURA}

\subsection{Histórico da Morte Súbita do Citros}

Uma nova doença afetando laranjeiras-doces [C. sinensis (L.) Obs.] enxertadas em limoeiro 'Cravo' (C. limonia Obs.) foi observada pela primeira vez em 1999, no Sudoeste de Minas Gerais e no Norte de São Paulo (Fernandes \& Bassanezi, 2001; Müller et al., 2002).

Pesquisadores do Centro APTA Citros 'Sylvio Moreira' denominaram a doença de morte súbita do citros, em vista da rapidez com que as plantas sucumbem e rapidamente ela foi considerada o atual inimigo número um da citricultura (Centro de Citricultura Sylvio Moreira, 2001; Fundecitrus, 2002a).

Em dezembro de 1999, ela foi constatada no município de Comendador Gomes, Sul do Triângulo Mineiro, em um pomar de laranja 'Valência' enxertada sobre limoeiro 'Cravo'. Inicialmente a doença foi constatada em um talhão de 4.703 plantas, com espaçamento de 8,0 x 5,0 metros, plantado em 01/06/1988. Em dezembro de 1999 , foram eliminadas, neste talhão, 518 plantas mortas $(11,01 \%)$ devido à causa desconhecida. O problema teve inicio em reboleira, num canto do talhão. Nesse ano, a safra foi excepcional, mesmo com uma acentuada seca acentuada. Em agosto de 2000, foram identificadas 767 plantas doentes e 210 plantas mortas, totalizando 977 plantas $(20,76 \%)$. Essas plantas não foram eliminadas e realizou-se um novo levantamento nesse talhão em janeiro de 2001 revelou a existência de $86 \%$ de plantas doentes ou mortas, restando somente $14 \%$ de árvores assintomáticas, sendo toda a quadra erradicada (Fernandes \& Bassanezi, 2001). Em um talhão próximo, de idade semelhante, a incidência da doença elevou-se com uma distribuição aleatória, de $35 \%$ em fevereiro para $60 \%$ em maio de 2001 (Müller et al., 2002) 
Em Colômbia, no Norte do Estado de São Paulo, a constatação da doença ocorreu numa quadra de 14.000 árvores de 'Hamlim'/'Cravo', com 23 anos de idade cuja mortalidade das plantas foi de $30 \%$ no período de três anos. Neste caso, a doença progrediu em três círculos, um maior e dois menores (Müller et al., 2002).

A Fundecitrus fez um levantamento da dispersão da doença em fevereiro de 2002, e constatou a presença de MSC em 41 propriedades de sete municípios: Comendador Gomes, Frutal e Uberlândia, em Minas Gerais, e Altair, Barretos, Colômbia e Guaraci, em São Paulo (Fundecitrus, 2002).

Em um novo levantamento realizado entre os meses de junho e setembro de 2002, constatou-se a doença em cinco Municípios do Estado de Minas Gerais e São Paulo, além dos sete que já eram conhecidos. A doença estava presente em Campo Florido, Planura, Monte Alegre de Minas e Prata, em Minas Gerais; e Olimpia em São Paulo (Fundecitrus, 2002e). Foram encontradas cerca de 327,5 mil plantas com os sintomas da doença.

Nesse levantamento, pode-se constatar que em Minas Gerais existiam 93,3\% das plantas com MSC, concentradas principalmente em Comendador Gomes, Frutal e Uberlândia. Em São Paulo, o município de Colômbia tinha $70,9 \%$ dos talhões com a doença, mas com uma baixa incidência de plantas com sintomas $(1,4 \%$ das árvores por talhão contaminado). Mesmo assim o município era responsável por $96,5 \%$ das plantas com Morte Súbita do Estado de São Paulo. Os demais municipios paulistas onde a doença foi detectada em menos de $5 \%$ de talhões contaminados (Fundecitrus, 2002e).

O levantamento realizado pela Fundecitrus no final de 2003 possibilitou uma comparação do progresso da doença, que avançou $60 \mathrm{Km}$ em um ano. Em 2002, no Estado de São Paulo, cinco municipios tinham MSC e cerca de 22 mil plantas estavam afetadas. Em 2003, a doença foi constatada em 18 municipios paulistas e em mais de 44 mil plantas. Tendo um aumento significativo de área afetada de $2.816 \mathrm{~km}^{2}$ para $12.810 \mathrm{~km}^{2}$ (Fundecitrus, 2004a).

A presença da enfermidade se restringe à ponta mais setentrional do Estado, sendo que $30 \%$ do parque citricola paulista está a uma distância de $100 \mathrm{~km}$ dos focos de infecção (Pivetta, 2003).

A hipótese de que o porta-enxerto limoeiro 'Volkameriano' também não tolera a doença foi confirmada, essa suspeita apareceu em 2003, quando plantas enxertadas 
sobre esse porta-enxerto apresentaram sintomas de morte súbita na copa, nas raízes e na parte interna da casca. A dúvida persistiu, porque alguns pomares não manifestavam os sintomas, mesmo estando em áreas contaminadas. Uma das hipóteses levantadas é de que a doença tenha comportamento diferente no limoeiro 'Volkameriano', com tempo maior de incubação, de mais de três anos, e que o grau de severidade seja menor do que no limão 'Cravo' (Fundecitrus, 2004b).

As subenxertias vem sendo utilizadas com cavalinhos diferentes de limoeiro 'Cravo' ou 'Volkameriano', o que tem evitado a morte das plantas novas, que apresentavam os primeiros sintomas. As melhores alternativas testadas até agora são - citromeleiro 'Swingle' e as tangerineiras 'Cleópatra' e 'Sunki', em termos de desenvolvimento das plantas (Fundecitrus, 2002b). A tangerineira 'Cleópatra' tem ainda a vantagem de que, se for irrigada, compensa com a produtividade e a vida útil mais longa das plantas (Fundecitrus, 2002d).

Deve-se levar em conta a compatibilidade entre a copa e o porta-enxerto, existindo certas combinações que não dão certo, como por exemplo, a incompatibilidade entre o citromeleiro 'Swingle' e a copa de 'Pêra' (Fundecitrus, 2004c). A decisão de subenxertar deve levar em conta a idade e produtividade do pomar e a distância que o pomar está das áreas com MSC (Fundecitrus, 2003b).

Com o surgimento dessa doença, voltou-se a questionar sobre a diversidade de porta-enxertos em uma propriedade, sendo muito arriscado utilizar um único portaenxerto, devido ao aparecimento de outra nova doença ou praga (Fundecitrus, 2002d).

\subsection{Etiologia}

A doença tem um periodo de incubação de pelo menos dois anos, por isso há uma defasagem entre a infecção e a expressão dos sintomas, o que significa que devem existir árvores infectadas além da área onde se observam pés de laranja doentes (Fundecitrus, 2004a).

Os pesquisadores acreditavam, inicialmente, que a doença fosse causada por um organismo vivo (biótico), possivelmente um vírus, sendo que os sintomas da MSC lembravam o deperecimento rápido das plantas sobre porta-enxertos de laranja azeda (C. aurantium L.) causada pelo vírus da tristeza do citros (CTV), quando da introdução da virose no Brasil, no final da década de 30 (Müller et al., 2002). 
Durante as primeiras observações, surgiu a hipótese que estava direcionando todas as pesquisas, a possibilidade de que a morte súbita fosse uma mutação dos vírus da tristeza, doença que dizimou os pomares brasileiros nos anos 40 . Entre as semelhanças, está o fato de que ambas são doenças que atacam combinações de copa/porta-enxerto. Além disso, nos dois casos, o periodo para a expressão de sintomas, em $90 \%$ do talhão, é de dois a quatro anos (Fundecitrus, 2003a).

A rápida disseminação, o tipo de distribuição da doença nos talhões e a presença de plantas de limoeiro 'Cravo' sadias em talhōes afetados gravemente tornam difícil aceitar que a causa primária da doença seja qualquer fator abiótico Além disso, a distribuição espacial das árvores sintomáticas, a ausência de sintomas em bloco em pomares com baixa incidência, não indica tratar-se de um patógeno veiculado pelo solo (Fundecitrus, 2002).

Cerca de 30 pesquisadores de instituições brasileiras e do exterior, estão empenhados em confirmar o agente causal, seu modo de ação, modo de infecção, sendo também importante a avaliação dos danos provocados, como reduzí-los ou evitá-los. (Fundecitrus especial, 2002).

Devem ser levados em conta os fatores abióticos, como o ambiente através da alta temperatura, o estresse nutricional ou químico por acúmulo de compostos nocivos ou o estresse hídrico, que podem acelerar e/ou induzir os sintomas de MSC, pois a interação planta-patógeno só pode ser completa se o efeito do ambiente for considerado (Müller et al., 2002).

Alguns possíveis fatores bióticos que poderiam causar a MSC foram descartados por Müller et al (2002), como por exemplo, a origem da mudas, pois as mudas são originárias de viveiros de vários municípios: Araraquara, Bebedouro e Casa Branca (SP), e Prata (MG). Além disso, plantas "irmãs", levadas para outras regiões, deram origem a pomares que não apresentam a doença.

Outro fator biótico também descartado pelos mesmos autores é de que patógenos do solo sejam o agente causal. Foram efetuados em 2000, tratamentos para o controle de Phytophthora e Fusarium onde haviam plantas afetadas, sem nenhum efeito positivo. Além disso, não foi encontrada nenhuma correlação entre a MSC e as bactérias Xyllela e Xanthomonas que afetam o citros. 
A hipótese de que o agente causal seria um viróide foi afastada, pois acreditase que existe um vetor na transmissão e viróides são transmitidos por ferramentas infectadas e borbulhas (Müller \& Costa, 1980).

A empresa Alellyx Applied Genomics, anunciou a descoberta do inseto (vetor) responsável pela transmissão do Citrus Sudden Death Virus (CSDV) ou Vírus da Morte Súbita, novo tipo de vírus da familia Tymoviridae descoberto em 2003 pela empresa e que pode estar associado à Morte Súbita dos Citros (Fundecitrus, 2004b).

Segundo Ayres ${ }^{1}$, o vírus foi encontrado em pulgões coletados em áreas de ocorrência da doença, nas regiões Norte de São Paulo e Sul do Triângulo Mineiro. Embora o virus tenha sido encontrado nas três espécies de pulgões, cujos nomes são Toxoptera citricida, Aphis spiraecola e Aphis gossypii (conhecidos como pulgões preto, verde e cinza), apenas os dois Aphis são capazes de transmitir o virus para a planta. A investigação feita pelos pesquisadores da Alellyx descartou a transmissão pela cigarrinha.No entanto, não está totalmente comprovado que esse vírus é o agente causal.

$\mathrm{Na}$ opinião de Joseph Marie Bové, a doença pode ser causada pelo vírus Tymoviridae ou acontecer somente com a associação este e o vírus da tristeza, sendo assim, mais forte a hipótese de co-transmissão (Fundecitrus, 2004b).

\subsection{Sintomas da MSC}

A morte súbita foi constatada nas variedades Pêra Rio, Bahia, Natal, Hamlim, Valência, Valência Americana, Westin e Pineapple, de tangerineiras Cravo e Ponkan e de tangeleiros Orlando enxertados sobre limoeiro 'Cravo' ou enxertados sobre limoeiro 'Volkameriano' (Fundecitrus, 2002a).

Em laranjeiras enxertadas sobre tangerineiras Cleópatra e Sunki ou Citromeleiros Swingle, mesmo em blocos próximos a pomares contaminados severamente, a doença não se manifesta. Não foram constatados sintomas em plantas de pés francos de limoeiro 'Cravo', em locais com alta contaminação, indicando que somente a combinação da copa de laranja doce com o porta-enxerto de limoeiro 'Cravo' ou 'Volkameriano' que deixa a árvore vulnerável (Fundecitrus, 2002a).

\footnotetext{
${ }^{1}$ AYRES, A.J. Comunicação oral, 2004.
} 
Nos talhões com baixa incidência da doença, as plantas doentes se apresentam ao acaso, e naqueles com maior incidência ocorrem em pequenos agregados de plantas doentes dispersos pelo talhão, além de plantas doentes isoladas (Fernandes \& Bassanezi, 2001).

As árvores afetadas apresentam sintomas inicias como perda de brilho generalizado (semelhante ao declínio), com poucas brotações externas e sem brotações internas na copa, que contrasta com as plantas sadias, privadas de nutrientes e água - provavelmente em decorrência do entupimento generalizado do sistema de condução da seiva elaborada (floema) da copa para as raízes. Posteriormente ocorre desfolha parcial e morte da planta, o pé sintomático ainda dá uma safra de laranjas, cujo suco não é afetado pela enfermidade (Pivetta, 2003; Fundecitrus, 2002a). O sistema radicular apresenta grande quantidade de raízes mortas.

Na primavera e no início do verão, em variedades tardias (Natal e Valência), podem ser encontradas plantas mortas que apresentam frutos com peso e tamanho normais. Nessas plantas, houve tempo para o florescimento, o pegamento e a maturação, antes do colapso súbito da árvore. Segundo Renato Beozzo Bassanezi, pesquisador da Fundecitrus, a doença devia estar presente há algum tempo, mas aparentemente a morte acontece de forma rápida e súbita, quando a planta necessita absorver muita água para a emissão de novas brotações e o enchimento dos frutos e, como a planta não apresenta mais raizes para cumprir essas funções, ela entra em colapso. A doença pode chegar a esse estágio em poucas semanas após o surgimento dos primeiros sintomas, como foi observado em alguns pomares depois das chuvas (Fundecitrus, 2002; Fundecitrus, 2002a).

O sintoma característico é a presença de cor amarelada nos tecidos internos da casca do porta-enxerto, na região do floema funcional, contrastando com os tecidos da casca da copa que são brancos. Nas plantas com declínio não ocorre esse sintoma (Fernandes \& Bassanezi, 2001; Müller et al., 2002).

Para a diferenciação dos prejuízos, a MSC foi classificada em quatro níveis: zero (0), que representa árvores sadias ou aparentemente sadias; um (1), para indicar plantas com sintomas iniciais, ou seja, com perda de brilho e da coloração verdeescura das folhas; dois (2), para laranjeiras com sintomas severos, caracterizados pela 
desfolha parcial e com poucas brotações internas; e três (3), para indicar a morte da planta (Fundecitrus, 2003c).

O tempo para a manifestação dos sintomas varia de dois a quatro anos desde a identificação da doença no pomar, sendo que as árvores não morrem imediatamente. Passam pelos niveis de severidade, o que pode demorar algumas semanas ou alguns anos. Na maioria dos casos, menos de $15 \%$ das árvores do talhão morrem nos dois primeiros anos após a constatação da MSC. A maior parte das plantas fica entre os niveis 1 e 2 (Fundecitrus, 2003f).

O estudo da anatomia das plantas com sintomas de MSC foi realizado pelo Instituto Valenciano de Investigaciones Agrárias (IVIA), e pelo Núcleo de Apoio a Pesquisa em Microscopia Eletrônica da Escola Superior de Agricultura "Luiz de Queiroz" (NAP/Mepa - Esalq/USP), que mostrou o comportamento anormal das células dos vasos condutores de seiva (floema), evidente no engrossamento da casca na região de enxertia, ou seja, entre a copa e o cavalo. Para Joseph Marie Bové, o espessamento é uma reação da planta, que forma novos vasos de floema funcional para tentar substituir a necrose dos vasos, que ocorre em razão da doença. (Fundecitrus, 2004b).

Os primeiros exames feitos pelo Prof. Elliot W. Kitajima e sua equipe mostraram que ocorre, nas árvores doentes, um entupimento muito sério dos vasos do floema. Como conseqüência, os compostos elaborados pela fotossíntese nas folhas não chegam às raizes, que morrem "de fome". Também foram observadas alterações nas células na região do floema, em exames ao microscópio óptico, microscópio eletrônico de varredura e microscópio eletrônico de transmissão. Em algumas folhas das plantas com sintomas, foram encontradas alterações semelhantes às produzidas pelo vírus da tristeza dos citros no tecido do floema (Fundecitrus, 2002c).

\subsection{Nutrição Mineral de Citros}

Malavolta (1970) considerou que a deficiência da nutrição das plantas é devido às seguintes causas: insuficiência de nutrientes no solo; presença de nutrientes no solo, mas em formas não assimiláveis pelas raízes, desbalanceamento dos nutrientes no solo; danos físicos nas raizes, impedindo sua atividade normal de absorção; ocorrência de pragas e/ou doenças, tanto nas raízes como na parte aérea da planta, 
umidade excessiva ou seca no solo; aeração insuficiente na região de absorção das raízes, temperatura muito alta no solo e ma atmosfera; excesso ou falta de insolação e concorrência de outras plantas por nutrientes, água e luz.

O nitrogênio pode se absorvido na forma de íons nitrato e amônio, sendo transportado através do xilema e redistribuído, principalmente pelo floema; tanto o transporte quanto a redistribuição são relativamente rápidos. $O$ nitrogênio pode ser absorvido pelas plantas cítricas durante todo o ano, mas a maior taxa de absorção ocorre nos meses quentes. (Malavolta \& Violante Netto, 1989). Segundo Kampfer \& Uexkull (1966), o nitrogênio absorvido no outono e no inverno fica acumulado nas folhas e ramos até a primavera, quando é redistribuido, sendo usado, em grande parte, no florescimento e na frutificação. Quando o desenvolvimento vegetativo se inicia, os teores de $\mathrm{N}, \mathrm{P}$ e K das folhas tende a diminuir, devido, possivelmente, a saída desses nutrientes para os ramos e folhas novas, botões florais e frutos.

O nitrogênio presente na planta encontra-se em formas orgânicas, representadas, principalmente por aminoácidos e proteinas. Essas formas ocorrem na planta devido a um processo de redução assimilatória do nitrato, onde o $\mathrm{N}$ que estava com número de oxidação -5 passa para +3 , sendo, posteriormente, incorporado ao vegetal como constituinte da clorofila, das proteinas, dos aminoácidos, dos ácidos nucléicos, os alcalóides, das enzimas e dos outros compostos essenciais ao metabolismo das plantas (Malavolta \& Violante Netto, 1989 e Souza 1979).

De acordo com Malavolta (1979), os sintomas mais comuns de deficiência de nitrogênio são: a diminuição e, em casos extremos, a paralisação do crescimento vegetativo, a redução no número e tamanho de folhas, amarelecimento geral da folhagem, incluindo também as nervuras das folhas, a menor produção devido ao menor número e ao tamanho dos frutos, aos frutos apresentarem casca fina e coloração verde-pálida, a maturação precoce e pode ocorrer o secamento das extremidades dos ramos.

A quantidade de fósforo absorvida pelas plantas cítricas é pequena, quando comparada às de cálcio, nitrogênio e potássio. Ele é absorvido pelas raizes das plantas nas formas dos ânions fosfatos $\mathrm{H}_{2} \mathrm{PO}_{4} ; \mathrm{HPO}_{4}^{-2}, \mathrm{PO}_{4}^{-3}$, com preferência pela primeira. $\mathrm{A}$ absorção do $\mathrm{P}$ é fortemente influenciada pela concentração de $\mathrm{Mg}^{+2}$ no meio (Malavolta, 1970 e Marschner, 1997). 
Segundo Malavolta (1980), o fósforo absorvido na forma mineral é principalmente incorporado aos compostos orgânicos, sendo que 10 minutos depois da absorção, $80 \%$ do $\mathrm{P}$ pode ser encontrado como difosfato de uridina. No inverno, o frio reduz a absorção de fósforo, de modo que na primavera, ocorre uma considerável redistribuição desse elemento das folhas mais velhas na direção dos novos tecidos e órgãos, ainda em formação, na planta. A redistribuição do fósforo pelo floema é uma das mais rápidas, estando na forma de fosforilcolina.

O fósforo faz parte do ATP, da síntese de proteínas, da síntese e desdobramento de carboidratos e gorduras. Ele participa ainda da fotossíntese, da respiração, dos processos metabólicos da planta e da divisão celular. Ele é constituinte de algumas nucleoproteínas e dos ácidos nucléicos (RNA e DNA). E, é fundamental no armazenamento, no transporte e na utilização de energia pela planta (Epstein, 1975).

Segundo Rodriguez (1977), Malavolta \& Violante Netto (1989), os principais sintomas da deficiência de fósforo nas plantas citricas são: a redução e até a paralisação do crescimento vegetativo; as folhas com tamanho reduzido e coloração bronzeada sem brilho; em casos mais graves pode ocorrer o secamento das margens e pontas das folhas; a queda exagerada das folhas novas e botões florais; maior acidez e menor quantidade de suco; os frutos com casca mais espessa, menos lisa e de coloração mais intensa; a menor produção, a separação dos segmentos entre si e do eixo central, tornando o centro dos frutos oco e um teor de açúcares e de vitamina $\mathrm{C}$ maior.

O potássio absorvido pelas raízes é conduzido para a parte aérea através do xilema e também do floema; ele é incorporado na planta permanecendo na forma de $\mathrm{K}^{+}$, sua redistribuição interna pelo segundo sistema de vasos é rápida, freqüentemente o potássio das partes mais velhas é removido para os tecidos mais jovens da planta, sendo que $75 \%$ do potássio total da planta encontra-se no tecido na forma solúvel (Marschner, 1997). As concentrações de potássio, cálcio e magnésio na solução do solo devem ser balanceadas, pois o excesso de $\mathrm{Ca}$ elou $\mathrm{Mg}$ determina um menor aproveitamento do potássio, provavelmente devido à inibição não-competitiva (Malavolta, 1970).

A absorção máxima de potássio ocorre na primavera e no verão, quase cessando no inverno. Durante a maturação dos frutos, o teor foliar de potássio é reduzido em até $60 \%$, provavelmente devido à redistribuição do nutriente das folhas 
para os frutos e outros órgãos da planta (Malavolta \& Gomes 1960). O potássio é essencial para a produção de frutos, sendo o nutriente que mais influencia a qualidade dos mesmos (Trocme \& Gras, 1966).

O potássio não exerce influência sobre o crescimento. Sua função está ligada à fotossíntese e à formação de proteínas; à formação e transporte de açúcares; à diminuição da transpiração, à manutenção da turgescência das células e à ativação enzimática (Souza, 1979 e Malavolta, 1980).

Rodriguez (1977) descreveu os principais sintomas de deficiência de potássio como: tamanho menor das folhas das extremidades dos ramos; a coloração destas folhas é verde amarelado; com a lâmina ondulada e as pontas encurvadas; os frutos são pequenos, com casca lisa e fina; é comum o início de maturação anormal dos frutos a partir do pedúnculo, que pode secar; o mesmo podendo ocorrer com os ramos terminais. Em casos mais severos, as folhas apresentam áreas necróticas e caem, esgotadas pela migração do potássio para os frutos. Ocorre com freqüência a queda de frutos, com alguns ficando presos pelo pedúnculo. Em alguns casos, podem ocorrer rachaduras na casca e o surgimento de uma secreção gomosa.

$\mathrm{O}$ ion $\mathrm{Ca}^{+2}$ existente na solução do solo é a forma de absorção do cálcio pelas plantas, sendo esta absorção diminuída devido a altas concentrações de $\mathrm{K}^{+}$e de $\mathrm{Mg}^{+2}$ no meio, como também por muito $\mathrm{N}-\mathrm{NH}_{4}{ }^{+}$. A maior proporção do cálcio encontra-se em formas não solúveis em água, uma parte insolúvel está na parede celular, em células mais maduras o $\mathrm{Ca}$ pode estar na parede na forma de carbonato, oxalato, sulfato, fosfato, tartarato ou citrato (Malavolta, 1980, Marschner, 1997 e Dechen, 1983).

Mengel \& Kirkby (2001) relataram que o cálcio absorvido pelas raízes é translocado via xilema para as partes superiores das plantas junto com a corrente transpiratória. Portanto, a intensidade da transpiração controla, em grande parte a absorção e o transporte do $\mathrm{Ca}^{+2}$. Uma das principais funções do cálcio nas plantas é estrutural, como integrante da parede celular.

Os principais sintomas de deficiência de cálcio em citros descritos por Malavolta (1979) e Souza (1979) são: sistema radicular defeituoso e com poucas radicelas; redução no crescimento das plantas; clorose ao longo da nervura principal, nas margens e nas extremidades das folhas; em casos mais severos de carência ocorre a necrose das extremidades das folhas que caem prematuramente, seguindo-se da morte dos ramos do ápice para a base; a produção é reduzida; os frutos ficam 
pequenos, deformados e quase secos; pode ainda ocorrer uma floração intensa, seguida de uma grande queda de frutos jovens. $\mathrm{Na}$ falta de cálcio, a parte branca do fruto, ou seja, o albedo fica quebradiço e no seu eixo central aparece um vazio.

O magnésio é absorvido pelas raízes das plantas na forma iônica $\left(\mathrm{Mg}^{+2}\right)$, existente na solução do solo. A maior absorção de magnésio ocorre no verão, diminuindo com a seca e o frio que é o normal para a maioria dos nutrientes. $O$ transporte do magnésio na planta é semelhante ao do cálcio, pois ambos se movem para as partes superiores da planta através da corrente transpiratória. Ao contrário do cálcio, no entanto, o magnésio é móvel no floema e pode ser redistribuido das folhas mais velhas para as mais novas e frutos em desenvolvimento. (Dechen, 1983 e Malavolta \& Gomes 1960).

No tecido da planta, uma alta proporção do $\mathrm{Mg}$ total, geralmente da ordem de $70 \%$, é difusível e está associado com ânions minerais e orgânicos (malato e citrato) (Malavolta, 1980). Assim como o nitrogênio, é um nutriente essencial da clorofila, que possibilita a realização da fotossintese, da qual resultam os carboidratos (Souza, 1979).

Os principais sintomas de deficiência de magnésio nos citros descritos por Malavolta \& Prates (1994) são: a clorose das nervuras secundárias e, ao lado da nervura principal; em um estágio mais avançado de deficiência, a clorofila remanescente forma um " $\mathrm{V}$ " verde e invertido em relação ao pecíolo, sendo este um sintoma caracteristico da falta de magnésio. Com a migração contínua do nutriente, as folhas ficam cada vez mais amareladas e caem prematuramente. Os frutos são menores, com casca fina e com teores de açúcares, sólidos solúveis, acidez total e vitamina $C$ menores, apresentando uma coloração pálida tanto na casca quanto na polpa, sendo menos resistentes ao transporte.

A forma de enxofre absorvida predominantemente da solução do solo pelas raizes é a altamente oxidada - sulfato $\left(\mathrm{SO}_{4}{ }^{-2}\right)$. A sua maior proporção na planta é representada pela forma reduzida correspondente ao sulfeto $\left(S^{-2}\right)$, seguindo a incorporação do $S$ em compostos orgânicos. (Malavolta, 1980).

As folhas são capazes de absorver também o gás $\mathrm{SO}_{2}$ existente no ar, além do $\mathrm{SO}_{4}^{-2}$. As funções que 0 enxofre desempenha na vida da planta podem ser classificadas em dois grandes grupos: estruturais e metabólicos. Os compostos de enxofre desempenham um papel muito importante na estrutura das proteínas, 
possuindo também funções metabólicas, que são devidas aos aminoácidos em proteínas, aminoácidos livres e outros compostos de enxofre de baixo peso molecular (Malavolta, 1980). Os sintomas de deficiência, segundo Malavolta \& Prates (1994) são: folhas novas verde-amareladas, às vezes com nervuras verdes destacadas.

$\mathrm{O}$ boro é absorvido como $\mathrm{H}_{3} \mathrm{BO}_{3}$, mostrando um transporte unidirecional no xilema na corrente transpiratória e imobilidade no floema. O boro é o único nutriente da planta que não satisfaz o critério direto de essencialidade: até hoje não se encontrou um composto vital de que ele participe e nem se identificou qualquer reação crucial para o metabolismo, que deixa de ocorrer na sua ausência. Satisfaz, porém, o critério indireto, pois foi demonstrado que o boro influencia a atividade dos componentes específicos da membrana celular, aumentando a capacidade da raiz de absorver fósforo, cloro e potássio e a ATPase ativada por $\mathrm{KCl}$ mostra uma baixa atividade nas raizes das plantas deficientes em B (Malavolta \& Violante Netto, 1989 e Marschner, 1997).

Os sintomas de carência aparecem, primeiramente, nos órgãos mais novos e nas regiões de crescimento. A vegetação nova fica sem brilho, rala e com algumas folhas deformadas, às vezes com cortiça nas nervuras; os frutos ficam com muito albedo, apresentando goma perto da pele; a goma pode aparecer também nos lóculos; ocorre queda excessiva de frutos novos e sementes são abortadas (Malavolta \& Violante Netto 1989).

O cobre é absorvido como $\mathrm{Cu}^{+2}$ e está presente no xilema como o complexo do tipo [ânion - $\mathrm{Cu}$ ], o lhe que confere alta afinidade ao $\mathrm{N}$ do grupo amina dos aminoácidos. A função principal do cobre é a de ativador enzimático, mas também desempenha outras funções, como a síntese de proteínas, o metabolismo de carboidratos e a fixação simbiótica do $N_{2}$. (Marschner, 1997 e Malavolta, 1980).

Segundo Malavolta \& Violante Netto (1989), o cobre é considerado um elemento imóvel no floema, sendo assim, os sintomas de deficiência se mostram, em geral, nas folhas mais novas que, usualmente, ficam grandes e verde escuras. Os ramos ficam alongados e ondulados nos estádios iniciais; ocorrem bolhas com goma ao longo de ramos vigorosos na base de cada pecíolo; ocorrem gemas múltiplas ou novos brotos podem se formar nos nós.

O ferro é absorvido pelas raízes como $\mathrm{Fe}^{+2}$ e $\mathrm{Fe}^{+3}$ e, o seu transporte se dá na corrente transpiratória, sendo que esse nutriente aparece largamente na forma de 
quelato do ácido cítrico. As funções do ferro são: ativador enzimático, síntese de proteína e síntese da clorofila. A redistribuição do ferro nas plantas adultas é praticamente nula, como conseqüência, a lâmina foliar amarelece, enquanto as nervuras podem ficar verdes durante algum tempo, destacando-se como um reticulado fino. Em casos severos, as folhas podem ficar totalmente pálidas e com um tamanho reduzido (Marschner, 1997 e Malavolta \& Violante Netto, 1989).

O manganês é absorvido ativamente pela planta como $\mathrm{Mn}^{+2}$ e seu o transporte se dá através da corrente transpiratória e se faz na forma de $\mathrm{Mn}^{+2}$ (inorgânica). As funções do $\mathrm{Mn}^{+2}$ na planta são: ativador enzimático, papel indireto na síntese de proteinas e na multiplicação celular (devido à ativação da enzima polimerase do RNA), atuação na fotossíntese como doador de elétrons para a clorofila ativada e a síntese, a formação, a multiplicação e o funcionamento dos cloroplastos (Marschner, 1997 e Malavolta, 1980).

Segundo Malavolta (1980) e Malavolta \& Violante Netto (1989), ocorre uma pequena redistribuição do $\mathrm{Mn}$ absorvido, tendo como conseqüência desta redistribuição insuficiente, os sintomas de deficiência se manifestam nas folhas mais novas que, inicialmente, mostram um amarelecimento internerval, onde as nervuras e uma estreita faixa do tecido ao longo das mesmas permaneçam verdes (reticulado grosso).

O zinco é essencial para a síntese do triptofano, que por sua vez, é o precursor do ácido indolil acético que é um dos responsáveis pelo aumento do volume celular. As plantas deficientes em zinco mostram grande diminuição no nível de RNA, o que resulta na diminuição da síntese de proteína e da divisão celular. Além dessas funções o zinco é um ativador enzimático importante (Marschner, 1997).

Segundo Malavolta \& Violante Netto (1989) e Rodriguez (1991), a deficiência de zinco é induzida pelo fósforo quando em altos níveis no meio, os sintomas mais típicos da carência de zinco, que ocorrem nos órgãos novos, por ser um elemento de baixa redistribuição, consistem no encurtamento dos internódios e na produção de folhas novas, pequenas, cloróticas e lanceoladas; podendo aparecer tonalidades roxas no caule e nas folhas. Em plantas perenes, é comum a ocorrência da formação de um tufo de folhinhas na ponta dos ramos, além de frutos pequenos e pálidos. 


\subsection{Nutrição vs doenças cítricas}

A absorção de nutrientes pelos citros ocorre durante todo o ano. No entanto é maior no florescimento e na formação de folhas de ramos novos: setembro/dezembro e março/abril no hemisfério Sul (Kampfer et al., 1966).

Bassanezzi ${ }^{2}$ realizou análises de amostras de radicelas de plantas doentes e sadias e observou que os niveis de manganês $(\mathrm{Mn})$ e de zinco $(\mathrm{Zn})$ diminuíram, sendo que a concentração de $\mathrm{Mn}$ passou de $221.3 \mathrm{mg} \mathrm{kg}^{-1} \mathrm{em}$ plantas sadias para $53.2 \mathrm{mg}$ $\mathrm{kg}^{-1}$ em plantas doentes e de $\mathrm{Zn}$ de $356.1 \mathrm{mg} \mathrm{kg}^{-1}$ em plantas sadias para $220.9 \mathrm{mg}$ $\mathrm{kg}^{-1} \mathrm{em}$ plantas doentes. Nessas mesmas amostras, notou um aumento no nivel de magnésio $(\mathrm{Mg})$ de plantas doentes $\left(2.77 \mathrm{~g} \mathrm{~kg}^{-1}\right.$ contra $\left.2.06 \mathrm{~g} \mathrm{~kg}^{-1}\right)$. Essas análises de radicelas ainda não foram publicadas.

Smith (1966a) observou um efeito do $\mathrm{Mg}$ sobre o $\mathrm{Zn}$ e o Mn, isto é, o magnésio desloca o zinco e o manganês para a parte aérea, fazendo com que esses dois micronutrientes se acumulem nas folhas.

Em amostras de folhas, Leão ${ }^{3}$ observou que a concentração de silício (Si) era menor nas plantas doentes, sendo que nas plantas sadias a concentração era de 800 $\mathrm{mg} \mathrm{kg}^{-1} \mathrm{e}$ em plantas doentes era $600 \mathrm{mg} \mathrm{kg}^{-1}$. Machado observou também a queda do nitrogênio $(\mathrm{N})$ nas folhas.

O nitrogênio participa do crescimento e do aspecto verde na planta, além de afetar a produção e a qualidade dos frutos. É componente da clorofila, das proteínas, dos alcalóides, dos aminoácidos, dos amidos, das enzimas e outras substâncias. As formas nitrica, amídica (uréia) e amoniacal são absorvidas pelos citros (Smith, 1966b).

Machado ${ }^{4}$ também analisou a casca do tronco de plantas com e sem MSC, sugerindo que não houve diferenças significativas para os nutrientes: potássio, cálcio, magnésio, cobre, ferro e manganês, mas o teor de $\mathrm{Zn}$ foi maior nas plantas doentes.

Esses resultados nutricionais das plantas doentes ainda não foram publicados, por se tratar de um assunto muito recente. Nenhum estudo mais detalhado, tentando correlacionar a MSC com aspectos da Fertilidade do Solo ou mesmo de caracterização nutricional das plantas doentes tinha ainda sido realizado.

\footnotetext{
${ }^{2}$ BASSANEZI, R.B. Comunicação pessoal, 2003.

${ }^{3}$ LEÃO, H.C. Comunicação pessoal, 2003.

${ }^{4}$ MACHADO, M.A. Comunicação pessoal, 2003.
} 
Mayo ${ }^{5}$ realizou experimentos com a aplicação de boro em plantas com MSC, e os resultados não foram positivos, as plantas deficientes nesse nutriente apresentam desenvolvimento reduzido, sendo que as folhas se tornam menores, com nervuras salientes e muitas vezes corticosas. Nas plantas em produção, ocorre uma grande queda de frutos novos. Quanto aos frutos, estes se tornam duros, e com albedo espesso e tamanho reduzido, apresentam-se deformados e podem aparecer manchas de goma escura no albedo e no centro, o suco é reduzido e as sementes são pequenas, escuras, mal formadas e envoltas em goma (Rodriguez, 1991).

O componente ambiental não deve ser descartado, enquanto a doença não ocorrer em solos mais férteis e sem déficit hídrico. $O$ ambiente e as condições de solo e de manejo devem ter importância na intensidade e na velocidade de manifestação dos sintomas de MSC, mas a atribuição deles como causa primária da doença está, de acordo com vários especialistas, praticamente excluida (Muller et al., 2002).

Bassanezzi ${ }^{6}$ observou também que o solo ao redor de plantas com MSC apresentava níveis mais altos de $\mathrm{Ca}$ e $\mathrm{Mg}$ que aquele ao redor das plantas sadias. Foram utilizadas plantas de Pêra Rio/L. 'Cravo' sadias que apresentavam $17 \mathrm{mmol}_{\mathrm{c}}$ $\mathrm{dm}^{-3}$ de Ca e $5 \mathrm{mmol}_{\mathrm{c}} \mathrm{dm}^{-3}$ de $\mathrm{Mg}$; plantas de Pêra Rio/L. 'Cravo' doentes que apresentavam $29 \mathrm{mmol}_{\mathrm{c}} \mathrm{dm}^{-3}$ de Ca e $9 \mathrm{mmol}_{\mathrm{c}} \mathrm{dm}^{-3}$ de $\mathrm{Mg}$ e plantas de Pêra Rio/Cleópatra sadias que apresentavam $29 \mathrm{mmol}_{\mathrm{c}} \mathrm{dm}^{-3}$ de Ca e $9 \mathrm{mmol}_{\mathrm{c}} \mathrm{dm}^{-3} \mathrm{de} \mathrm{Mg}$ (extrator $\mathrm{KCl} 1 \mathrm{~N}$ ). Sabe-se que o excesso de calcário pode levar à deficiência de $\mathrm{B}$, que causa interferência na elongação celular e afeta o transporte de carboidrato.

Quanto a outras doenças dos citros, pode-se destacar o Declínio, sendo que uma de suas características é o acúmulo de zinco e fenóis no tronco, enquanto as plantas sadias, com Tristeza ou com Gomose não apresentam esse acúmulo (Albrigo \& Young, 1979).

Wutscher (1981) não observou diferenças no solo sob as plantas sadias e com declínio, para os nutrientes potássio, cálcio, magnésio e sódio, nem entre os ions sulfato e cloreto. Quando consideradas em conjunto, as quantidades de cátions não diferiram entre os solos, no entanto o nivel dos ânions foi maior nos solos sob as plantas com Declínio.

\footnotetext{
${ }^{5}$ MAYO, J.C. Comunicação pessoal, 2003.

${ }^{6}$ BASSANEZI, R.B. Comunicação pessoal, 2003.
} 
Existe maior ocorrência do Declínio em solos rasos e sujeitos a "stress" de umidade ou drenagem desfavorável (Lyons \& Rouse, 1979). Isso também ocorre com a Morte Súbita, pois a doença se concentra no Norte de São Paulo e Sul do Triângulo Mineiro, onde o "stress" hídrico é alto.

Quanto aos niveis de nutrientes no floema do tronco, foram observados aumentos nas concentrações de zinco e manganês durante a evolução da doença (Willians \& Albrigo, 1984).

Em trabalho realizado na Flórida, foi medida a concentração de macro e micronutrientes no tecido foliar de plantas sadias e com Declínio. Nas plantas doentes, o teor de potássio foi mais baixo de que nas sadias e os teores de alumínio, cloro, cobre, sódio e zinco mais altos (Wurscher \& Hardesty, 1979).

Em outro trabalho realizado por Wutscher \& McDonald (1986), também foram analisadas as concentrações de macro e micronutrientes no tecido foliar, mostrando níveis maiores de magnésio, enxofre, cloro e manganês nas plantas com Declínio.

No Brasil, também foi realizado um trabalho com diagnose foliar e plantas com Declinio e sadias, sendo que as concentrações de nitrogênio, fósforo e potássio foram maiores na plantas sadias, ocorrendo o contrário para cálcio, boro, cobre e manganês. Sendo que o potássio foi o nutriente que mais caracterizou a doença, observando-se as diferenças mais marcantes (Coelho et al., 1983).

Foram comparadas plantas sadias em estágios de Declínio: Estágio 1 - Prédeclínio (acúmulo de zinco no lenho, sem sintomas visuais) e Estágio 2 - plantas com sintomas iniciais. As plantas no estágio 2 apresentaram maior nivel de nitrogênio, quando comparado com as sadias (Albrigo et al., 1986).

Tavares (1987) também realizou experimento comparando plantas sadias com estágios de Declinio: estágio 1 - folhas verde fosco; estágio 2 - desfolhamento e poucas brotações novas; estágio 3 - seca dos ramos ponteiros e estágio 4 - brotações no tronco da copa e do porta-enxerto. Foram observadas concentrações maiores de nitrogênio, potássio, magnésio e manganês nas plantas sadias, a concentração de magnésio diminuiu com a evolução da doença, sendo o nutriente que mais respondeu a essa evolução.

Avaliou-se os teores de macro e micronutrientes em laranjeiras 'Pêra' enxertadas sobre limão 'Cravo', em função da presença ou não dos sintomas de clorose variegada dos citros (CVC), sendo relacionados os seguintes estágios: plantas 
sadias, estágio 1 - plantas com um ano de doença, apresentando apenas sintomas foliares, estágio 2 - plantas com dois ou mais anos, com redução do tamanho dos frutos. Observou-se que as plantas com sintomas de CVC apresentaram teores inferiores de $\mathrm{N}, \mathrm{K}, \mathrm{Ca}$ e $\mathrm{Mg}$ em relação às sadias. $\mathrm{E}$ os teores de $\mathrm{Fe}$ e $\mathrm{Mn}$ foram superiores aos encontrados nas plantas sadias (Ricci et al., 2001) 


\section{MATERIAL E MÉTODOS}

\subsection{Localização da área experimental, variedade, estado nutricional.}

O experimento foi desenvolvido na Fazenda Portal de Minas, da Empresa Agrocitrus/Cargill, situada na cidade de Frutal, no Triângulo Mineiro, com temperatura média anual de $25,2^{\circ} \mathrm{C}$ e com precipitação de $427 \mathrm{~mm}$ anual,

As variedades utilizadas foram, Pêra Rio e Natal, ambas sobre o porta-enxerto limão 'Cravo', que vem sendo susceptível à Morte Súbita do Citros. A variedade Natal foi plantada em outubro de 1990, em um talhão com área de 19,96 ha. O espaçamento é de $8,0 \mathrm{~m}$ entre linhas e $5,0 \mathrm{~m}$ entre plantas. Já foram realizados na área 267 replantes. Esse talhão possui irrigação e uma produção média de $4.277 \mathrm{~kg} \mathrm{ha}^{-1}$. A variedade Pêra Rio foi plantada em dezembro de 1990, em um talhão com área de 12,68 ha. O espaçamento é de 7,0 m entrelinhas e 3,5 m entre plantas. Já foram realizados na área 289 replantes. Esse talhão possui irrigação e uma produção média de $3.843 \mathrm{~kg} \mathrm{ha}^{-1}$.

Para a diferenciação dos prejuízos, a MSC foi então classificada em quatro níveis: zero (0), que representa árvores sadias ou aparentemente sadias; um (1), para indicar plantas com sintomas iniciais, ou seja, com perda de brilho e da coloração verde-escura das folhas; dois (2), para laranjeiras com sintomas severos, caracterizados pela desfolha parcial e com poucas brotações internas; e três (3), para indicar a morte da planta (Fundecitrus, 2003c).

As coletas foram realizadas no periodo de 24 de julho a 13 de dezembro de 2003, em solo classificado como LATOSSOLO VERMELHO EUTROFÉRRICO TÍPICO (Embrapa, 1999). 
Tabela 1. Médias de teores de macronutrientes dos estágios da morte súbita e características químicas do solo da área experimental ${ }^{\left({ }^{*}\right)}$.

\begin{tabular}{lcccccccc}
\hline Variedades & pH & $\begin{array}{c}\text { Al } \\
\mathrm{mmolc} / \mathrm{dm}^{3}\end{array}$ & $\begin{array}{c}\text { MO } \\
\mathrm{g} / \mathrm{dm}^{3}\end{array}$ & $\begin{array}{c}\text { S } \\
-\cdots--m g / L-\end{array}$ & $\mathbf{P}$ & $\mathbf{C a}$ & $\mathbf{M g}$ & $\mathbf{K}$ \\
\hline Pêra Rio & 5,36 & 0,71 & 19,43 & 11,56 & 39,78 & 42,78 & 8,33 & 2,56 \\
Natal & 5,23 & 0,78 & 25,06 & 17,98 & 23,64 & 46 & 12,94 & 1,44 \\
\hline
\end{tabular}

") profundidade de amostragem : 0-20 cm.

$\mathrm{pH}-\mathrm{CaCl}_{2} 0,01 \mathrm{~mol} \mathrm{~L}^{-1}$ (Raij et al., 2001).

M.O. - Matéria orgânica, método colorimétrico (Raij et al., 2001).

$P$ - Extração por resina trocadora de ions e determinação por colorimetria (Raij et al., 2001).

$\mathrm{S}-\mathrm{NH}_{4} \mathrm{OAC} 0,5 \mathrm{~N}$ em HOAC $0,25 \mathrm{~N}$ (Vitti, 1989).

K-Extração por resina trocadora de íons e determinação por fotometria de chama (Raij et al., 2001).

$\mathrm{Ca}$ e $\mathrm{Mg}$ - Extração por resina trocadora de íns e determinação por espectrometria de absorção atômica (Raij et al., 2001).

$\mathrm{H}+\mathrm{Al}$ - Determinação por potenciometria em solução tampão SMP (Raij et al., 2001).

$\mathrm{Al}-\mathrm{KCl} 1 \mathrm{~N}$

Tabela 2. Média dos teores de micronutrientes dos estágios da morte súbita no solo da área experimental ${ }^{(*)}$

\begin{tabular}{|c|c|c|c|c|c|}
\hline Variedades & B & $\mathrm{Cu}$ & $\mathrm{Fe}$ & $M n$ & $\mathrm{Zn}$ \\
\hline & $\cdots$ & & $\ldots \mathrm{mg} / \mathrm{L}$ & 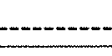 & $\cdots$ \\
\hline Pêra Rio & 0,55 & 5,47 & 14,48 & 24,27 & 3,36 \\
\hline Natal & 0,53 & 6,56 & 21,44 & 23,14 & 3,25 \\
\hline
\end{tabular}

") profundidade de amostragem : 0-20 cm.

$\mathrm{B}-\mathrm{BaCl}_{2} .2 \mathrm{H}_{2} \mathrm{O} 0,125 \%$ microondas (Raij et al., 2001).

$\mathrm{Cu}, \mathrm{Fe}, \mathrm{Mn}, \mathrm{Zn}$ - DTPA-TEA pH 7,3 (Raij et al., 2001).

Juntamente com a primeira análise de solo foram realizadas também análises foliares nas plantas nos estágios da morte súbita do citros. Os resultados podem ser observados na tabela 3 . 
Tabela 3. Teores médios foliares de macro e micronutrientes no início do experimento nas diversas fases da MSC

\begin{tabular}{|c|c|c|c|c|c|c|c|c|c|c|c|}
\hline \multirow[t]{2}{*}{ Varie } & $\mathbf{N}$ & $\mathbf{P}$ & K & $\mathrm{Ca}$ & Mg & $\mathbf{S}$ & B & $\mathrm{Cu}$ & $\mathrm{Fe}$ & Mn & $\mathrm{Zn}$ \\
\hline & & & & & & & \multicolumn{5}{|c|}{$\mathrm{mg} / \mathrm{kg}$} \\
\hline & & & & & & & & & & & \\
\hline & & & & & & & & & & & \\
\hline \multicolumn{12}{|c|}{ N-Digestão sulfúrica e determinação pelo método semi-micro Kjeldahl (Malavolta et al., 1997). } \\
\hline \multicolumn{12}{|c|}{ P - Digestão nítrico-perclórica e determinação por colorimetria (Malavolta et al., 1997). } \\
\hline \multicolumn{12}{|c|}{ K - Digestão nítrico-perclórica e determinação por fotometria de chama (Malavolta et al., 1997). } \\
\hline \multirow{2}{*}{\multicolumn{12}{|c|}{$\begin{array}{l}\mathrm{Ca}, \mathrm{Mg}, \mathrm{Cu}, \mathrm{Fe}, \mathrm{Mn}, \mathrm{Zn} \text { - Extração nítrico-perclórica e determinação por espectrometria de absorção } \\
\text { (Malavolta et al., 1997). }\end{array}$}} \\
\hline & & & & & & & & & & & \\
\hline \multicolumn{12}{|c|}{ S - Digestão nitrico-perclórica e determinação por turbidimetria do sulfato de bário (Malavolta et al., 1997). } \\
\hline \multicolumn{12}{|c|}{ 1997). } \\
\hline
\end{tabular}

\subsection{Adubação realizada no período do experimento}

Durante a realização do experimento foram feitas adubações na área, por se tratar de talhões comerciais.

Durante o experimento, na variedade Natal foram aplicados nutrientes apenas antes da última coleta. Foram adicionados no dia 21 de novembro: $135 \mathrm{~g}$ de $\mathrm{N} / \mathrm{planta}$, $135 \mathrm{~g}$ de $\mathrm{P} /$ planta, $67,5 \mathrm{~g}$ de $\mathrm{K} /$ planta e $2,25 \mathrm{~g}$ de $\mathrm{B} / \mathrm{planta}$.

$\mathrm{Na}$ Variedade Pêra Rio a adubação também antecedeu a última coleta sendo realizada no dia 10 de novembro: $128 \mathrm{~g}$ de $\mathrm{N} /$ planta.

Quanto à adubação foliar, na variedade Natal foi realizada somente uma vez, no dia 28 de outubro, antecedendo as duas últimas coletas, totalizando as seguintes quantidades de nutrientes: $2,6 \mathrm{~g}$ de $\mathrm{N} /$ planta; $0,52 \mathrm{~g}$ de $\mathrm{Mg} /$ planta de $\mathrm{Mg} ; 1,03 \mathrm{~g}$ de $\mathrm{Zn}$ /planta; $1,03 \mathrm{~g}$ de $\mathrm{Mn} /$ planta e $0,13 \mathrm{~g}$ de B /planta.

Na variedade Pêra Rio, foi realizada uma vez durante o experimento, no dia 13 de setembro, antecedendo as três últimas coletas, totalizando as seguintes quantidades de nutrientes: $1,6 \mathrm{~g}$ de $\mathrm{N}$ por planta; $0,32 \mathrm{~g}$ de $\mathrm{Mg}$ por planta; $0,63 \mathrm{~g}$ de $\mathrm{Zn}$ por planta; $0,63 \mathrm{~g}$ de Mn por planta e 0,08 $\mathrm{g}$ de $\mathrm{B}$ por planta.

\subsection{Delineamento experimental}

Utilizou-se o delineamento inteiramente casualizado, com quatro repetições, sendo dispostos em parcelas subdivididas no tempo, correspondendo a quatro 
estágios de sintomatologia da doença e cinco épocas de coleta, totalizando 80 unidades experimentais, sendo que as coletas foram feitas sempre na mesma planta e as duas variedades foram avaliadas separadamente.

\subsection{Tratamentos}

Foram utilizadas plantas em todos os estágios de sintomatologia da MSC:

1. Sem sintomas (nivel 0 ), que representa árvores sadias ou aparentemente sadias,

2. Sintomas iniciais (nível 1), com perda de brilho e da coloração verdeescura das folhas

3. Sintomas severos (nível 2), caracterizados pela desfolha parcial e com poucas brotações internas

4. Plantas mortas (nível 3).

\subsection{Amostragem das diversas partes da planta}

Foram realizadas cinco coletas de partes da planta amostradas sendo: folhas, ramos, radicelas e casca de tronco, em intervalos regulares (35 dias), para caracterizar as conseqüências nutricionais da doença. As plantas foram selecionadas ao acaso, no mesmo talhão, em área homogênea, com a mesma idade, para que os fatores solo, clima e planta não influíssem nos resultados.

As coletas das folhas recém-maduras foram realizadas na altura mediana da copa, sendo a terceira ou quarta folha de galhos que possuem frutos. Foram 16 folhas por planta, quatro a cada exposição (norte, sul, leste e oeste).

A coleta de folhas danificadas foi evitada. As amostras foram para Piracicaba dentro de sacos de papel identificados, em caixas de isopor, para a diminuição do metabolismo das mesmas.

Ao chegar em Piracicaba, as amostras foram limpas, para serem retiradas a impurezas da superficie das folhas, esta limpeza foi feita com água deionizada. Após a limpeza, as amostras foram secas à sombra, e depois colocadas em estufas com temperatura controlada a $65-70^{\circ} \mathrm{C}$, até atingir massa constante. Em seguida, as amostras foram moídas em moinho do tipo Wiley, para análise posterior. 
Os ramos foram coletados do mesmo local que as folhas. A casca do tronco foi retirada da parte da copa, sem danificar o tronco, para que se pudessem fazer coletas posteriores. As radicelas foram coletadas na projeção da copa, na faixa de adubação. Os ramos, as cascas e as radicelas coletados seguiram o mesmo procedimento realizado para as folhas, quanto ao transporte, limpeza, secagem e armazenamento.

\subsection{Amostragem do solo}

Para fins de avaliar a fertilidade do solo, foram feitas também coletas de solo, que foi retirado juntamente com as raizes, com amostradores nos quatro quadrantes na projeção da copa e numa profundidade de $0-20 \mathrm{~cm}$.

As amostras foram acondicionadas em sacos plásticos identificadas e encaminhadas para o laboratório, onde foram secas com estufa de circulação forçada e com temperatura não superior a $40^{\circ} \mathrm{C}$, e posteriormente peneiradas.

\subsection{Determinações químicas nas amostras de planta e solo}

A análise das concentrações dos nutrientes nas amostras de planta foi feita conforme a metodologia descrita por Sarruge \& Haag (1974) e Malavolta et al. (1997). Para a extração do nitrogênio a amostra foi submetida à digestão sulfúrica, e o nutriente foi determinado pelo método semi-micro Kjeldahl, através de destilação e posterior titulação com ácido sulfúrico.

A digestão nítrico-perclórica foi utilizada na preparação do extrato a partir do qual foram determinados os outros nutrientes. Os micronutrientes ferro, zinco, manganês e cobre foram determinados no extrato por espectrometria de absorção atômica, o fósforo foi determinado pelo método colorimétrico, o potássio pelo método de fotometria de chama, o cálcio e magnésio, após a diluição também foram determinados por espectrometria de absorção atômica e o enxofre foi determinado por turbidimetria de sulfato de bário

Quanto ao solo, a extração de cálcio, magnésio, fósforo e potássio foi feita pelo método da resina trocadora de íns. A determinação do $\mathrm{Ca}$ e $\mathrm{Mg}$ foi feita por espectrometria de absorção atômica, o $\mathrm{P}$ por colorimetria e $\circ \mathrm{K}$ por fotometria de chama (Raij et al., 2001). 
O enxofre foi extraido com $\mathrm{NH}_{4} \mathrm{OAc} 0,5 \mathrm{~N}$ em HOAc $0,25 \mathrm{~N}$ (Vitti, 1989). $\mathrm{O} \mathrm{H}+\mathrm{Al}$ foi determinado por potenciometria em solução tampão SMP e o alumínio foi extraído com $\mathrm{KCl} 1 \mathrm{~N}$, para o cobre, manganês, ferro e zinco será utilizado o extrator DTPA TEA a pH 7,3, a extração de boro será foi feita com $\mathrm{BaCl}_{2} \cdot 2 \mathrm{H}_{2} \mathrm{O} \quad 0,125 \%$ em microondas. $\mathrm{O} \mathrm{pH}$ foi determinado com $\mathrm{CaCl}_{2} 0,01 \mathrm{~mol} \mathrm{~L}^{-1}$ e a matéria orgânica pelo método colorimétrico (Raij et al., 2001).

\subsection{Análise estatística}

Todos os resultados receberam o tratamento estatístico recomendado, comparando as concentrações dos nutrientes e os graus de sintomatologia da doença com o passar do tempo através do emprego do "Statistical Analysis System" (SASWindows, 1989). Foi realizado o teste $F$ da análise da variância e, posteriormente o teste de Tukey, ao nivel de $5 \%$ de probabilidade. Se a interação tempo e tratamento for significativa foi realizado um desdobramento do mesmo. 


\section{RESULTADOS E DISCUSSÃO}

\subsection{Variedade Pêra Rio}

Para a avaliação das concentrações de macro e micronutrientes na variedade Pêra Rio, os resultados foram agrupados de três modos. O primeiro foi o agrupamento por estágio de sintomatologia, onde as coletas foram divididas segundo cada estágio; a segunda maneira foi por época de coleta e neste caso os estágios foram agrupados dentro de cada coleta, para que se pudesse avaliar o comportamento do nutriente dentro da planta com o passar do tempo, independente dos estágios de sintomatologia. $\mathrm{Na}$ terceira análise, foi avaliada a interação, quando existente, entre as épocas de coleta e os estágios de sintomas da morte súbita do citros, fazendo-se assim o desdobramento das duas primeiras.

\subsubsection{Nitrogênio}

Ao se analisar a concentração de nitrogênio dentro dos estágios de sintomatologia da morte súbita, pode-se notar diferenças do nutriente nos galhos e raízes (Tabela 4 ).

Tabela 4. Concentrações de nitrogênio em plantas de citros, variedade Pêra Rio, nos estágios da morte súbita do citros

\begin{tabular}{|c|c|c|c|c|}
\hline \multirow[t]{2}{*}{ Sintomas } & Folhas & Galhos & Casca do tronco & Raízes \\
\hline & \multicolumn{4}{|l|}{$\ldots$} \\
\hline 0 & 24,08 a & $10,13 a$ & 12,32 a & $12,71 \quad a$ \\
\hline 1 & $22,83 a$ & $8,44 a b$ & $11,69 a$ & $9,21 \mathrm{~b}$ \\
\hline 2 & 21,46 a & $7,76 \mathrm{~b}$ & 11,55 a & 11,21 ab \\
\hline 3 & $20,82 a$ & $9,23 a b$ & 13,53 a & 10,31 ab \\
\hline
\end{tabular}


À medida que os sintomas evoluíram, as concentrações de nitrogênio diminuíram nos galhos e raízes, mostrando assim, uma diferenciação do nutriente na comparação entre plantas assintomáticas e sintomáticas. Nos galhos, o nitrogênio caiu de $10,13 \mathrm{~g} \mathrm{~kg}^{-1}$ nas plantas assintomáticas para $8,44 \mathrm{~g} \mathrm{~kg}^{-1}$ nas plantas que estavam no primeiro estágio. A concentração ideal no nutriente nos ramos segundo Chapman (1968) é de $7,20 \mathrm{~g} \mathrm{~kg}^{-1}$, sendo assim, mesmo com a redução na concentração do nutriente, o nivel do mesmo não ficou deficiente.

A queda no nivel nutricional ocorrida nos galhos foi, provavelmente, reflexo da mesma queda, ocorrida nas raízes, em que as concentrações passaram de $12,71 \mathrm{~g} \mathrm{~kg}$ · 1 nas plantas assintomáticas para $9,21 \mathrm{~g} \mathrm{~kg}^{-1}$ nas plantas no primeiro estágio de manifestação da doença, sendo considerados deficientes, em ambos os estágios, pois a concentração ideal é de $19,50 \mathrm{~g} \mathrm{~kg}^{-1}$ (Chapman, 1968). As concentrações do nutriente na casca do tronco também são consideradas deficientes, segundo Chapman (1968), que seria de $16,40 \mathrm{~g} \mathrm{~kg}^{-1}$.

Não houve alteração na concentração de nitrogênio foliar, com o desenvolvimento da morte súbita, no entanto foi detectada uma queda na concentração de nitrogênio em plantas cítricas afetadas com declínio (Coelho et al.,1983 e Tavares, 1987). No caso da clorose variegada do citros a concentração de nitrogênio também caiu, com a evolução da doença (Ricci et al., 2001).

Segundo Violante Netto et al. (1988) e Rodrigues et al. (1991), a concentração de nitrogênio considerada adequada, nas folhas de citros geradas na primavera, com seis meses de idade, de ramos com fruto é de $23,00-27,00 \mathrm{~g} \mathrm{~kg}^{-1}$, que quando se comparada com a média das coletas realizadas de $22,30 \mathrm{~g} \mathrm{~kg}^{-1}$ e das plantas assintomáticas que apresentaram uma concentração média de $24,08 \mathrm{~g} \mathrm{~kg}^{-1}$, mostrando valor um pouco abaixo na média geral e adequado nas plantas assintomáticas. Considerando-se concentração adequada para a época de coleta do experimento de 20,00 a 25,00 $\mathrm{g} \mathrm{kg}^{-1}$ (Malavolta \& Prates, 1994), os valores continuaram adequados.

Quanto às épocas de coleta, verificou-se que os galhos, casca do tronco e as raizes tiveram alterações (Tabela 5). 
Tabela 5. Concentrações de nitrogênio em plantas de citros, variedade Pêra Rio, nas épocas de coleta

\begin{tabular}{cccccc}
\hline Coletas & Folhas & Galhos & $\begin{array}{c}\text { Casca do tronco } \\
\end{array}$ & Raizes \\
\hline 24 junho & $22,76 \mathrm{a}$ & $10,46 \mathrm{a}$ & $13,10 \mathrm{a}$ & $11,19 \mathrm{a}$ \\
29 agosto & $22,70 \mathrm{a}$ & $8,87 \mathrm{ab}$ & $11,10 \mathrm{bc}$ & $9,40 \mathrm{ab}$ \\
3 outubro & $22,02 \mathrm{a}$ & $8,78 \mathrm{~b}$ & $11,21 \mathrm{bc}$ & $9,81 \mathrm{a}$ \\
8 novembro & $22,94 \mathrm{a}$ & $9,90 \mathrm{ab}$ & $12,13 \mathrm{ab}$ & $9,81 \mathrm{ab}$ \\
13 dezembro & $22,70 \mathrm{a}$ & $7,01 \mathrm{c}$ & $10,49 \mathrm{c}$ & $7,32 \mathrm{~b}$ \\
\hline
\end{tabular}

As concentrações de nitrogênio na ultima coleta, nos galhos, casca do tronco e raizes foram afetados, ocorrendo uma diminuição nos valores. Nos galhos a concentração de nitrogênio passou de $10,46 \mathrm{~g} \mathrm{~kg}^{-1}$ na primeira coleta para $7,01 \mathrm{~g} \mathrm{~kg}^{-1}$ na última coleta, a mesma tendência ocorreu na casca do tronco onde a o nutriente passou de $13,10 \mathrm{~g} \mathrm{~kg}^{-1}$ na primeira coleta para $10,49 \mathrm{~g} \mathrm{~kg}^{-1}$ na última coleta. Nas raizes esse nutriente passou de $11,19 \mathrm{~g} \mathrm{~kg}^{-1}$ na primeira coleta para $7,32 \mathrm{~g} \mathrm{~kg}^{-1}$ na quinta coleta. Essa diminuição pode ser devido à migração do elemento no momento do florescimento que ocorreu durante as amostragens (Castro et al., 2001), as concentrações das folhas, no entanto, permaneceram inalteradas. Apesar de ter ocorrido aplicação de nitrato de amônio antes da última coleta, não houve tempo suficiente para que este fosse absorvido e incorporado na planta.

\subsubsection{Fósforo}

Analisando-se a concentração de fósforo dentro dos estágios de sintomatologia da morte súbita do citros, podem ser notadas diferenças do nutriente nas folhas e galhos (Tabela 6).

Tabela 6. Concentrações de fósforo em plantas de citros, variedade Pêra Rio, e no solo nos estágios da morte súbita do citros

\begin{tabular}{cccccccc}
\hline Sintomas & Folhas & Galhos & $\begin{array}{c}\text { Casca do tronco } \\
\text { Raizes }\end{array}$ & $\begin{array}{r}\text { Solo } \\
\mathrm{mg} \mathrm{dm}^{-3}\end{array}$ \\
\hline 0 & $1,51 \mathrm{a}$ & $0,68 \mathrm{a}$ & $0,61 \mathrm{a}$ & $0,84 \mathrm{a}$ & 52,22 & $\mathrm{a}$ \\
1 & $1,24 \mathrm{~b}$ & $0,55 \mathrm{~b}$ & $0,62 \mathrm{a}$ & $0,68 \mathrm{a}$ & 43,16 a \\
2 & $1,17 \mathrm{~b}$ & $0,49 \mathrm{bc}$ & $0,61 \mathrm{a}$ & $0,74 \mathrm{a}$ & 47,83 & $\mathrm{a}$ \\
3 & $1,22 \mathrm{~b}$ & $0,47 \mathrm{c}$ & $0,72 \mathrm{a}$ & $0,78 \mathrm{a}$ & $44,95 \mathrm{a}$ \\
\hline
\end{tabular}


À medida que os sintomas evoluíram, as concentrações de fósforo nas folhas diminuíram, mostrando assim uma diferenciação do nutriente na comparação de plantas assintomáticas e sintomáticas. $O$ fósforo passou de $1,51 \mathrm{~g} \mathrm{~kg}^{-1}$, nas plantas assintomáticas, para $1,24 \mathrm{~g} \mathrm{~kg}^{-1}$ nas plantas no primeiro estágio de sintomatologia da doença. Observou-se também queda na concentração de fósforo das folhas de citrus cv. Valência com a evolução do declínio em experimentos realizados no Brasil (Tavares, 1987 e Coelho et al., 1983).

Segundo Violante Netto et al. (1988) e Rodrigues et al. (1991), a concentração de fósforo adequada nas folhas de citros geradas na primavera, com seis meses de idade, de ramos com fruto é de 1,20-1,60 $\mathrm{g} \mathrm{kg}^{-1}$, e comparada com a média das coletas realizadas de $1,28 \mathrm{~g} \mathrm{~kg}^{-1}$, considera-se adequada. As plantas assintomáticas apresentaram $1,51 \mathrm{~g} \mathrm{~kg}^{-1}$, mostrando também concentração ótima. Considerando-se a concentração adequada para a época de coleta do experimento de $1,20-1,50 \mathrm{~g} \mathrm{~kg}^{-1}$ (Malavolta \& Prates, 1994), as concentrações ainda continuaram adequadas.

Nos galhos, essa diminuição foi ainda mais acentuada, causando quedas do nutriente até o ultimo estágio de sintomatologia, que corresponde à planta morta. Nas plantas assintomáticas obtive-se $0,68 \mathrm{~g} \mathrm{~kg}^{-1}$ de fósforo, enquanto as plantas no estágio inicial de sintomatologia apresentaram $0,55 \mathrm{~g} \mathrm{~kg}^{-1}$, e as plantas no último estágio da doença $0,47 \mathrm{~g} \mathrm{~kg}^{-1}$ de fósforo. Segundo Chapman (1968), a concentração adequada de fósforo nos galhos é de $2,20 \mathrm{~g} \mathrm{~kg}^{-1}$, sendo assim o nutriente já estava deficiente e com a evolução da doença a deficiência se acentuou.

Essas alterações que ocorreram com o fósforo nas folhas e nos galhos com a evolução da sintomatologia não têm relação com seu teor no solo, devido a não alteração do nutriente, sendo que o teor do nutriente que foi encontrado no solo é considerado adequado (Raij et al., 1996).

Quanto às concentrações de fósforo nas raizes e na casca do tronco, estas foram consideradas deficientes (Chapman, 1968), sendo que os valores adequados seriam respectivamente de $2,50 \mathrm{~g} \mathrm{~kg}^{-1}$ e de $2,40 \mathrm{~g} \mathrm{~kg}^{-1}$.

Nas épocas de coleta, pode-se verificar que em toda a planta, folhas, galhos, casca do tronco e raizes, tiveram alterações nutricionais com o passar do tempo (Tabela 7). 
Tabela 7. Concentrações de fósforo em plantas de citros, variedade Pêra Rio, e no solo nas épocas de coleta

\begin{tabular}{|c|c|c|c|c|c|c|}
\hline Coletas & Folhas & Galhos & & $\begin{array}{l}\text { Casca do tronco } \\
-\mathrm{g} \mathrm{kg}^{-1}\end{array}$ & Raizes & $\begin{array}{c}\text { Solo } \\
\mathrm{mg} \mathrm{dm}^{-3}\end{array}$ \\
\hline 24 junho & $1,28 \mathrm{~b}$ & 0,54 & $\mathrm{~b}$ & $0,62 \mathrm{~b}$ & $0,94 \mathrm{~b}$ & $39,19 b$ \\
\hline 29 agosto & $1,01 \mathrm{c}$ & 0,40 & $c$ & $0,43 \mathrm{c}$ & $0,64 \mathrm{c}$ & 65,47 a \\
\hline 3 outubro & $0,97 \mathrm{c}$ & 0,35 & $c$ & $0,45 \mathrm{c}$ & $0,56 \mathrm{c}$ & $41,50 b$ \\
\hline 8 novembro & $1,35 \mathrm{~b}$ & 0,40 & $c$ & $0,48 \mathrm{c}$ & $0,48 \mathrm{c}$ & $46,00 \quad b$ \\
\hline 13 dezembro & $1,83 \mathrm{a}$ & 1,04 & $a$ & $1,22 a$ & $1,17 \mathrm{a}$ & $45,15 b$ \\
\hline
\end{tabular}

As concentrações de fósforo na ultima coleta foram alterados com relação às demais coletas, ocorrendo um aumento. O teor do nutriente não foi alterado no solo, como ocorreu na planta. No entanto, também não houve aplicação do nutriente foliar, como era de se esperar com essa alteração. O aumento que ocorreu na raiz pode terse refletido na planta toda, podendo ser devido ao aumento da disponibilidade do nutriente próximo ao sistema radicular, com o aumento da umidade, facilitando assim a absorção por difusão (Malavolta, 1980 e Havlin et al., 1999).

As concentrações de fósforo na planta acompanharam muito pouco os teores do fósforo no solo. O fósforo sofreu as seguintes alterações com o passar do tempo: nas folhas na primeira coleta a concentração era de $1,28 \mathrm{~g} \mathrm{~kg}^{-1}$, passando para $1,01 \mathrm{~g}$ $\mathrm{kg}^{-1}$ na segunda coleta e voltando a aumentar para $1,83 \mathrm{~g} \mathrm{~kg}^{-1}$ na última coleta, nos galhos o valor inicial era de $0,54 \mathrm{~g} \mathrm{~kg}^{-1}$, passando para $0,40 \mathrm{~g} \mathrm{~kg}^{-1}$ na segunda coleta $\mathrm{e}$ voltando a aumentar na última coleta para $1,04 \mathrm{~g} \mathrm{~kg}^{-1}$, na casca do tronco a primeira coleta apresentou concentração de $0,62 \mathrm{~g} \mathrm{~kg}^{-1}$, passando posteriormente para $0,43 \mathrm{~g}$ $\mathrm{kg}^{-1} \mathrm{e}$ voltando a aumentar para $1,22 \mathrm{~g} \mathrm{~kg}^{-1}$ na última coleta, nas raízes a tendência foi a mesma, passando de $0,94 \mathrm{~g} \mathrm{~kg}^{-1}$, para $0,64 \mathrm{~g} \mathrm{~kg}^{-1}$ e aumentando para $1,17 \mathrm{~g} \mathrm{~kg}^{-1} \mathrm{na}$ última coleta.

Quanto à interação entre época de amostragem e estágios de sintomatologia da doença, elas foram observadas nas folhas e nos galhos (Tabelas 8 e 9). 
Tabela 8. Concentrações de fósforo na interação entre épocas de coleta e estágios de manifestação de sintomas na planta, nas folhas de plantas da variedade Pêra Rio

\begin{tabular}{cccccc}
\hline & 0 & 1 & 2 & 3 \\
\hline 24 junho & $1,52 \mathrm{BCa}$ & $1,23 \mathrm{Ba}$ & $1,24 \mathrm{ABa}$ & $1,15 \mathrm{Ba}$ \\
29 agosto & $1,12 \mathrm{Ca}$ & $0,99 \mathrm{Ba}$ & $0,96 \mathrm{Ba}$ & $0,95 \mathrm{Ba}$ \\
3 outubro & $1,18 \mathrm{Ca}$ & $0,85 \mathrm{Ba}$ & $0,87 \mathrm{Ba}$ & $0,99 \mathrm{Ba}$ \\
8 novembro & $1,76 \mathrm{ABa}$ & $1,33 \mathrm{Bb}$ & $1,15 \mathrm{Bb}$ & $1,15 \mathrm{Bb}$ \\
13 dezembro & $1,99 \mathrm{Aa}$ & $1,8 \mathrm{Aa}$ & $1,63 \mathrm{Aa}$ & $1,88 \mathrm{Aa}$ \\
\hline
\end{tabular}

Médias seguidas pela mesma letra, minúscula na linha e maiúscula na coluna, não diferem entre si pelo teste de Tukey a $5 \%$.

Quanto às folhas percebe-se que na última coleta, em todos os estágios de sintomatologia, os resultados foram maiores quando comparados com as demais coletas.

Além disso, apenas na coleta de novembro é que houve uma diferenciação entre as plantas assintomáticas com $1,76 \mathrm{~g} \mathrm{~kg}^{-1}$, e as plantas nos diversos estágios de sintomatologia, como $1,15 \mathrm{~g} \mathrm{~kg}^{-1}$ nas plantas que apresentavam grau intermediário de manifestação de sintomas.

Tabela 9. Concentrações de fósforo na interação entre épocas de coleta e estágios de manifestação de sintomas na planta, nos galhos de plantas da variedade Pêra Rio

\begin{tabular}{crrrrr}
\hline & 0 & 1 & 2 & 3 \\
\hline 24 junho & $0,74 \mathrm{Ba}$ & $0,6 \mathrm{Bab}$ & $0,44 \mathrm{Bbc}$ & $0,38 \mathrm{Bc}$ \\
29 agosto & $0,65 \mathrm{BCa}$ & $0,35 \mathrm{Cb}$ & $0,31 \mathrm{Bb}$ & $0,31 \mathrm{Bb}$ \\
3 outubro & $0,4 \mathrm{Da}$ & $0,34 \mathrm{Ca}$ & $0,33 \mathrm{Ba}$ & $0,34 \mathrm{Ba}$ \\
8 novembro & $0,51 \mathrm{CDa}$ & $0,41 \mathrm{CBa}$ & $0,36 \mathrm{Ba}$ & $0,33 \mathrm{Ba}$ \\
13 dezembro & $1,11 \mathrm{Aa}$ & $1,04 \mathrm{Aa}$ & $1,04 \mathrm{Aa}$ & $0,98 \mathrm{Aa}$ \\
\hline
\end{tabular}

Médias seguidas pela mesma letra, minúscula na linha e maiúscula na coluna, não diferem entre si pelo teste de Tukey a $5 \%$.

Nos galhos ocorreu a mesma tendência das folhas, sendo que na última coleta, em todos os estágios de sintomatologia, os resultados foram maiores quando comparado com as demais coletas. Ocorreu também diferença entre os estágios de sintomatologia nas coletas do dia 24 de junho e 29 de agosto, onde as plantas assintomáticas possuíram as maiores concentrações de fósforo. 


\subsubsection{Potássio}

Ao se analisar a concentração de potássio dentro dos estágios de sintomatologia da morte súbita do citros, pode-se notar diferenças do nutriente nas folhas e galhos (Tabela 10).

Tabela 10. Concentrações de potássio em plantas de citros, variedade Pêra Rio, e do solo nos estágios da morte súbita do citros

\begin{tabular}{ccccccr}
\hline Sintomas & Folha & Galho & \multicolumn{2}{c}{ Casca do tronco } & Raiz & $\begin{array}{c}\text { Solo } \\
\text { mmol }_{c} \text { dm- }^{3}\end{array}$ \\
\hline 0 & 12,81 a & 4,49 a & 5,46 a & 6,72 a & 1,92 a \\
1 & 11,23 bc & 4,00 ab & 4,79 a & 5,90 a & 1,88 a \\
2 & 11,56 ab & 3,75 ab & 4,00 a & 5,85 a & 2,22 a \\
3 & $9,79 \mathrm{c}$ & $3,14 \mathrm{~b}$ & 4,81 a & 5,48 a & 1,89 a \\
\hline
\end{tabular}

À medida que os sintomas evoluíram, as concentrações de potássio nas folhas diminuíram, caindo de $12,81 \mathrm{~g} \mathrm{~kg}^{-1}$ nas plantas assintomáticas para $11,23 \mathrm{~g} \mathrm{~kg}^{-1}$ nas plantas no primeiro estágio de sintomatologia da doença, chegando a $9,79 \mathrm{~g} \mathrm{~kg}^{-1}$ nas folhas das plantas no último estágio da doença. Como na morte súbita, ocorreu também queda da concentração de potássio nas folhas de plantas afetadas por declínio (Wutscher \& Hardesty, 1979 e Coelho et al., 1983) e por clorose variegada do citros (Ricci et al., 2001).

Segundo Violante Netto et al. (1988) e Rodrigues et al. (1991), a concentração de potássio adequado nas folhas de citros, geradas na primavera, com seis meses de idade, de ramos com fruto é de $12,00-17,00 \mathrm{~g} \mathrm{~kg}^{-1}$, que quando comparada com a média das coletas realizadas de $11,35 \mathrm{~g} \mathrm{~kg}^{-1} \mathrm{e}$ das plantas assintomáticas que apresentaram 12,81 $\mathrm{g} \mathrm{kg}^{-1}$, resulta em uma concentração abaixo da adequada na média geral e adequada nas plantas assintomáticas. Considerando-se referir a concentração adequada para a época da coleta no experimento de $10,00-12,00 \mathrm{~g} \mathrm{~kg}^{-1}$ (Malavolta \& Prates, 1994), os valores encontrados também foram considerados adequados.

Nos galhos essa diminuição não foi tão acentuada, passando de $4,49 \mathrm{~g} \mathrm{~kg}^{-1}$ nas plantas assintomáticas para $3,14 \mathrm{~g} \mathrm{~kg}^{-1}$ nas plantas que apresentavam o último grau de sintomatologia. Segundo Chapman (1968), a concentração adequada do nutriente é de 
2,40 $\mathrm{g} \mathrm{kg}^{-1}$, sendo assim, mesmo com a queda do nutriente devido ao avanço da doença, ele não entrou em uma faixa de deficiência.

Essas alterações que ocorreram com o potássio nas folhas e nos galhos com a evolução da sintomatologia não tiveram relação com seu teor no solo, devido à não alteração do nutriente no solo com a evolução dos sintomas. Segundo Raij et al. (1996), o teor do nutriente encontrado no solo estava na faixa adequada. Quanto à concentração de potássio na casca do tronco e nas raizes também se encontravam adequadas (Chapman, 1968).

Quanto às épocas de coleta, percebe-se novamente que as concentrações de potássio foram afetadas apenas nas folhas e galhos, da mesma forma que ocorreu com os estágios de sintomatologia (Tabela 11).

Tabela 11. Concentrações de potássio em plantas de citros, variedade Pêra Rio, e do solo nas épocas de coleta

\begin{tabular}{ccccccc}
\hline Coletas & Folhas & Galhos & $\begin{array}{c}\text { Casca do tronco } \\
\text { kg-1 }^{-1}\end{array}$ & Raízes & $\begin{array}{c}\text { Solo } \\
\mathrm{mmol}_{\mathrm{c}} \mathrm{dm}^{-3}\end{array}$ \\
\hline 24 junho & $10,74 \mathrm{bc}$ & $3,82 \mathrm{~b}$ & $4,82 \mathrm{a}$ & $6,19 \mathrm{a}$ & $2,59 \mathrm{a}$ \\
29 agosto & $11,00 \mathrm{~b}$ & $3,44 \mathrm{~b}$ & $4,51 \mathrm{a}$ & $6,07 \mathrm{a}$ & $2,37 \mathrm{ab}$ \\
3 outubro & $10,80 \mathrm{bc}$ & $3,62 \mathrm{~b}$ & $5,66 \mathrm{a}$ & $6,79 \mathrm{a}$ & $1,35 \mathrm{bc}$ \\
8 novembro & $15,14 \mathrm{a}$ & $5,02 \mathrm{a}$ & $4,49 \mathrm{a}$ & $5,79 \mathrm{a}$ & $1,80 \mathrm{c}$ \\
13 dezembro & $9,07 \mathrm{c}$ & $3,33 \mathrm{~b}$ & $4,35 \mathrm{a}$ & $5,11 \mathrm{a}$ & $1,49 \mathrm{c}$ \\
\hline
\end{tabular}

Ocorreu um aumento na concentração de potássio da parte aérea, em galhos e folhas, na quarta coleta e, queda posterior, no entanto, isso não foi reflexo do seu teor no solo, que teve uma queda constante com o passar do tempo. Pode ter ocorrido um deslocamento do nutriente de uma parte da planta para outra, devido ao nutriente ser móvel no floema (Marschner, 1997). Outro fato é que, com o florescimento e início da frutificação, o nutriente que mais se desloca das folhas para as brotações novas é o potássio, ocorrendo assim, na última coleta, uma queda do nutriente (Castro et al., 2001).

Quanto à interação entre época de amostragem e estágios de sintomatologia da doença, ela ocorreu apenas nas folhas (Tabela 12). 
Tabela 12. Concentrações de potássio na interação entre épocas de coleta e estágios de manifestação de sintomas na planta, nas folhas de plantas da variedade Pêra Rio

\begin{tabular}{crrrrr}
\hline & \multicolumn{2}{c}{0} & 1 & 2 & \multicolumn{1}{c}{3} \\
\hline 24 junho & $11,86 \mathrm{ABa}$ & $9,89 \mathrm{Ba}$ & $12,24 \mathrm{ABa}$ & $8,99 \mathrm{ABa}$ \\
29 agosto & $13,32 \mathrm{ABa}$ & $11,67 \mathrm{Ba}$ & $10,77 \mathrm{ABa}$ & $8,25 \mathrm{ABa}$ \\
3 outubro & $12,18 \mathrm{ABa}$ & $8,93 \mathrm{Ba}$ & $10,01 \mathrm{Ba}$ & $12,07 \mathrm{Aa}$ \\
8 novembro & $15,81 \mathrm{Aa}$ & $16,83 \mathrm{Aa}$ & $14,73 \mathrm{Aa}$ & $13,18 \mathrm{Aa}$ \\
13 dezembro & $10,9 \mathrm{Ba}$ & $8,86 \mathrm{Ba}$ & $10,07 \mathrm{Ba}$ & $6,46 \mathrm{Ba}$ \\
\hline
\end{tabular}

Médias seguidas pela mesma letra, minúscula na linha e maiúscula na coluna, não diferem entre si pelo teste de Tukey a $5 \%$.

Não houve diferença significativa do nutriente nos estágios da doença em nenhuma época de coleta, no entanto, nota-se um aumento do nutriente na quarta coleta e queda posterior, como citado já anteriormente, quando se comparou às épocas de coleta.

\subsubsection{Cálcio}

Ao se analisar a concentração de cálcio dentro dos estágios de sintomatologia da morte súbita, pode-se notar diferenças do nutriente apenas nas raízes. O que condiz com sua principal função na planta, desenvolvimento do sistema radicular (Marschner, 1997) (Tabela 13).

Tabela 13. Concentrações de cálcio em plantas de citros, variedade Pêra Rio, e do solo nos estágios da morte súbita do citros

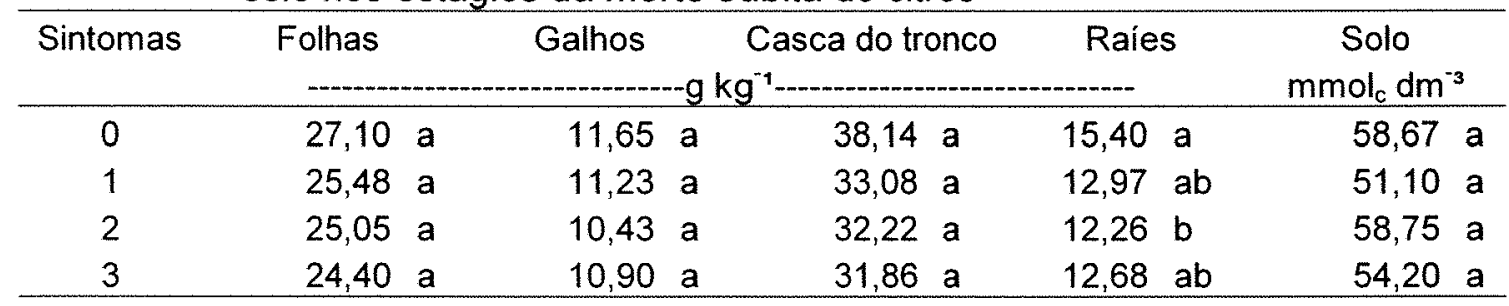

À medida que os sintomas evoluíram, as concentrações de cálcio nas raizes diminuíram, mostrando assim, uma diferenciação do nutriente na comparação entre plantas assintomáticas e sintomáticas. O nutriente reduziu de $15,40 \mathrm{~g} \mathrm{~kg}^{-1}$, nas raizes de plantas assintomáticas, para $12,97 \mathrm{~g} \mathrm{~kg}^{-1}$ nas plantas no primeiro estágio de sintomatologia da doença. Segundo Chapman (1968), a concentração ideal de cálcio 
nas raízes finas é de $44,6 \mathrm{~g} \mathrm{~kg}^{-1}$. Sendo assim, a planta assintomática já possuía concentração inadequada do nutriente, e com o avanço da doença, caiu ainda mais.

Como já citado anteriormente, esse nutriente juntamente com o boro, são os dois principais formadores de sistema radicular (Marschner, 1997). Sendo assim, a sua queda pode provocar uma diminuição de volume de raizes, principalmente radicelas, que são as principais responsáveis pela absorção de nutrientes pela planta. Essas alterações que ocorreram com o cálcio nas raizes, com a evolução da sintomatologia, não têm relação com seu teor no solo.

No caso da morte súbita, não ocorreu alteração na concentração de cálcio das folhas de plantas afetadas, no entanto, com o avanço do declínio, ocorreu aumento do nutriente (Coelho et al., 1983) e, quando se analisou as plantas com clorose variegada do citros ocorreu o contrário, sendo que a concentração do nutriente caiu com o avanço da doença (Ricci et al., 2001).

Nas folhas, a concentração do cálcio não foi alterada, sendo que, segundo Violante Netto et al. (1988) e Rodrigues et al. (1991), a concentração de cálcio adequada nas folhas de citros, geradas na primavera, com seis meses de idade, de ramos com fruto é de $30,00-45,00 \mathrm{~g} \mathrm{~kg}^{-1}$, que quando comparada com a média das coletas realizadas de $25,51 \mathrm{~g} \mathrm{~kg}^{-1} \mathrm{e}$ das plantas assintomáticas que apresentaram $27,10 \mathrm{~g} \mathrm{~kg}^{-1}$ de cálcio, resulta nos dois casos uma concentração um pouco abaixo da ideal. Considerando-se a concentração adequada para a época coletada de 30,00$45,00 \mathrm{~g} \mathrm{~kg}^{-1}$ os valores não estavam adequados.

Quanto ao cálcio nos galhos e casca do tronco, este se encontrou adequado para os galhos e deficiente para a casca do tronco que deveria ser de no mínimo 44,00 $\mathrm{g} \mathrm{kg}^{-1}$ (Chapman, 1968).

Quanto às épocas de coletas, pode ser notado que as concentrações de cálcio foram afetadas nas folhas e casca do tronco, mostrando assim uma queda do nutriente com o passar das coletas (Tabela 14). 
Tabela 14. Concentrações de cálcio em plantas de citros, variedade Pêra Rio, e do solo nas épocas de coleta

\begin{tabular}{|c|c|c|c|c|c|c|}
\hline Coletas & Folhas & Galhos & & $\begin{array}{l}\text { Casca do tronco } \\
\mathrm{kg}^{-1}\end{array}$ & Raizes & $\begin{array}{l}\text { Solo } \\
\mathrm{mmol}^{-\mathrm{dm}^{-3}}\end{array}$ \\
\hline 24 junho & 31,36 a & 10,34 & $a$ & 42,12 a & 12,62 a & $42,44 b$ \\
\hline 29 agosto & 29,85 a & 10,69 & a & $40,48 a b$ & $12,71 \quad a$ & 83,54 a \\
\hline 3 outubro & $17,56 \mathrm{c}$ & 10,88 & a & $19,08 \mathrm{c}$ & $12,26 a$ & $42,15 \mathrm{~b}$ \\
\hline 8 novembro & $23,80 \mathrm{~b}$ & 11,41 & a & $33,45 \quad \mathrm{~b}$ & $14,09 a$ & $54,48 \quad b$ \\
\hline 13 dezembro & $24,95 b$ & 11,94 & a & $33,98 \mathrm{~b}$ & 14,94 a & $53,13 \quad b$ \\
\hline
\end{tabular}

As concentrações de cálcio nas folhas das duas primeiras coletas ficaram estáveis, no entanto, ocorreu uma queda após essa época, sendo que a partir da terceira coleta, o cálcio passou a ser considerado deficiente nas folhas (Malavolta \& Prates, 1994). Essa tendência nutricional ocorreu também, na casca do tronco, com redução na concentração do nutriente a partir da terceira coleta.

O teor de cálcio também teve uma queda no solo a partir da terceira coleta, podendo ter afetado no nutriente dessas partes da planta. Como este nutriente é imóvel na planta, a única fonte do mesmo para as folhas é a partir da absorção radicular, sendo transportado juntamente com a seiva inorgânica pelo xilema. Além disso não pode ter ocorrido redistribuição para as flores, pois a forma que o cálcio se encontra nas folhas é na sua maioria insolúvel (pectato de cálcio) (Marschner, 1997 e Malavolta \& Violante Netto, 1989). Sendo assim, ocorrendo queda do referido nutriente no xilema, essa queda deverá refletir-se também nas folhas recém maduras, que foram utilizadas nas coletas.

Quanto à interação entre época de amostragem e estágios de sintomatologia da doença, esta foi observada apenas nas folhas (Tabela 15).

Tabela 15. Concentrações de cálcio na interação entre épocas de coleta e estágios de manifestação de sintomas na planta, nas folhas de plantas da variedade Pêra Rio

\begin{tabular}{ccrcrr}
\hline & 0 & 1 & 2 & 3 \\
\hline 24 junho & \multicolumn{1}{c}{$33,91 \mathrm{Aa}$} & $32,3 \mathrm{Aa}$ & $28,34 \mathrm{Aa}$ & $30,9 \mathrm{Aa}$ \\
29 agosto & $29,06 \mathrm{Aa}$ & $30,23 \mathrm{Aa}$ & $30,36 \mathrm{Aa}$ & $39,83 \mathrm{ABa}$ \\
3 outubro & $17,34 \mathrm{Ba}$ & $17,26 \mathrm{Ca}$ & $18,55 \mathrm{Ba}$ & $17,1 \mathrm{Ca}$ \\
8 novembro & $24,96 \mathrm{ABa}$ & $20,6 \mathrm{BCa}$ & $25,33 \mathrm{ABa}$ & $24,32 \mathrm{ABCa}$ \\
13 dezembro & $30,21 \mathrm{Aa}$ & $26,99 \mathrm{ABab}$ & $22,75 \mathrm{ABab}$ & $19,83 \mathrm{BCb}$ \\
\hline
\end{tabular}

Médias seguidas pela mesma letra, minúscula na linha e maiúscula na coluna, não diferem entre si pelo teste de Tukey a $5 \%$. 
Apenas na última coleta, ocorreu diferença entre as plantas assintomáticas e as demais plantas, sendo que a concentração de cálcio caiu de $30,21 \mathrm{~g} \mathrm{~kg}^{-1}$ nas plantas assintomáticas para $26,99 \mathrm{~g} \mathrm{~kg}^{-1}$ nas plantas no primeiro estágio de sintomatologia, chegando a $19,83 \mathrm{~g} \mathrm{~kg}^{-1}$ nas plantas em estágio terminal da doença.

\subsubsection{Magnésio}

Ao se analisar a concentração de magnésio dentro dos estágios de sintomatologia da morte súbita do citros, pode-se observar que não ocorreu diferença em nenhuma parte da planta (Tabela 16).

Tabela 16. Concentrações de magnésio em plantas de citros, variedade Pêra Rio, e do solo nos estágios da morte súbita do citros

\begin{tabular}{ccccccr}
\hline Sintomas & Folhas & Galhos & $\begin{array}{c}\text { Casca do tronco } \\
\text { Raizes }\end{array}$ & $\begin{array}{r}\text { Solo } \\
\mathrm{mmol}_{\mathrm{c}} \mathrm{dm}^{-3}\end{array}$ \\
\hline 0 & $2,44 \mathrm{a}$ & $0,58 \mathrm{a}$ & $1,29 \mathrm{a}$ & $0,66 \mathrm{a}$ & $11,29 \mathrm{a}$ \\
1 & 2,31 a & $0,67 \mathrm{a}$ & $1,22 \mathrm{a}$ & $0,53 \mathrm{a}$ & $8,80 \mathrm{a}$ \\
2 & $2,31 \mathrm{a}$ & $0,59 \mathrm{a}$ & $1,22 \mathrm{a}$ & $0,62 \mathrm{a}$ & $11,30 \mathrm{a}$ \\
3 & $2,19 \mathrm{a}$ & $0,58 \mathrm{a}$ & $1,30 \mathrm{a}$ & $0,60 \mathrm{a}$ & $9,88 \mathrm{a}$ \\
\hline
\end{tabular}

O magnésio não afetou a velocidade de desenvolvimento de sintomatologia da morte súbita do citros na variedade Pêra Rio sobre limão 'Cravo', pois sua quantidade em toda a planta (folhas, galhos, casca do tronco e raízes) não foi alterada com o desenvolvimento da doença. $O$ solo também não teve alteração nutricional com o avanço da sintomatologia da doença, sendo considerado um teor adequado (Raij et al., 1996).

No caso da morte súbita não ocorreu alteração da concentração de magnésio nas folhas de plantas afetadas, no entanto com o avanço do declínio ocorreu queda desse nutriente nas folhas (Giroto, 1990) e, quando se analisou plantas com clorose variegada do citros, também ocorreu uma queda desse nutriente na folha, com o avanço da doença (Ricci et al., 2001).

Segundo Violante Netto et al. (1988) e Rodrigues et al. (1991), a concentração de magnésio adequada nas folhas de citros geradas na primavera, com seis meses de idade, de ramos com fruto é de $3,00-4,90 \mathrm{~g} \mathrm{~kg}^{-1}$, que quando comparada com a média 
das coletas realizadas de $2,31 \mathrm{~g} \mathrm{~kg}^{-1}$, e das plantas assintomáticas que apresentaram $2,44 \mathrm{~g} \mathrm{~kg}^{-1}$, resulta nos dois casos em uma concentração um pouco abaixo do ideal.

Além das folhas, o magnésio da casca do tronco e das raizes também estava deficientes. Segundo Chapman (1968), a concentração ideal do nutriente nas raízes é de $2,2 \mathrm{~g} \mathrm{~kg}^{-1}$, na casca do tronco é de $3,5 \mathrm{~g} \mathrm{~kg}^{-1}$ e nos galhos é de $0,8 \mathrm{~g} \mathrm{~kg}^{-1}$.

Quanto às épocas de coletas pode-se notar, que as concentrações de magnésio foram afetados nas folhas, galhos e raízes, mostrando uma queda do nutriente com o passar das coletas (Tabela 17).

Tabela 17. Concentrações de magnésio em plantas de citros, variedade Pêra Rio, e do solo nas épocas de coleta

\begin{tabular}{ccccccr}
\hline Coletas & Folhas & Galhos & Caule & Raízes & $\begin{array}{r}\text { Solo } \\
\mathrm{mmol}_{\mathrm{c}} \mathrm{dm}^{-3}\end{array}$ \\
\hline 24 junho & $2,79 \mathrm{a}$ & $0,75 \mathrm{a}$ & $1,34 \mathrm{a}$ & $0,80 \mathrm{a}$ & $8,38 \mathrm{~b}$ \\
29 agosto & $2,15 \mathrm{~b}$ & $0,70 \mathrm{ab}$ & $1,23 \mathrm{a}$ & $0,70 \mathrm{ab}$ & $16,52 \mathrm{a}$ \\
3 outubro & $2,39 \mathrm{ab}$ & $0,50 \mathrm{c}$ & $1,28 \mathrm{a}$ & $0,48 \mathrm{c}$ & $7,27 \mathrm{~b}$ \\
8 novembro & $2,16 \mathrm{~b}$ & $0,54 \mathrm{bc}$ & $1,17 \mathrm{a}$ & $0,49 \mathrm{c}$ & $10,56 \mathrm{~b}$ \\
13 dezembro & $2,06 \mathrm{~b}$ & $0,52 \mathrm{c}$ & $1,26 \mathrm{a}$ & $0,53 \mathrm{bc}$ & $8,63 \mathrm{~b}$ \\
\hline
\end{tabular}

O magnésio nas folhas sofreu queda quando se comparou a primeira época com as demais, passando de $2,79 \mathrm{~g} \mathrm{~kg}^{-1}$ na primeira coleta para $2,15 \mathrm{~g} \mathrm{~kg}^{-1}$ na segunda coleta. Essa tendência nutricional ocorreu também nos galhos e raízes, no entanto nessas duas partes da planta, a queda foi mais acentuada. Isso pode ter ocorrido pelo fato de o magnésio ser um elemento móvel na planta e tender a se deslocar para as partes mais novas da planta, tais como as brotações e folhas novas, sendo o magnésio, o componente central da molécula de clorofila (Marschner, 1997). Essa queda na concentração do nutriente a partir da terceira coleta também ocorreu no solo, podendo assim ter ocorrido reflexo do mesmo para a planta.

O teor de magnésio no solo na primeira coleta, no entanto, não acompanhou a tendência da planta, mesmo estando seu teor menor do que na segunda coleta, as concentrações nas folhas, casca do tronco e raizes estavam maiores.

\subsubsection{Enxofre}

Ao se analisar a concentração de enxofre dentro dos estágios de sintomatologia da morte súbita do citros, pode-se observar diferenças nas folhas e raizes (Tabela 18). 
Tabela 18. Concentrações de enxofre em plantas de citros, variedade Pêra Rio, e do solo nos estágios da morte súbita do citros

\begin{tabular}{cccccccr}
\hline Sintomas & Folhas & Galhos & $\begin{array}{c}\text { Casca do tronco } \\
\text { Raizes }\end{array}$ & $\begin{array}{r}\text { Solo } \\
\mathrm{mg} \mathrm{dm}^{-3}\end{array}$ \\
\hline 0 & $2,96 \mathrm{a}$ & $0,74 \mathrm{a}$ & $1,03 \mathrm{a}$ & $1,37 \mathrm{a}$ & $19,26 \mathrm{a}$ \\
1 & $2,49 \mathrm{~b}$ & $0,75 \mathrm{a}$ & $0,96 \mathrm{a}$ & $0,93 \mathrm{~b}$ & $17,85 \mathrm{a}$ \\
2 & $2,36 \mathrm{~b}$ & $0,68 \mathrm{a}$ & $0,91 \mathrm{a}$ & $0,95 \mathrm{~b}$ & $16,48 \mathrm{a}$ \\
3 & $2,13 \mathrm{c}$ & $0,77 \mathrm{a}$ & $1,01 \mathrm{a}$ & $0,90 \mathrm{~b}$ & $16,88 \mathrm{a}$ \\
\hline
\end{tabular}

À medida que os sintomas evoluíram, o enxofre nas folhas diminuiu, mostrando uma queda constante com a evolução dos sintomas, desde as plantas assintomáticas até o ultimo grau de sintomatologia da morte súbita do citros. O nutriente caiu de $2,96 \mathrm{~g}$ $\mathrm{kg}^{-1}$ nas plantas assintomáticas para $2,49 \mathrm{~g} \mathrm{~kg}^{-1}$ nas plantas no primeiro estágio de sintomatologia da doença, chegando a $2,13 \mathrm{~g} \mathrm{~kg}^{-1}$ nas folhas das plantas no último estágio da doença. No entanto, em um experimento realizado com o declínio do citros ocorreu o contrário, sendo que o referido nutriente aumentava com o decorrer da doença (Wutscher \& McDonald, 1986).

Segundo Violante Netto et al. (1988) e Rodrigues et al. (1991), a concentração de enxofre considerada adequada nas folhas de citros geradas na primavera, com seis meses de idade, de ramos com fruto é de $2,00-3,90 \mathrm{~g} \mathrm{~kg}^{-1}$, que quando comparada com a média das coletas realizadas de $2,48 \mathrm{~g} \mathrm{~kg}^{-1} \mathrm{e}$ das plantas assintomáticas que apresentaram $2,96 \mathrm{~g} \mathrm{~kg}^{-1}$ de magnésio, resulta nos dois casos em valores considerados adequados.

Nas raízes, essa diminuição não foi tão acentuada, passando de $1,37 \mathrm{~g} \mathrm{~kg}^{-1}$ nas plantas assintomáticas para $0,93 \mathrm{~g} \mathrm{~kg}^{-1}$ nas plantas que se apresentavam no primeiro grau de sintomatologia da doença e $0,90 \mathrm{~g} \mathrm{~kg}^{-1}$ nas plantas em estágio final de sintomatologia. Segundo Chapman (1968), a concentração considerada adequada de enxofre nas raízes finas é de $1,40 \mathrm{~g} \mathrm{~kg}^{-1}$, sendo que as plantas assintomáticas apresentavam-se adequadas, no entanto, com o decorrer do avanço da doença, a concentração diminuiu, ficando assim deficiente.

As alterações que ocorreram com o enxofre nas folhas e raizes, com a evolução da sintomatologia, não tiveram relação com seu teor no solo, devido à não alteração do mesmo no solo com a evolução dos sintomas, sendo que o teor do nutriente no solo se encontrou adequado (Raij et al., 1996). 
Quanto ao enxofre nos galhos e casca do tronco, estes se encontravam deficientes (Chapman, 1968), pois deveriam estar acima de $1,20 \mathrm{~g} \mathrm{~kg}^{-1}$ e $1,80 \mathrm{~g} \mathrm{~kg}^{-1}$ respectivamente.

Nas épocas de coletas, notou-se que as concentrações de enxofre foram afetadas em todas as partes da planta (folhas, galhos, casca do tronco e raízes) (Tabela 19).

Tabela 19. Concentrações de enxofre em plantas de citros, variedade Pêra Rio, e do solo nas épocas de coleta

\begin{tabular}{clllllll}
\hline Coletas & Folhas & Galhos & $\begin{array}{c}\text { Casca do tronco } \\
\text { Raizes }\end{array}$ & $\begin{array}{r}\text { Solo } \\
\mathrm{mg} \mathrm{dm}^{-3}\end{array}$ \\
\hline 24 junho & $2,49 \mathrm{bc}$ & $0,60 \mathrm{c}$ & $0,89 \mathrm{~b}$ & $1,03 \mathrm{bc}$ & $11,61 \mathrm{a}$ \\
29 agosto & $2,57 \mathrm{ab}$ & $0,51 \mathrm{c}$ & $0,71 \mathrm{~d}$ & $0,83 \mathrm{bc}$ & $18,52 \mathrm{a}$ \\
3 outubro & $2,25 \mathrm{c}$ & $0,77 \mathrm{~b}$ & $0,97 \mathrm{~b}$ & $1,08 \mathrm{~b}$ & $20,34 \mathrm{a}$ \\
8 novembro & $2,33 \mathrm{bc}$ & $0,61 \mathrm{c}$ & $0,80 \mathrm{c}$ & $0,77 \mathrm{c}$ & $20,78 \mathrm{a}$ \\
13 dezembro & $2,79 \mathrm{a}$ & $1,19 \mathrm{a}$ & $1,50 \mathrm{a}$ & $1,48 \mathrm{a}$ & $14,89 \mathrm{a}$ \\
\hline
\end{tabular}

Ocorreu um aumento na concentração de enxofre na última coleta em todas as partes da planta, no entanto, não se pode fazer qualquer correlação com o solo, pois este não apresentou esta tendência. Essas alterações do nutriente podem ter ocorrido dentro da planta, tendo assim uma maior concentração do nutriente, devido à diminuição da massa seca da mesma.

Quanto à interação entre época de amostragem e estágios de sintomatologia da doença, esta ocorreu nas folhas e na casca do tronco (Tabelas 20 e 21).

Tabela 20. Concentrações de enxofre na interação entre épocas de coleta e estágios de manifestação de sintomas na planta, nas folhas de plantas da variedade Pêra Rio

\begin{tabular}{crrlrrr}
\hline & 0 & & 1 & 2 & 3 \\
\hline 24 junho & $2,91 \mathrm{Aa}$ & $2,58 \mathrm{ABab}$ & $2,32 \mathrm{Aab}$ & $2,14 \mathrm{Ab}$ \\
29 agosto & $2,99 \mathrm{Aa}$ & $2,34 \mathrm{Ba}$ & $2,51 \mathrm{Aa}$ & $2,46 \mathrm{Aa}$ \\
3 outubro & $2,7 \mathrm{Aa}$ & $2,45 \mathrm{ABab}$ & $2,11 \mathrm{Aab}$ & $1,73 \mathrm{Ab}$ \\
8 novembro & $2,86 \mathrm{Aa}$ & $2,04 \mathrm{Bb}$ & $2,33 \mathrm{Aab}$ & $2,1 \mathrm{Aab}$ \\
13 dezembro & $3,35 \mathrm{Aa}$ & $3,04 \mathrm{Aab}$ & $2,54 \mathrm{Abc}$ & $2,22 \mathrm{Ac}$ \\
\hline
\end{tabular}

Médias seguidas pela mesma letra, minúscula na linha e maiúscula na coluna, não diferem entre si pelo teste de Tukey a $5 \%$.

Quanto às folhas, no que diz respeito aos graus de sintomatologia, apenas na segunda coleta não ocorreu diferença entre os tratamentos. Nas outras coletas, a 
evolução dos sintomas influenciou no enxofre, como no caso da ultima coleta, onde passou de $3,35 \mathrm{~g} \mathrm{~kg}^{-1}$ nas plantas assintomáticas para $3,04 \mathrm{~g} \mathrm{~kg}^{-1}$ nas plantas com sintomas iniciais, chegando a $2,22 \mathrm{~g} \mathrm{~kg}^{-1}$ nas plantas com sintomas avançados da doença. Apenas no estágio inicial de sintomatologia ocorreram diferenças entre as épocas de amostragem, e essas alterações foram irregulares.

Tabela 21. Concentrações de enxofre na interação entre épocas de coleta e estágios de manifestação de sintomas na planta, na casca do tronco de plantas da variedade Pêra Rio.

\begin{tabular}{ccccccc}
\hline & 0 & \multicolumn{2}{c}{1} & 2 & 3 \\
\hline 24 junho & $0,95 \mathrm{BCab}$ & $0,89 \mathrm{Bab}$ & $0,75 \mathrm{Cb}$ & $1,00 \mathrm{Ba}$ \\
29 agosto & $0,70 \mathrm{Ca}$ & $0,73 \mathrm{Ba}$ & $0,64 \mathrm{Ca}$ & $0,79 \mathrm{Ba}$ \\
3 outubro & $1,11 \mathrm{Ba}$ & $0,89 \mathrm{Ba}$ & $0,91 \mathrm{Ba}$ & $0,99 \mathrm{Ba}$ \\
8 novembro & $0,83 \mathrm{Ca}$ & $0,78 \mathrm{Ba}$ & $0,79 \mathrm{BCa}$ & $0,88 \mathrm{Ba}$ \\
13 dezembro & $1,58 \mathrm{Aa}$ & $1,50 \mathrm{Aa}$ & $1,47 \mathrm{Aa}$ & $1,45 \mathrm{Aa}$ \\
\hline
\end{tabular}

Médias seguidas pela mesma letra, minúscula na linha e maiúscula na coluna, não diferem entre si pelo teste de Tukey a $5 \%$.

Quanto à casca do tronco, no que diz respeito aos graus de sintomatologia, apenas na primeira coleta ocorreu diferença entre os tratamentos, não seguindo uma tendência com a evolução dos sintomas da morte súbita. Em todos os estágios ocorreram diferenças entre as épocas de amostragem, mostrando haver um aumento de enxofre na última época de coleta, como foi observado ao se analisar as épocas de amostragem agrupando todos os estágios da doença.

\subsubsection{Boro}

Ao se analisar a concentração de boro dentro dos estágios de sintomatologia da morte súbita do citros, pode-se observar diferenças do nutriente nas folhas e raízes (Tabela 22). 
Tabela 22. Concentração de boro em plantas de citros, variedade Pêra Rio, e do solo nos estágios da morte súbita do citros

\begin{tabular}{|c|c|c|c|c|c|}
\hline Sintomas & Folhas & $\begin{array}{l}\text { Galhos } \\
-m g\end{array}$ & $\begin{array}{l}\text { Casca do tronco } \\
\text { g }\end{array}$ & Raizes & $\begin{array}{c}\text { Solo } \\
\mathrm{mg} \mathrm{dm}^{-3}\end{array}$ \\
\hline 0 & $44,20 a$ & 14,74 a & 29,28 a & 23,25 a & $0,55 a$ \\
\hline 1 & $35,57 \mathrm{ab}$ & 14,33 a & 29,59 a & $16,85 b$ & $0,50 a$ \\
\hline 2 & $32,07 \quad b$ & 14,95 a & 31,23 a & $16,57 b$ & $0,50 a$ \\
\hline 3 & $34,04 \quad b$ & 14,41 a & 29,92 a & $16,54 \mathrm{~b}$ & $0,51 \mathrm{a}$ \\
\hline
\end{tabular}

À medida que os sintomas evoluíram, as concentrações de boro nas folhas diminuíram, mostrando diferenciações nutricionais entre as plantas assintomáticas e sintomáticas. O nutriente passou de $44,20 \mathrm{mg} \mathrm{kg}^{-1}$ nas plantas assintomáticas para $35,57 \mathrm{mg} \mathrm{kg}^{-1}$ nas plantas no primeiro estágio de sintomatologia da morte súbita do citros, chegando a $32,07 \mathrm{mg} \mathrm{kg}^{-1}$ nas folhas de plantas em estágio intermediário da doença. Em um experimento realizado no Brasil por Coelho et al. (1983), onde se analisou a concentração nutricional das folhas de citros, cv. Valência com o avanço do declínio, observou-se que ocorreu um aumento da concentração do boro com a doença.

Segundo Violante Netto et al. (1988) e Rodrigues et al.(1991), a concentração de boro adequado nas folhas de citros geradas na primavera, com seis meses de idade, de ramos com fruto é de $36,00-100,00 \mathrm{mg} \mathrm{kg}^{-1}$, que quando comparada com a média das coletas realizadas de $36,47 \mathrm{mg} \mathrm{kg}^{-1} \mathrm{e}$ nas plantas assintomáticas que apresentaram $44,20 \mathrm{mg} \mathrm{kg}^{-1}$ de boro, resulta nos dois casos em valores considerados adequados. Segundo Malavolta \& Prates (1994), no entanto, a concentração adequada de boro, para esta época é de $60,00-140,00 \mathrm{mg} \mathrm{kg}^{-1}$, mostrando assim que o nutriente se encontra em deficiência. E esses mesmo autores indicam $60,00-120,00 \mathrm{mg} \mathrm{kg}^{-1}$ como adequado para a época de coleta do experimento.

Nas raizes a alteração do nutriente ocorreu da mesma maneira, isto é, apenas as plantas assintomáticas diferenciaram dos demais estágios da morte súbita. $O$ boro decresceu de $23,25 \mathrm{mg} \mathrm{kg}^{-1}$ nas plantas assintomáticas para $16,85 \mathrm{mg} \mathrm{kg}^{-1}$ nas plantas que se apresentavam no primeiro grau de sintomatologia da doença.

Esse nutriente, juntamente com o cálcio, são os dois principais responsáveis pela formação do sistema radicular, por constituirem a parede celular (Marschner, 1997 e Malavolta, 1980). Sendo assim, a sua queda pode provocar uma diminuição no 
volume de raízes, principalmente de radicelas, que são as principais responsáveis pela absorção de nutrientes pela planta.

As alterações que ocorreram com o boro nas folhas e raízes com a evolução da sintomatologia não têm relação com seu teor no solo, já que este permaneceu praticamente inalterado, com a evolução dos sintomas, sendo considerado adequado (Raij et al., 1996).

Quanto às épocas de coletas pode-se observar que as concentrações de boro foram afetadas nas folhas, galhos e raizes (Tabela 23).

Tabela 23. Concentrações de boro em plantas de citros, variedade Pêra Rio, e do solo nas épocas de coleta.

\begin{tabular}{|c|c|c|c|c|c|}
\hline Coletas & Folhas & Galhos & $\begin{array}{l}\text { Casca do tronco } \\
\mathrm{kg}^{-1}\end{array}$ & Raízes & $\begin{array}{c}\text { Solo } \\
\mathrm{mg} \mathrm{dm}^{-3}\end{array}$ \\
\hline 24 junho & 44,23 a & $17,30 a$ & 32,78 a & $20,12 a b$ & $0,54 a$ \\
\hline 29 agosto & 39,54 a & $12,61 \mathrm{~b}$ & 27,17 a & $18,86 a b$ & $0,50 \mathrm{a}$ \\
\hline 3 outubro & 39,88 a & 17,64 a & 32,75 a & 21,68 a & $0,46 a$ \\
\hline 8 novembro & $30,71 \quad b$ & $13,06 a b$ & 30,43 a & $16,01 a b$ & $0,52 a$ \\
\hline 13 dezembro & $27,98 \mathrm{~b}$ & $12,44 \quad b$ & $26,89 \quad a$ & $14,83 \mathrm{~b}$ & 0,56 a \\
\hline
\end{tabular}

As concentrações de boro nas folhas foram menores nas duas últimas coletas, ocorrendo uma queda acentuada, passando de $44,23 \mathrm{mg} \mathrm{kg}^{-1}$ na primeira coleta para $30,71 \mathrm{mg} \mathrm{kg}^{-1}$ e $27,98 \mathrm{mg} \mathrm{kg}{ }^{-1}$ na quarta e quinta coletas respectivamente. Essa tendência nutricional ocorreu de maneira semelhante com as raizes, onde o nutriente passou de $20,12 \mathrm{mg} \mathrm{kg}^{-1}$ na primeira coleta para $16,01 \mathrm{mg} \mathrm{kg}^{-1}$ e $14,83 \mathrm{mg} \mathrm{kg}^{-1}$ na quarta e quinta coleta respectivamente. Pode-se inferir que à medida que o boro foi decrescendo nas raízes, isto também ocorreu nas folhas devido ao nutriente não possuir redistribuição na planta. Isso ocorre pois as folhas não possuiam outras fontes do nutriente na planta, a não ser das raízes a partir do xilema (Marschner, 1997; Violante Netto et al., 1988).

Em relação à alteração nutricional do referido nutriente nos galhos, não se pode inferir nada por ser uma alteração irregular, que não seguiu nenhuma tendência. Quanto ao solo, o boro não mostrou alterações com o passar das coletas, não influenciando assim, nas quedas das concentrações das raizes ou folhas.

Quanto à interação entre época de amostragem e estágios de sintomatologia da doença, esta ocorreu nas folhas (Tabela 24). 
Tabela 24. Concentrações de boro na interação entre épocas de coleta e estágios de manifestação de sintomas na planta, nas folhas de plantas da variedade Pêra Rio

\begin{tabular}{crrrrr}
\hline & 0 & & 1 & 2 & 3 \\
\hline 24 junho & $49,28 \mathrm{Aa}$ & $44,35 \mathrm{Aa}$ & $44,05 \mathrm{Aa}$ & $39,25 \mathrm{Aa}$ \\
29 agosto & $42,08 \mathrm{Aa}$ & $34,28 \mathrm{Aa}$ & $40,52 \mathrm{Aa}$ & $41,28 \mathrm{Aa}$ \\
3 outubro & $43,67 \mathrm{Aa}$ & $43,72 \mathrm{Aa}$ & $34,74 \mathrm{Aa}$ & $37,37 \mathrm{Aa}$ \\
8 novembro & $43,91 \mathrm{Aa}$ & $26,68 \mathrm{Aab}$ & $24,55 \mathrm{ABb}$ & $27,71 \mathrm{Aab}$ \\
13 dezembro & $42,07 \mathrm{Aa}$ & $28,8 \mathrm{Aab}$ & $16,49 \mathrm{Bb}$ & $24,57 \mathrm{Aab}$ \\
\hline
\end{tabular}

Médias seguidas pela mesma letra, minúscula na linha e maiúscula na coluna, não diferem entre si pelo teste de Tukey a $5 \%$.

Apenas no estágio intermediário da doença ocorreram diferenças entre as diversas épocas de amostragem, mostrando uma queda na concentração do nutrientè com o passar das coletas, passando de $44,05 \mathrm{mg} \mathrm{kg}^{-1}$ na primeira coleta para 24,55 $\mathrm{mg} \mathrm{kg}^{-1}$ e 16,49 $\mathrm{mg} \mathrm{kg}^{-1}$ na quarta e quinta coleta respectivamente. Somente na quarta e quinta coletas ocorreram diferenças entre os estágios de sintomatologia da morte súbita, havendo uma queda nutricional com a evolução da doença.

\subsubsection{Cobre}

Ao se analisar a concentração de cobre dentro dos estágios de sintomatologia da morte súbita do citros, pode-se observar diferenças do nutriente nas folhas e galhos (Tabela 25).

Tabela 25. Concentrações de cobre em plantas de citros, variedade Pêra Rio, e do solo nos estágios da morte súbita do citros

\begin{tabular}{|c|c|c|c|c|c|c|}
\hline Sintomas & Folhas & $\begin{array}{l}\text { Galhos } \\
\text { mg }\end{array}$ & $\begin{array}{l}\text { Casca do tronco } \\
\mathrm{g}^{-1}\end{array}$ & Raízes & $\begin{array}{c}\text { Solo } \\
\mathrm{mg} \mathrm{dm}^{-3}\end{array}$ & \\
\hline 0 & $85,03 b$ & $68,81 \mathrm{~b}$ & 39,87 a & 15,57 a & 7,06 & a \\
\hline 1 & $108,78 a$ & $81,84 a b$ & $26,81 \quad a$ & 11,09 a & 7,47 & a \\
\hline 2 & $98,14 a b$ & $91,26 a b$ & $26,79 a$ & 17,84 a & 7,81 & a \\
\hline 3 & $85,44 b$ & 118,49 a & 28,98 a & 19,88 a & 6,95 & a \\
\hline
\end{tabular}

À medida que os sintomas evoluíram, as concentrações de cobre nos galhos aumentaram, mostrando diferenciações nutricionais entre as plantas assintomáticas e sintomáticas. O nutriente passou de $68,81 \mathrm{mg} \mathrm{kg}^{-1}$ nas plantas assintomáticas para $91,26 \mathrm{mg} \mathrm{kg}^{-1}$ nas plantas em estágio intermediário, chegando a $118,49 \mathrm{mg} \mathrm{kg}^{-1}$ nas 
plantas no último estágio de sintomatologia da morte súbita do citros. Esse aumento do nutriente pode ser devido à diminuição da massa seca da planta, isto é, queda de folhas e menor desenvolvimento da parte aérea e sistema radicular, e um conseqüente acúmulo de cobre nessa parte da planta (Pivetta, 2003; Fundecitrus, 2002a).

As folhas tiveram alteração do nutriente de forma irregular, mostrando um aumento de cobre no início, sendo que a concentração passou de $85,03 \mathrm{mg} \mathrm{kg}^{-1} \mathrm{em}$ plantas assintomáticas para $108,78 \mathrm{mg} \mathrm{kg}^{-1} \mathrm{em}$ plantas no primeiro estágio da doença, e posterior queda com a evolução da doença, $98,14 \mathrm{mg} \mathrm{kg}^{-1}$ em plantas no estágio intermediário e $85,44 \mathrm{mg} \mathrm{kg}^{-1}$ na última fase da doença. Quando se compara, no entanto, o avanço do declínio do citros com a concentração de cobre nas folhas podese observar aumento do mesmo (Wutscher \& Hardesty, 1979 e Coelho et al., 1983).

Segundo Violante Netto et al. (1988) e Rodrigues et al. (1991), a concentração de cobre adequada nas folhas de citros geradas na primavera, com seis meses de idade, de ramos com fruto é de 5,00-12,00 $\mathrm{mg} \mathrm{kg}^{-1}$, que quando comparada com a média das coletas realizadas de $94,35 \mathrm{mg} \mathrm{kg}^{-1} \mathrm{e}$ das plantas assintomáticas que apresentaram $85,03 \mathrm{mg} \mathrm{kg}^{-1}$, resulta nos dois casos em concentrações acima da ideal. Considerando-se a concentração adequada para época coletada de 10,00 - 30,00 mg $\mathrm{kg}^{-1}$ (Malavolta \& Prates, 1994), o nutriente ainda se encontra acima do adequado.

As alterações que ocorreram com o cobre nas folhas e galhos, com a evolução da sintomatologia, não tiveram relação com seu teor no solo, devido à não alteração do nutriente no solo com a evolução da doença, sendo este considerado alto (Raij et al., 1996).

Quanto às épocas de coletas pode-se observar que as concentrações de cobre foram afetadas em todas as partes da planta: folhas, galhos, casca do tronco e raízes (Tabela 26). 
Tabela 26. Concentrações de cobre em plantas de citros, variedade Pêra Rio, e do solo nas épocas de coleta

\begin{tabular}{crrrrrr}
\hline Coletas & Folhas & Galhos & \multicolumn{2}{c}{ Casca do tronco } & Raizes & $\begin{array}{r}\text { Solo } \\
\mathrm{mg} \mathrm{dm}^{-3}\end{array}$ \\
\hline 24 junho & $13,31 \mathrm{c}$ & $28,26 \mathrm{c}$ & $29,99 \mathrm{ab}$ & $27,30 \mathrm{a}$ & $5,38 \mathrm{c}$ \\
29 agosto & $9,24 \mathrm{c}$ & $30,80 \mathrm{c}$ & $20,61 \mathrm{~b}$ & $15,84 \mathrm{ab}$ & $9,48 \mathrm{a}$ \\
3 outubro & $111,69 \mathrm{~b}$ & $89,01 \mathrm{~b}$ & $37,18 \mathrm{a}$ & $12,66 \mathrm{~b}$ & $6,23 \mathrm{~b}$ \\
8 novembro & $235,94 \mathrm{a}$ & $156,03 \mathrm{a}$ & $33,10 \mathrm{ab}$ & $9,83 \mathrm{~b}$ & $7,99 \mathrm{a}$ \\
13 dezembro & $101,55 \mathrm{a}$ & $146,40 \mathrm{a}$ & $32,18 \mathrm{ab}$ & $14,84 \mathrm{ab}$ & $7,64 \mathrm{ab}$ \\
\hline
\end{tabular}

As concentrações de cobre nas folhas foram alteradas nas três últimas coletas, ocorrendo um aumento acentuado do nutriente. Esse aumento, como já foi dito, pode ter ocorrido devido à aplicação de algum defensivo cúprico. O cobre nas folhas passou de $13,31 \mathrm{mg} \mathrm{kg}^{-1}$ e 9,24 $\mathrm{mg} \mathrm{kg}^{-1}$, na primeira e segunda coleta respectivamente, para $111,69 \mathrm{mg} \mathrm{kg}^{-1}$ na terceira coleta, atingindo um pico de $235,94 \mathrm{mg} \mathrm{kg}^{-1}$ na quarta coleta. Essa tendência ocorreu também nos galhos, no entanto de uma maneira menos acentuada, no qual o cobre passou de $28,26 \mathrm{mg} \mathrm{kg}^{-1}$ na primeira coleta, para um máximo de $156,03 \mathrm{mg} \mathrm{kg}^{-1}$ na quarta coleta.

Como esse nutriente tem mobilidade impedida quanto à redistribuição a sua concentração na casca do tronco e raízes não seguiram a mesma tendência (Marschner, 1997). Nas raízes, chegou até a diminuição com o passar das coletas passando de $27,30 \mathrm{mg} \mathrm{kg}^{-1}$ na primeira coleta para $9,83 \mathrm{mg} \mathrm{kg}^{-1}$ na quarta coleta. Podendo ter ocorrido uma maior dificuldade de absorção do nutriente pelas raízes, por motivo de competição ou então um deslocamento do mesmo para a parte aérea.

O solo mostrou alterações com o passar das coletas, no entanto, essas alterações não seguiram uma tendência, não sendo possível a associação do cobre no solo com seu desempenho na planta.

Quanto à interação entre época de amostragem e estágios de sintomatologia da doença, esta ocorreu nos galhos (Tabela 27). 
Tabela 27. Concentrações de cobre na interação entre épocas de coleta e estágios de manifestação de sintomas na planta, nos galhos de plantas da variedade Pêra Rio

\begin{tabular}{crrrrr}
\hline & 0 & \multicolumn{1}{c}{1} & \multicolumn{1}{c}{2} & \multicolumn{1}{c}{3} \\
\hline 24 junho & $16,4 \mathrm{Ba}$ & $26,08 \mathrm{Ba}$ & $35,65 \mathrm{Ba}$ & $34,9 \mathrm{Ca}$ \\
29 agosto & $24,75 \mathrm{Ba}$ & $37,93 \mathrm{Ba}$ & $35,3 \mathrm{Ba}$ & $25,23 \mathrm{Ca}$ \\
3 outubro & $63,15 \mathrm{ABa}$ & $80,83 \mathrm{ABa}$ & $98,85 \mathrm{ABa}$ & $113,23 \mathrm{Ba}$ \\
8 novembro & $116,18 \mathrm{Ab}$ & $138,53 \mathrm{Ab}$ & $134,63 \mathrm{Ab}$ & $234,8 \mathrm{Aa}$ \\
13 dezembro & $123,58 \mathrm{Aa}$ & $125,85 \mathrm{Aa}$ & $151,88 \mathrm{Aa}$ & $184,3 \mathrm{Ba}$ \\
\hline
\end{tabular}

Médias seguidas pela mesma letra, minúscula na linha e maiúscula na coluna, não diferem entre si pelo teste de Tukey a $5 \%$.

Nas épocas de amostragem ocorreram aumentos das concentrações de cobre nos galhos, a partir da terceira coleta em todos os estágios de sintomatologia da morte súbita. Esse aumento pode ser devido à aplicação de algum defensivo agrícola entre a segunda e terceira coleta que influenciou o aumento do nutriente. Quanto aos estágios de sintomatologia apenas na quarta coleta houve diferença entre os tratamentos, ocorrendo um aumento do nutriente com a evolução da doença.

\subsubsection{Ferro}

Ao se analisar as concentrações de ferro dentro dos estágios de sintomatologia da morte súbita do citros, pode-se observar diferenças do nutriente nos galhos, casca do tronco e raizes (Tabela 28 ).

Tabela 28. Concentrações de ferro em plantas de citros, variedade Pêra Rio, e do solo nos estágios da morte súbita do citros

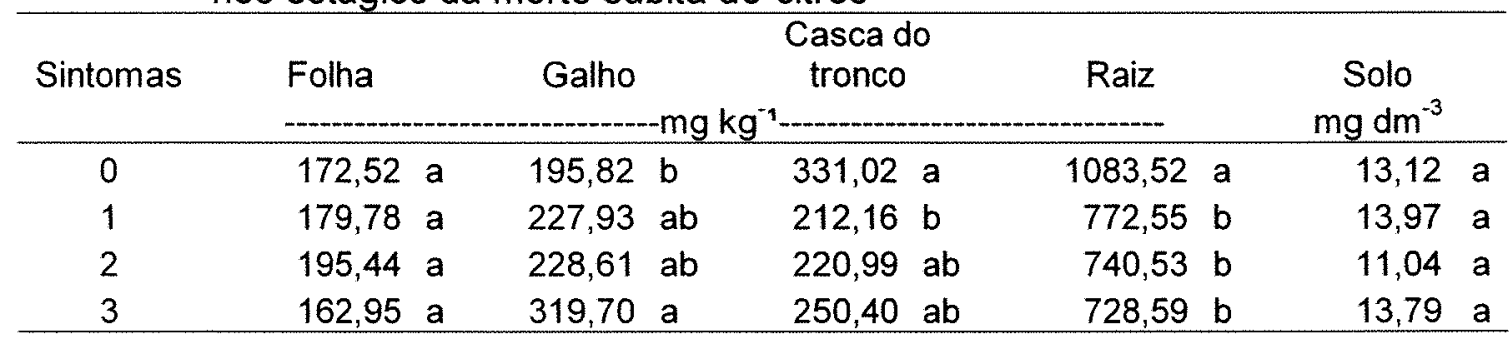

À medida que os sintomas evoluíram, as concentrações de ferro nos galhos aumentaram, mostrando diferenciações nutricionais entre as plantas assintomáticas e sintomáticas. O nutriente passou de $195,82 \mathrm{mg} \mathrm{kg}^{-1}$ nas plantas assintomáticas para 
$319,70 \mathrm{mg} \mathrm{kg}^{-1}$ nas plantas no último estágio de sintomatologia da morte súbita do citros.

No entanto, nas raizes e na casca do tronco ocorreu uma diminuição do ferro à medida que os sintomas se intensificavam. Na casca do tronco o ferro passou de $331,02 \mathrm{mg} \mathrm{kg}^{-1}$ nas plantas assintomáticas para $212,16 \mathrm{mg} \mathrm{kg}^{-1}$ nas plantas no primeiro estágio de sintomatologia. Nas raízes, ocorreu a mesma tendência, onde o ferro passou de $1083,52 \mathrm{mg} \mathrm{kg}^{-1}$ nas plantas assintomáticas para $772,55 \mathrm{mg} \mathrm{kg}^{-1}$ nas plantas que apresentaram sintomas inicias da doença. No solo não ocorreu alteração do ferro com o desenvolvimento da sintomatologia da doença, tendo sido considerado adequado no solo (Raij et al., 1996).

O aumento do nutriente nos galhos pode ser devido à diminuição da massa seca da planta, isto é, à queda de folhas, ausência de brotações internas, poucas brotações externas e menor desenvolvimento sistema radicular, e o conseqüente acúmulo de ferro nessa parte da planta (Pivetta, 2003 e Fundecitrus, 2002a). Ou então pode ter ocorrido uma migração do nutriente, das raizes e casca do tronco para os galhos à medida que a doença evolui, como um mecanismo de sobrevivência da planta.

Não ocorreu alteração do nutriente nas folhas das plantas, com a evolução da morte súbita, no entanto, quando se compara com plantas afetadas com clorose variegada dos citros nota-se nestas, um aumento da concentração do referido nutriente com o avanço da doença (Ricci et al., 2001).

Segundo Violante Netto et al. (1988) e Rodrigues et al. (1991), a concentração de ferro adequada nas folhas de citros geradas na primavera, com seis meses de idade, de ramos com fruto é de $50-120 \mathrm{mg} \mathrm{kg}^{-1}$, que quando comparada com a média das coletas realizadas de $178,42 \mathrm{mg} \mathrm{kg}^{-1} \mathrm{e}$ das plantas assintomáticas que apresentaram $172,52 \mathrm{mg} \mathrm{kg}^{-1}$ de ferro, resulta nos dois casos em valores considerados adequados. No entanto Malavolta \& Prates (1994), citam como valores adequados para esta época de 130,00 - 300,00 $\mathrm{mg} \mathrm{kg}^{-1}$, mostrando assim que os valores encontrados estão adequados. Considerando-se a concentração adequada para a época da coleta no experimento de 200,00 - 300,00 $\mathrm{mg} \mathrm{kg}^{-1}$ (Malavolta \& Prates, 1994), os valores encontrados estavam adequados. 
Quanto às épocas de coletas, notou-se que as concentrações de ferro foram afetadas em todas as partes da planta: folhas, galhos, casca do tronco e raízes (Tabela 29).

Tabela 29. Concentrações de ferro em plantas de citros, variedade Pêra Rio, e do solo nas épocas de coleta

\begin{tabular}{|c|c|c|c|c|c|c|}
\hline Coletas & Folhas & Galhos & $-\mathrm{mg}$ & $\begin{array}{l}\text { Casca do tronco } \\
\mathrm{kg}^{-1}\end{array}$ & Raizes & $\begin{array}{c}\text { Solo } \\
\mathrm{mg} \mathrm{dm}^{-3}\end{array}$ \\
\hline 24 junho & $223,27 \quad a$ & 164,24 & $b$ & 288,52 bc & 348,12 b & 14,50 a \\
\hline 29 agosto & $119,57 b$ & 161,77 & $b$ & $165,83 c$ & $988,58 \quad a$ & 11,89 a \\
\hline 3 outubro & $233,23 a$ & 345,63 & $a$ & $307,19 a b$ & 959,06 a & 12,42 a \\
\hline 8 novembro & $215,63 a$ & 353,85 & $a$ & 330,63 a & 1094,58 a & 12,64 a \\
\hline 13 dezembro & $96,67 \mathrm{~b}$ & 189,58 & $b$ & $176,04 \mathrm{bc}$ & 766,15 a & 13,08 a \\
\hline
\end{tabular}

As concentrações de ferro em todas as partes analisadas da planta alteraram irregularmente com o passar do tempo, não existindo uma tendência de decréscimo ou acréscimo de ferro, nem a possibilidade de estar ocorrendo redistribuição do nutriente nas diversas partes da planta com o tempo. Pode ter ocorrido uma maior disponibilidade do nutriente depois do início das chuvas quando o $\mathrm{Fe}^{+3}$ se reduziu para $\mathrm{Fe}^{+2}$, aumentando sua solubilidade (Havlin et al., 1999 e Malavolta, 1980).

\subsubsection{Manganês}

Ao se analisar as concentrações de manganês dentro dos estágios de sintomatologia da morte súbita do citros, ocorreram diferenças do nutriente nas folhas, nos galhos e na casca do tronco (Tabela 30).

Tabela 30. Concentrações de manganês em plantas de citros, variedade Pêra Rio, e do solo nos estágios da morte súbita do citros

\begin{tabular}{|c|c|c|c|c|c|c|}
\hline Sintomas & Folhas & Galhos & $\begin{array}{l}\text { Casca do tronco } \\
\mathrm{gg}^{-1}\end{array}$ & Raizes & $\begin{array}{c}\text { Solo } \\
\mathrm{mg} \mathrm{dm}^{-3}\end{array}$ & \\
\hline 0 & $48,83 a b$ & $15,13 \mathrm{~b}$ & 21,00 a & 19,97 a & 23,48 & a \\
\hline 1 & 53,30 a & $18,51 \mathrm{~b}$ & $15,30 \mathrm{~b}$ & 15,94 a & 22,70 & a \\
\hline 2 & $47,62 a b$ & $19,59 \mathrm{~b}$ & $15,84 a b$ & 16,86 a & 21,90 & a \\
\hline 3 & $41,70 \mathrm{~b}$ & 29,52 a & $17,42 a b$ & 17,77 a & 20,26 & a \\
\hline
\end{tabular}

À medida que os sintomas evoluíram, as concentrações de manganês nos galhos aumentaram, mostrando diferenciações nutricionais entre as plantas no último 
estágio da doença e os demais estágios. O nutriente aumentou de $15,13 \mathrm{mg} \mathrm{kg}^{-1}$, nas plantas assintomáticas, para $29,52 \mathrm{mg} \mathrm{kg}^{-1}$ nas plantas no último estágio de sintomatologia da morte súbita do citros. Este aumento do nutriente nos galhos pode ser devido à diminuição da massa seca da planta, isto é, à queda de folhas e ao menor desenvolvimento da parte aérea e sistema radicular, e o acúmulo de manganês conseqüente nessa parte da planta (Pivetta, 2003 e Fundecitrus, 2002a). Ou então pode ter ocorrido uma migração do nutriente, da casca do tronco para os galhos à medida que a doença evolui, como ocorreu com o ferro.

$\mathrm{Na}$ casca do tronco ocorreu uma diminuição do manganês à medida que os sintomas se intensificaram. O manganês passou de $21,00 \mathrm{mg} \mathrm{kg}^{-1}$ nas plantas assintomáticas para $15,30 \mathrm{mg} \mathrm{kg}^{-1}$ nas plantas no primeiro estágio de sintomatologia. Ao comparar com o declínio, Albrigo \& Willians (1984) observaram aumento na concentração de manganês no tronco de plantas com o avanço da doença.

As folhas tiveram alteração do nutriente de forma irregular, mostrando um aumento de manganês no início, sendo que a concentração de manganês passou de $48,83 \mathrm{mg} \mathrm{kg}^{-1} \mathrm{em}$ plantas assintomáticas para $53,30 \mathrm{mg} \mathrm{kg}^{-1} \mathrm{em}$ plantas no primeiro estágio da doença, e posterior queda com a evolução da doença, $47,62 \mathrm{mg} \mathrm{kg}^{-1} \mathrm{em}$ plantas no estágio intermediário e $41,70 \mathrm{mg} \mathrm{kg}^{-1}$ na última fase da doença. A aplicação do adubo foliar entre a segunda e terceira coleta pode ter alterado algum resultado, mascarando a evolução real do manganês nas folhas. Em experimento realizado com o declínio do citros observou-se que a concentração de manganês diminuiu com o avanço da doença (Tavares, 1987). Quando se observou o manganês em folhas de plantas afetadas pela clorose variegada do citros, notou-se um aumento da concentração do nutriente com o avanço da doença (Ricci et al., 2001).

Segundo Violante Netto et al. (1988) e Rodrigues et al. (1991), a concentração de manganês adequada nas folhas de citros geradas na primavera, com seis meses de idade, de ramos com fruto é de $25,00-49,00 \mathrm{mg} \mathrm{kg}^{-1}$, que quando comparada com a média das coletas realizadas de $47,86 \mathrm{mg} \mathrm{kg}^{-1}$ e das plantas assintomáticas que apresentaram $48,83 \mathrm{mg} \mathrm{kg}^{-1}$ de cobre, resulta nos dois casos em valores considerados adequados. Considerando-se a concentração adequada para a época coletada do experimento de $25,00-50,00 \mathrm{mg} \mathrm{kg}^{-1}$ (Malavolta \& Prates, 1994) o manganês continuou adequado. 
No solo não houve alteração do teor do nutriente com o aumento da sintomatologia da doença, sendo considerado alto no solo, onde o teor ideal é de 5,0 $\mathrm{mg} \mathrm{dm}^{-3}$ (Raij et al., 1996).

Quanto às épocas de coleta, notou-se que as concentrações de manganês foram afetadas nas folhas e nos galhos (Tabela 31 ).

Tabela 31. Concentrações de manganês em plantas de citros, variedade Pêra Rio, e do solo nas épocas de coleta

\begin{tabular}{ccccccc}
\hline Coletas & Folhas & Galhos & Casca do tronco & Raizes & $\begin{array}{c}\text { Solo } \\
\mathrm{mg} \mathrm{dm}^{-3}\end{array}$ \\
\hline 24 junho & $44,13 \mathrm{bc}$ & $14,09 \mathrm{~b}$ & $18,39 \mathrm{a}$ & $19,53 \mathrm{a}$ & $24,14 \mathrm{~b}$ \\
29 agosto & $40,49 \mathrm{c}$ & $17,46 \mathrm{~b}$ & $15,18 \mathrm{a}$ & $16,23 \mathrm{a}$ & $28,52 \mathrm{a}$ \\
3 outubro & $49,05 \mathrm{abc}$ & $20,28 \mathrm{ab}$ & $18,47 \mathrm{a}$ & $16,06 \mathrm{a}$ & $19,70 \mathrm{c}$ \\
8 novembro & $56,32 \mathrm{a}$ & $29,31 \mathrm{a}$ & $18,80 \mathrm{a}$ & $16,96 \mathrm{a}$ & $19,36 \mathrm{~cd}$ \\
13 dezembro & $49,33 \mathrm{ab}$ & $22,28 \mathrm{ab}$ & $16,11 \mathrm{a}$ & $19,39 \mathrm{a}$ & $16,27 \mathrm{~d}$ \\
\hline
\end{tabular}

O manganês nas folhas foi alterado nas três últimas coletas, ocorrendo um aumento acentuado do referido nutriente devido, provavelmente, à aplicação do adubo foliar que continha manganês, entre a segunda e terceira coletas. O manganês passou de $44,13 \mathrm{mg} \mathrm{kg}^{-1}$ e 40,49 $\mathrm{mg} \mathrm{kg}^{-1}$, na primeira e segunda coleta respectivamente, para $49,05 \mathrm{mg} \mathrm{kg}^{-1}$ na terceira coleta, atingindo um pico de $56,32 \mathrm{mg} \mathrm{kg}^{-1}$ na quarta coleta.

Essa aplicação refletiu nos galhos, nos quais o manganês era de $14,09 \mathrm{mg} \mathrm{kg}^{-1}$, na primeira coleta, chegando a um máximo de $29,31 \mathrm{mg} \mathrm{kg}^{-1}$ na quarta coleta. Como esse nutriente tem uma mobilidade impedida quanto à redistribuição, sua concentração na casca do tronco e raízes não seguiram a mesma tendência (Marschner, 1997 e Malavolta, 1980).

Quanto ao seu teor no solo, ocorreram alterações no nutriente com o passar do tempo, no entanto, essas alterações tiveram comportamento oposto ao das folhas e dos galhos, isto é, o teor de manganês diminuiu a partir da segunda coleta. No entanto, essa diminuição não afetou nenhuma parte da planta.

Quanto à interação entre época de amostragem e estágios de sintomatologia da doença, esta ocorreu nos galhos (Tabela 32). 
Tabela 32. Concentrações de manganês na interação entre épocas de coleta e estágios de manifestação de sintomas na planta, nos galhos de plantas da variedade Pêra Rio

\begin{tabular}{crrrrr}
\hline & 0 & 1 & 2 & \multicolumn{1}{c}{3} \\
\hline 24 junho & $11,83 \mathrm{Aa}$ & $12,98 \mathrm{Aa}$ & $13,7 \mathrm{Aa}$ & $17,85 \mathrm{BCa}$ \\
29 agosto & $14,28 \mathrm{Aa}$ & $21,78 \mathrm{Aa}$ & $19,48 \mathrm{Aa}$ & $14,33 \mathrm{Ca}$ \\
3 outubro & $16,2 \mathrm{Aa}$ & $17,43 \mathrm{Aa}$ & $21,38 \mathrm{Aa}$ & $26,1 \mathrm{BCa}$ \\
8 novembro & $19,45 \mathrm{Ab}$ & $24,28 \mathrm{Ab}$ & $22,45 \mathrm{Ab}$ & $51,07 \mathrm{Aa}$ \\
13 dezembro & $13,88 \mathrm{Ab}$ & $16,08 \mathrm{Aab}$ & $20,95 \mathrm{Aab}$ & $38,23 \mathrm{ABa}$ \\
\hline
\end{tabular}

Médias seguidas pela mesma letra, minúscula na linha e maiúscula na coluna, não diferem entre si pelo teste de Tukey a $5 \%$.

Quanto às épocas de coleta, ocorreu diferença apenas no último estágio de sintomatologia da doença, onde nas duas ultimas coletas observou-se aumentos significativos do nutriente, sendo que o manganês passou de $17,85 \mathrm{mg} \mathrm{kg}^{-1}$ e $14,33 \mathrm{mg}$ $\mathrm{kg}^{-1}$ na primeira e segunda coletas, respectivamente para $51,07 \mathrm{mg} \mathrm{kg}^{-1}$ na quarta $\mathrm{e}$ $38,23 \mathrm{mg} \mathrm{kg}^{-1}$ na quinta coleta. Nos estágios da morte súbita, nota-se um aumento do nutriente nos galhos com o decorrer da sintomatologia da morte súbita apenas na quarta e na quinta coletas, sendo que nas coletas anteriores não ocorreram diferenças entre as concentrações do nutriente nos galhos analisados.

\subsubsection{Zinco}

Ao se analisar as concentrações de zinco dentro dos estágios de sintomatologia da morte súbita do citros, nota-se diferenças do nutriente nas folhas, galhos e raízes (Tabela 33).

Tabela 33. Concentrações de zinco em plantas de citros, variedade Pêra Rio, e do solo nos estágios da morte súbita do citros

\begin{tabular}{|c|c|c|c|c|c|}
\hline Sintomas & Folhas & $\begin{array}{l}\text { Galhos } \\
-m g\end{array}$ & $\begin{array}{l}\text { Casca do tronco } \\
g^{-1}-\ldots\end{array}$ & Raízes & $\begin{array}{c}\text { Solo } \\
\mathrm{mg} \mathrm{dm}^{-3}\end{array}$ \\
\hline 0 & $38,99 \mathrm{~b}$ & $35,34 \mathrm{~b}$ & $64,71 \mathrm{a}$ & $110,73 a$ & 4,17 a \\
\hline 1 & $47,04 a b$ & $43,78 \mathrm{~b}$ & 54,84 a & $53,22 \mathrm{~b}$ & 4,57 a \\
\hline 2 & 51,54 a & $44,88 \mathrm{~b}$ & $50,64 a$ & $47,21 \mathrm{~b}$ & $5,16 a$ \\
\hline 3 & $45,68 \mathrm{ab}$ & 59,23 a & 54,03 a & $58,07 \mathrm{~b}$ & $4,57 \quad a$ \\
\hline
\end{tabular}

À medida que os sintomas evoluíram, as concentrações de zinco nos galhos aumentaram, mostrando diferenciações nutricionais entre as plantas no último estágio 
da doença e os demais estágios. O nutriente aumentou de $35,34 \mathrm{mg} \mathrm{kg}^{-1}$ nas plantas assintomáticas para $59,23 \mathrm{mg} \mathrm{kg}^{-1}$ nas plantas no último estágio de sintomatologia da morte súbita do citros. Esse nutriente nos galhos, teve comportamento igual ao cobre, ferro e manganês, que são micronutrientes metálicos. Esse aumento pode ser devido à menor quantidade de massa seca da planta que ocorreu devido à queda de folhas e ao menor desenvolvimento da parte aérea e do sistema radicular, e o conseqüente acúmulo de zinco nessa parte da planta (Pivetta, 2003 e Fundecitrus, 2002a). Ou então pode ter ocorrido uma migração do nutriente, das raízes para parte aérea à medida que a doença evolui, ou ainda devido à aplicação do adubo foliar entre a segunda e terceira coleta.

Nas raízes, ocorreu uma diminuição do zinco com o aparecimento de sintomas da doença. O zinco passou de $110,73 \mathrm{mg} \mathrm{kg}^{-1}$ nas plantas assintomáticas para 53,22 $\mathrm{mg} \mathrm{kg}^{-1}$ nas plantas no primeiro estágio da morte súbita do citros. No solo não houve alteração do nutriente, sendo que este foi considerado adequado (Raij et al., 1996).

Quanto à concentração de zinco na casca do tronco, não ocorreu alteração com o avanço da morte súbita. No entanto, quando avaliou a concentração de zinco no tronco, com o avanço do declínio do citros, ocorreu um aumento do mesmo nesta parte da planta (Albrigo \& Young, 1979 e Willians \& Albrigo, 1984).

As folhas tiveram alteração da concentração do nutriente de forma irregular, mostrando um aumento de zinco, de $38,99 \mathrm{mg} \mathrm{kg}^{-1} \mathrm{em}$ plantas assintomáticas para $51,54 \mathrm{mg} \mathrm{kg}^{-1}$ em plantas no estágio intermediário da doença, e posterior queda com a morte da planta chegando a 45,68 $\mathrm{mg} \mathrm{kg}^{-1}$ na última fase da doença. Mostrando assim, uma diferenciação das plantas assintomáticas para as plantas com sintoma. No experimento realizado com declínio do citros, a concentração de zinco também aumentou com o desenvolvimento da doença (Wutscher \& Hardesty, 1979).

Segundo Violante Netto et al. (1988) e Rodrigues et al. (1991), a concentração de zinco adequada nas folhas de citros geradas na primavera, com seis meses de idade, de ramos com fruto é de $25-49 \mathrm{mg} \mathrm{kg}^{-1}$, que quando comparada com a média das coletas realizadas de $45,81 \mathrm{mg} \mathrm{kg}^{-1}$ e das plantas assintomáticas que apresentaram $38,99 \mathrm{mg} \mathrm{kg}^{-1}$ de zinco, resulta nos dois casos em valores considerados adequados. Considerando-se a concentração adequada para a época coletada de 25,00-50,00 $\mathrm{mg} \mathrm{kg}^{-1}$ (Malavolta \& Prates, 1994), os valores analisados continuaram adequados. 
Quanto às épocas de coleta, nota-se que as concentrações de zinco foram afetadas em todas as partes da planta (folhas, galhos, casca do tronco e raízes) (Tabela 34).

Tabela 34. Concentrações de zinco em plantas de citros, variedade Pêra Rio, e do solo nas épocas de coleta

\begin{tabular}{ccccccc}
\hline Coletas & Folhas & Galhos & $\begin{array}{c}\text { Casca do tronco } \\
\text { Raizes }\end{array}$ & $\begin{array}{c}\text { Solo } \\
\text { mg dm }^{-3}\end{array}$ \\
\hline 24 junho & $33,79 \mathrm{c}$ & $33,95 \mathrm{~b}$ & $57,76 \mathrm{ab}$ & $66,86 \mathrm{ab}$ & $3,34 \mathrm{c}$ \\
29 agosto & $38,35 \mathrm{bc}$ & $34,40 \mathrm{~b}$ & $47,93 \mathrm{~b}$ & $74,42 \mathrm{ab}$ & $6,65 \mathrm{a}$ \\
3 outubro & $47,09 \mathrm{~b}$ & $49,59 \mathrm{a}$ & $65,99 \mathrm{a}$ & $83,48 \mathrm{a}$ & $3,76 \mathrm{bc}$ \\
8 novembro & $63,17 \mathrm{a}$ & $61,25 \mathrm{a}$ & $55,18 \mathrm{ab}$ & $46,72 \mathrm{~b}$ & $4,73 \mathrm{~b}$ \\
13 dezembro & $46,65 \mathrm{~b}$ & $49,84 \mathrm{a}$ & $53,40 \mathrm{~b}$ & $65,05 \mathrm{ab}$ & $4,63 \mathrm{bc}$ \\
\hline
\end{tabular}

O zinco nas folhas foi alterado nas três últimas coletas, ocorrendo um aumento do nutriente devido à aplicação do adubo foliar que continha o zinco entre a segunda $e$ terceira coletas. O zinco passou de $33,79 \mathrm{mg} \mathrm{kg}^{-1}$ e $38,35 \mathrm{mg} \mathrm{kg}^{-1}$, na primeira e segunda coleta respectivamente para $47,09 \mathrm{mg} \mathrm{kg}^{-1}$ na terceira coleta, atingindo um pico de $63,17 \mathrm{mg} \mathrm{kg}^{-1}$ na quarta coleta, tendo o mesmo comportamento do cobre e do manganês.

Essa aplicação refletiu no nutriente nos galhos no qual o zinco passou de 33,95 $\mathrm{mg} \mathrm{kg}^{-1}$ na primeira coleta, para um máximo de $61,25 \mathrm{mg} \mathrm{kg}^{-1}$ na quarta coleta. Como esse nutriente tem uma mobilidade impedida quanto à redistribuição sua concentração na casca do tronco e raízes apresentaram essa tendência, de forma menos acentuada (Malavolta, 1980).

Quanto ao teor no solo, este teve alterações, no entanto elas não seguiram uma tendência com o passar do tempo, não tendo correlação com as concentrações de zinco na planta.

\subsection{Variedade Natal}

Para avaliação das concentrações de macro e micronutrientes na variedade Natal, os resultados foram agrupados de três diferentes modos. O primeiro foi o agrupamento por estágios de sintomatologia, onde as coletas foram divididas segundo cada estágio, a segunda maneira foi por época de coleta e, neste caso os estágios 
foram agrupados dentro de cada coleta, para que se pudesse avaliar o comportamento do nutriente dentro da planta com o passar do tempo, independente dos estágios de sintomatologia. Na terceira análise, foi avaliada a interação existente entre as épocas de coleta e os estágios de sintomas da morte súbita do citros, fazendo-se assim o desdobramento das duas primeiras.

\subsubsection{Nitrogênio}

Ao se analisar a concentração de nitrogênio dentro dos estágios de sintomatologia da morte súbita, pode-se observar diferenças do nutriente nos galhos (Tabela 35).

Tabela 35. Concentrações de nitrogênio em plantas de citros, variedade Natal, nos estágios da morte súbita do citros

\begin{tabular}{|c|c|c|c|c|}
\hline \multirow[t]{2}{*}{ Sintomas } & Folhas & Galhos & Casca do tronco & Raizes \\
\hline & -- & $-\cdots--$ & 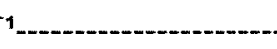 & -non \\
\hline 0 & 24,84 a & 9,59 a & 11,04 a & $10,87 a$ \\
\hline 1 & $21,67 a$ & $9,11 a b$ & 11,71 a & 9,34 a \\
\hline 2 & $20,72 a$ & $8,65 b$ & 11,58 a & 8,82 a \\
\hline 3 & 23,27 a & $8,67 a b$ & $12,09 \mathrm{a}$ & $8,49 a$ \\
\hline
\end{tabular}

À medida que os sintomas evoluíram, as concentrações de nitrogênio nos galhos diminuiram, mostrando assim uma diferenciação do nutriente na comparação de plantas assintomáticas e sintomáticas. O nitrogênio passou de $9,59 \mathrm{~g} \mathrm{~kg}^{-1}$ nas plantas assintomáticas para $8,65 \mathrm{~g} \mathrm{~kg}^{-1}$, no caso de plantas no estágio intermediário da doença. Segundo Chapman (1968), a concentração ideal de nitrogênio nos galhos é de $7,2 \mathrm{~g} \mathrm{~kg}^{-1}$, sendo assim, o nitrogênio nos galhos das plantas amostradas estão adequados, mesmo com a queda do nutriente devido ao avanço da doença.

Com a evolução da morte súbita do citros, o nitrogênio nas folhas permaneceu constante. No entanto foi detectada uma queda na concentração de nitrogênio em plantas cítricas afetadas por declínio (Coelho et al., 1983 e Tavares, 1987). No caso da clorose variegada do citros, a concentração de nitrogênio também caiu com a evolução da doença (Ricci et al., 2001).

Segundo Violante Netto et al. (1988) e Rodrigues et al. (1991), a concentração de nitrogênio adequada nas folhas de citros, geradas na primavera, com seis meses de 
idade, de ramos com fruto é de $23,00-27,00 \mathrm{~g} \mathrm{~kg}^{-1}$, que quando comparada com a média das coletas realizadas de $22,62 \mathrm{~g} \mathrm{~kg}^{-1}$ que foi um pouco abaixo da adequada e das plantas assintomáticas que apresentaram $24,84 \mathrm{~g} \mathrm{~kg}^{-1}$, resulta no primeiro caso em valores considerados inadequados e no segundo caso em valores adequados. Considerando-se a concentração adequada para a época da coleta do experimento de 20,00-25,00 $\mathrm{g} \mathrm{kg}^{-1}$ (Malavolta \& Prates, 1994), os valores de nitrogênio nas folhas continuam adequados.

Quando se verifica a casca do tronco e as raizes, pode-se dizer que ambas estavam deficientes quanto ao nitrogênio (Chapman, 1968), que deveriam ser de 16,40 $\mathrm{g} \mathrm{kg}^{-1}$ e $19,50 \mathrm{~g} \mathrm{~kg}^{-1}$ respectivamente.

Nas épocas de coletas pode-se verificar que os galhos, casca do tronco e as raizes tiveram alterações (Tabela 36 ).

Tabela 36. Concentrações de nitrogênio em plantas de citros, variedade Natal, nas épocas de coleta

\begin{tabular}{|c|c|c|c|c|}
\hline Coletas & Folhas & Galhos & Casca do tronco & Raizes \\
\hline & & & $\mathrm{kg}^{-1}$ & $\cdots$ \\
\hline 24 junho & 22,76 a & $10,46 a$ & 13,10 a & 11,19 a \\
\hline 29 agosto & 22,70 a & $8,87 a b$ & $11,10 \mathrm{bc}$ & $9,40 a b$ \\
\hline 3 outubro & 22,02 a & 8,78 b & $11,21 \mathrm{bc}$ & 9,81 a \\
\hline 8 novembro & 22,94 a & $9,90 \mathrm{ab}$ & $12,13 a b$ & $9,81 a b$ \\
\hline 13 dezembro & 22,70 a & $7,01 \mathrm{c}$ & $10,49 \mathrm{c}$ & $7,32 b$ \\
\hline
\end{tabular}

As concentrações de nitrogênio nos galhos e na casca do tronco foram afetadas a partir da primeira coleta, ocorrendo uma diminuição com o passar das coletas. Nos galhos, o nitrogênio passou de $10,46 \mathrm{~g} \mathrm{~kg}^{-1}$ na primeira coleta para $7,01 \mathrm{~g} \mathrm{~kg}^{-1}$ na última coleta, a mesma tendência ocorreu com a casca do tronco, na qual o referido nutriente passou de $13,10 \mathrm{~g} \mathrm{~kg}^{-1}$ na primeira coleta para $10,49 \mathrm{~g} \mathrm{~kg}^{-1}$ na quinta coleta. Já nas raizes, essa diminuição nutricional não foi tão acentuada e regular, sendo que apenas na última coleta a queda do nutriente foi mais expressiva, diferenciando-se das demais, passando de $11,19 \mathrm{~g} \mathrm{~kg}^{-1}$ na primeira coleta para $7,32 \mathrm{~g} \mathrm{~kg}^{-1}$ na última coleta. Essa diminuição pode ser devida à pequena permanência desse nutriente nessas partes da planta, por ser um nutriente extremamente móvel na planta (Marschner, 1997 e Violante Netto et al., 1988) e estar sempre migrando para as partes mais novas da 
planta. Sendo que, com o início do florescimento ocorre uma redistribuição do mesmo na planta (Malavolta \& Violante Netto, 1989).

\subsubsection{Fósforo}

Ao se analisar a concentração de fósforo dentro dos estágios de sintomatologia da morte súbita do citros, pode-se observar diferenças no nutriente nos galhos (Tabela 37).

Tabela 37. Concentrações de fósforo em plantas de citros, variedade Natal, e do solo nos estágios da morte súbita do citros

\begin{tabular}{cccccccc}
\hline Sintomas & Folhas & Galhos & $\begin{array}{c}\text { Casca do tronco } \\
\text { Raizes }\end{array}$ & $\begin{array}{c}\text { Solo } \\
\mathrm{mg} \mathrm{dm}^{-3}\end{array}$ \\
\hline 0 & $1,41 \mathrm{a}$ & $0,68 \mathrm{a}$ & $0,59 \mathrm{a}$ & $0,83 \mathrm{a}$ & $19,53 \mathrm{a}$ \\
1 & $1,36 \mathrm{a}$ & $0,61 \mathrm{~b}$ & $0,63 \mathrm{a}$ & $0,77 \mathrm{a}$ & $18,92 \mathrm{a}$ \\
2 & $1,36 \mathrm{a}$ & $0,64 \mathrm{ab}$ & $0,61 \mathrm{a}$ & $0,72 \mathrm{a}$ & $18,34 \mathrm{a}$ \\
3 & $1,45 \mathrm{a}$ & $0,61 \mathrm{~b}$ & $0,62 \mathrm{a}$ & $0,85 \mathrm{a}$ & $20,55 \mathrm{a}$ \\
\hline
\end{tabular}

Com o aparecimento dos sintomas, as concentrações de fósforo nos galhos diminuíram, mostrando assim uma diferenciação do nutriente na comparação de plantas assintomáticas e sintomáticas. $O$ fósforo passou de $0,68 \mathrm{~g} \mathrm{~kg}^{-1}$, nas plantas assintomáticas para $0,61 \mathrm{~g} \mathrm{~kg}^{-1}$ nas plantas no estágio terminal. Segundo Chapman (1968), a concentração de fósforo ideal nos galhos é de $2,2 \mathrm{~g} \mathrm{~kg}^{-1}$, sendo que o nutriente nas plantas assintomáticas já estava abaixo do ideal e com a evolução da doença, diminuiu ainda mais. Quanto ao fósforo na casca do tronco e nas raízes, eles foram considerados deficientes (Chapman, 1968), sendo que os valores adequados seriam de $2,4 \mathrm{~g} \mathrm{~kg}^{-1}$ e $2,5 \mathrm{~g} \mathrm{~kg}^{-1}$ respectivamente.

Quanto ao solo, pode-se dizer que não ocorreram diferenças do nutriente com a evolução da doença, não influenciando assim na queda do nutriente que ocorreu nos galhos, sendo este teor considerado adequado (Raij et al., 1996).

Houve queda na concentração de fósforo nas folhas de citrus cv. Valência com a evolução do declínio, em experimentos realizados no Brasil (Tavares, 1987 e Coelho et al., 1983), o mesmo ocorreu com a morte súbita na variedade Pêra Rio, onde o referido nutriente diminuiu quando se compararam plantas assintomáticas com plantas sintomáticas, no entanto na variedade Natal, a concentração permaneceu constante. 
Segundo Violante Netto et al. (1988) e Rodrigues et al. (1991), a concentração de fósforo adequada nas folhas de citros geradas na primavera, com seis meses de idade, de ramos com fruto é de 1,20-1,60 $\mathrm{g} \mathrm{kg}^{-1}$, que quando comparada com a média das coletas realizadas de $1,39 \mathrm{~g} \mathrm{~kg}^{-1} \mathrm{e}$ das plantas assintomáticas que apresentaram $1,41 \mathrm{~g} \mathrm{~kg}^{-1}$, resulta nos dois casos em valores considerados adequados. Considerandose a concentração adequada para a época coletada no experimento de $1,20-1,50 \mathrm{~g} \mathrm{~kg}^{-1}$ (Malavolta \& Prates, 1994), os valores encontrados também foram considerados ideais.

Quanto às épocas de coletas pode-se verificar que toda a planta (folhas, galhos, casca do tronco e raízes), tiveram alterações nutricionais, com o passar do tempo (Tabela 38).

Tabela 38. Concentrações de fósforo em plantas de citros, variedade Natal, e do solo nas épocas de coleta

\begin{tabular}{ccccccc}
\hline Coletas & Folhas & Galhos & $\begin{array}{c}\text { Casca do tronco } \\
\text { 24 juizes }\end{array}$ & $\begin{array}{c}\text { Solo } \\
\mathrm{mg} \mathrm{dm}^{-3}\end{array}$ \\
\hline 29 agosto & $1,48 \mathrm{~b}$ & $0,61 \mathrm{~b}$ & $0,51 \mathrm{~b}$ & $0,92 \mathrm{~b}$ & $23,12 \mathrm{a}$ \\
3 outubro & $0,87 \mathrm{c}$ & $0,41 \mathrm{c}$ & $0,36 \mathrm{c}$ & $0,60 \mathrm{c}$ & $25,05 \mathrm{a}$ \\
8 novembro & $0,99 \mathrm{c}$ & $0,42 \mathrm{c}$ & $0,38 \mathrm{c}$ & $0,58 \mathrm{c}$ & $14,76 \mathrm{a}$ \\
13 dezembro & $1,40 \mathrm{~b}$ & $0,47 \mathrm{c}$ & $0,46 \mathrm{bc}$ & $0,48 \mathrm{c}$ & $15,71 \mathrm{a}$ \\
\hline
\end{tabular}

O fósforo na última coleta foi alterado com relação às demais coletas, ocorrendo um aumento. Esse aumento no nutriente na última coleta não foi devido ao teor do nutriente no solo, pois esse não foi alterado com o passar das coletas, podendo ter sido devido ao aumento da temperatura (Havlin et al., 1999) que aumentou o metabolismo da planta e a demanda pelo nutriente, devido à frutificação (Castro et al., 2001).

Segundo Kampfer e Uexkull (1966), as concentrações adequadas do nutriente nessas partes da planta são: $1,8 \mathrm{~g} \mathrm{~kg}^{-1}$ nas folhas; $1,7 \mathrm{~g} \mathrm{~kg}^{-1}$ nos galhos e $2,1 \mathrm{~g} \mathrm{~kg}^{-1}$ no tronco, podendo-se assim, afirmar que somente as folhas na última coleta estavam com os valores adequados, na casca do tronco e nos galhos estavam menores do que o adequado. Pode-se notar que a mesma tendência ocorreu com a variedade Pêra Rio.

Quanto à interação entre época de amostragem e estágios de sintomatologia da doença, esta ocorreu somente nos galhos (Tabela 39). 
Tabela 39. Concentrações de fósforo na interação entre épocas de coleta e estágios de manifestação de sintomas na planta, nos galhos de plantas da variedade Natal

\begin{tabular}{crrrrr}
\hline & 0 & 1 & 2 & 3 \\
\hline 24 junho & $0,79 \mathrm{Ba}$ & $0,62 \mathrm{Ba}$ & $0,6 \mathrm{Ba}$ & $0,43 \mathrm{Ba}$ \\
29 agosto & $0,44 \mathrm{Ba}$ & $0,35 \mathrm{Ba}$ & $0,41 \mathrm{Ba}$ & $0,46 \mathrm{Ba}$ \\
3 outubro & $0,43 \mathrm{Ba}$ & $0,38 \mathrm{Ba}$ & $0,44 \mathrm{Ba}$ & $0,42 \mathrm{Ba}$ \\
8 novembro & $0,45 \mathrm{Ba}$ & $0,43 \mathrm{Ba}$ & $0,47 \mathrm{Ba}$ & $0,53 \mathrm{Ba}$ \\
13 dezembro & $1,3 \mathrm{Aa}$ & $1,27 \mathrm{Aa}$ & $1,25 \mathrm{Aa}$ & $1,2 \mathrm{Aa}$ \\
\hline
\end{tabular}

Médias seguidas pela mesma letra, minúscula na linha e maiúscula na coluna, não diferem entre si pelo teste de Tukey a $5 \%$.

Quanto às épocas de amostragem, observou-se que houve um aumento do nutriente nos galhos na quinta coleta, em todos os estágios da doença. Quanto à evolução da sintomatologia, o fósforo não se alterou em nenhuma coleta.

\subsubsection{Potássio}

Ao se analisar a concentração de potássio dentro dos estágios de sintomatologia da morte súbita do citros, pode-se observar diferenças no nutriente das folhas, nos galhos e na casca do tronco. Diferentemente da variedade Pêra Rio que teve alterações do nutriente somente nas folhas e galhos (Tabela 40).

Tabela 40. Concentrações de potássio em plantas de citros, variedade Natal, e do solo nos estágios da morte súbita do citros

\begin{tabular}{cccccccc}
\hline Sintomas & \multicolumn{2}{c}{ Folhas } & Galhos & $\begin{array}{c}\text { Casca do tronco } \\
\text { Raizes }\end{array}$ & \multicolumn{2}{c}{$\begin{array}{c}\text { Solo } \\
\mathrm{mmol}_{\mathrm{c}} \mathrm{dm}^{-3}\end{array}$} \\
\hline 0 & $10,16 \mathrm{a}$ & $4,08 \mathrm{a}$ & $3,34 \mathrm{a}$ & $6,94 \mathrm{a}$ & $0,79 \mathrm{~b}$ \\
1 & $6,54 \mathrm{~b}$ & $2,56 \mathrm{~b}$ & $2,25 \mathrm{~b}$ & $6,02 \mathrm{a}$ & $0,69 \mathrm{~b}$ \\
2 & $8,01 \mathrm{ab}$ & $3,00 \mathrm{~b}$ & $2,91 \mathrm{ab}$ & $5,25 \mathrm{a}$ & $0,90 \mathrm{~b}$ \\
3 & $6,17 \mathrm{~b}$ & $2,59 \mathrm{~b}$ & $2,72 \mathrm{ab}$ & $4,64 \mathrm{a}$ & $2,00 \mathrm{a}$ \\
\hline
\end{tabular}

À medida que os sintomas evoluíram, o potássio nas folhas diminuiu, mostrando assim, uma diferenciação do nutriente na comparação entre plantas assintomáticas e sintomáticas. O nutriente passou de $10,16 \mathrm{~g} \mathrm{~kg}^{-1}$ nas plantas assintomáticas para $6,54 \mathrm{~g} \mathrm{~kg}^{-1}$ nas plantas no primeiro estágio de sintomatologia da doença, com posterior aumento para $8,01 \mathrm{~g} \mathrm{~kg}^{-1}$ no estágio intermediário de sintomatologia, e nova queda no estágio terminal da doença de $6,17 \mathrm{~g} \mathrm{~kg}^{-1}$. Como no 
caso da morte súbita, também ocorre queda na concentração de potássio nas folhas das plantas afetadas por declínio (Wutscher \& Hardesty, 1979 e Coelho et al., 1983) e quando se analisou plantas com clorose variegada do citros o comportamento do nutriente foi o mesmo (Ricci et al., 2001).

Segundo Violante Netto et al. (1988) e Rodrigues et al. (1991), a concentração de potássio adequada nas folhas de citros geradas na primavera, com seis meses de idade, de ramos com fruto é de $12,00-17,00 \mathrm{~g} \mathrm{~kg}^{-1}$, que quando comparada com a média das coletas realizadas de $7,72 \mathrm{~g} \mathrm{~kg}^{-1} \mathrm{e}$ das plantas assintomáticas que apresentaram $10,16 \mathrm{~g} \mathrm{~kg}^{-1}$, resulta em ambos os casos em valores considerados abaixo do ideal. Considerando-se o valor adequado para a época coletada no experimento de $10,00-12,00 \mathrm{~g} \mathrm{~kg}^{-1}$ (Malavolta \& Prates, 1994), apenas as plantas assintomáticas se encontravam adequadas.

Nos galhos, essa diminuição também ocorreu, sendo que o nutriente passou de $4,08 \mathrm{~g} \mathrm{~kg}^{-1}$ nas plantas assintomáticas para $2,59 \mathrm{~g} \mathrm{~kg}^{-1}$ nas plantas que apresentavam o último grau de sintomatologia. Segundo Chapman (1968), a concentração adequada do nutriente nos galhos é de $2,40 \mathrm{~g} \mathrm{~kg}^{-1}$, sendo assim, a planta estava com o potássio adequado, mesmo com a queda do nutriente, com a evolução dos sintomas. Quanto ao potássio nas raízes, este se encontrou adequado, pois segundo Chapman (1968), a concentração adequada é de $5,90 \mathrm{~g} \mathrm{~kg}^{-1}$.

$\mathrm{Na}$ casca do tronco, essa diminuição do potássio também ocorreu, diferenciando as plantas assintomáticas com $3,34 \mathrm{~g} \mathrm{~kg}^{-1}$, dos demais estágios da doença, como $2,25 \mathrm{~g} \mathrm{~kg}^{-1}$, que corresponde à fase inicial de manifestação dos sintomas. Segundo Chapman (1968), o valor adequado do nutriente na casca do tronco é de $6,60 \mathrm{~g} \mathrm{~kg}^{-1}$, sendo assim, a planta mostrou concentração deficiente.

Quanto ao solo, este não influenciou o potássio na planta, pois somente no estágio mais avançado da doença é que ocorreu um acúmulo do nutriente, sendo provavelmente devido a uma menor absorção do mesmo, com a diminuição do sistema radicular e da massa seca da planta (Pivetta, 2003; Fundecitrus, 2002a). O potássio se encontrava deficiente no solo e, apenas no ultimo estágio de sintomatologia foi que o teor se encontrou adequado (Raij et al., 1996).

Quanto às épocas de coleta percebe-se novamente, que o potássio foi afetado nas folhas, galhos e casca do tronco, como ocorreu com os estágios de sintomatologia (Tabela 41). 
Tabela 41. Concentrações de potássio em plantas de citros, variedade Natal, e do solo nas épocas de coleta

\begin{tabular}{|c|c|c|c|c|c|}
\hline Coletas & Folhas & Galhos & $\begin{array}{l}\text { Casca do tronco } \\
\mathrm{kg}^{-1}\end{array}$ & Raízes & $\begin{array}{l}\text { Solo } \\
\mathrm{mmol}_{\mathrm{c}} \mathrm{dm}^{-3}\end{array}$ \\
\hline 24 junho & $8,08 \mathrm{~b}$ & $2,95 \mathrm{~b}$ & 2,44 bc & $6,24 a$ & 1,48 a \\
\hline 29 agosto & $6,57 \mathrm{~b}$ & $2,93 \mathrm{~b}$ & $2,18 \mathrm{c}$ & 4,89 a & $1,11 a b$ \\
\hline 3 outubro & $5,77 \mathrm{~b}$ & $2,50 \mathrm{~b}$ & $2,14 \mathrm{c}$ & 6,28 a & $1,12 a b$ \\
\hline 8 novembro & $10,97 a$ & 4,22 a & $4,10 a$ & $5,26 a$ & $0,73 \mathrm{~b}$ \\
\hline 13 dezembro & $7,22 \mathrm{~b}$ & $2,68 \quad b$ & $3,16 \mathrm{ab}$ & 4,73 a & $1,03 \mathrm{ab}$ \\
\hline
\end{tabular}

Ocorreu aumento do potássio na parte aérea, galhos, folhas e casca do tronco na quarta coleta, provavelmente devido ao aumento das precipitações e da temperatura que aumentaram o metabolismo da planta (Havlin et al., 1999). Nota-se que esse comportamento do potássio na parte aérea da planta não seguiu a mesma tendência no solo, que teve seu teor diminuido com o passar do tempo.

\subsubsection{Cálcio}

Ao se analisar a concentração de cálcio dentro dos estágios de sintomatologia da morte súbita do citros pode-se notar diferenças do nutriente apenas nas folhas, que diferiu da variedade Pêra Rio que teve diferenças nas raízes, com a intensificação da doença (Tabela 42).

Tabela 42. Concentrações de cálcio em plantas de citros, variedade Natal, e do solo nos estágios da morte súbita do citros

\begin{tabular}{|c|c|c|c|c|c|}
\hline Sintomas & Folhas & Galhos & Casca do tronco & Raizes & $\begin{array}{c}\text { Solo } \\
\mathrm{mmol}_{\mathrm{c}} \mathrm{dm}^{-3}\end{array}$ \\
\hline 0 & $23,62 b$ & 15,50 a & 32,00 a & 14,35 a & 37,27 a \\
\hline 1 & 27,85 a & $15,70 a$ & 33,09 a & $15,21 \mathrm{a}$ & 25,97 a \\
\hline 2 & $23,88 b$ & 14,28 a & 33,99 a & 13,69 a & 37,55 a \\
\hline 3 & $26,06 a b$ & 15,77 a & 33,65 a & 13,14 a & 39,35 a \\
\hline
\end{tabular}

À medida que os sintomas evoluíram na parte aérea, o cálcio das folhas sofreu uma alteração irregular não acompanhando a intensificação da manifestação da doença. $O$ cálcio teve um aumento inicial, passando de $23,62 \mathrm{~g} \mathrm{~kg}^{-1}$ nas plantas assintomáticas para $27,85 \mathrm{~g} \mathrm{~kg}^{-1}$ nas plantas no primeiro estágio de sintomatologia da doença, no entanto houve uma queda para, $23,88 \mathrm{~g} \mathrm{~kg}^{-1}$ no estágio intermediário $\mathrm{e}$ posterior aumento na fase final para $26,06 \mathrm{~g} \mathrm{~kg}^{-1}$. Com esses resultados fica 
complicado chegar-se a qualquer conclusão sobre a influência do cálcio, isto também ocorreu com a variedade Pêra Rio. No entanto com o avanço do declínio do citros pôde ser notado um aumento do nutriente (Coelho et al., 1983), no caso da clorose variegada do citros ocorreu uma situação inversa, isto é, a concentração do nutriente caiu com o avanço da doença (Ricci et al., 2001).

O solo não influenciou o comportamento do cálcio na folha, pois o nutriente não variou no solo, com a intensificação da doença, sendo que o teor considerado adequado é de $7 \mathrm{mmol}_{\mathrm{c}} \mathrm{dm}^{-3}$ (Raij et al., 1996).

Segundo Violante Netto et al. (1988) e Rodrigues et al. (1991), a concentração de cálcio adequada nas folhas de citros geradas na primavera, com seis meses de idade, de ramos com fruto é de $30-45 \mathrm{~g} \mathrm{~kg}^{-1}$, que quando comparada com a média das coletas realizadas de $25,35 \mathrm{~g} \mathrm{~kg}^{-1} \mathrm{e}$ das plantas assintomáticas que apresentaram 23,62 $\mathrm{g} \mathrm{kg}^{-1}$, resulta nos dois casos em valores considerados deficientes. Mesmo consierando-se ao valor adequado para a época da coleta no experimento, de 30,00$45,00 \mathrm{~g} \mathrm{~kg}^{-1}$ (Malavolta \& Prates, 1994), os valores continuaram deficientes.

Quanto aos valores de cálcio nos galhos, estes foram considerados adequados, no entanto, deficientes na casca do tronco e nas raizes (Chapman, 1968) que deveriam ser de $44,00 \mathrm{~g} \mathrm{~kg}^{-1}$ e $44,60 \mathrm{~g} \mathrm{~kg}^{-1}$ respectivamente.

Nas épocas de coletas pode-se notar que o cálcio foi afetado em todas as partes da planta (folhas, galhos, casca do tronco e raízes) (Tabela 43).

Tabela 43. Concentrações de cálcio em plantas de citros, variedade Natal, e do solo nas épocas de coleta

\begin{tabular}{cccccccc}
\hline Coletas & Folhas & Galhos & $\begin{array}{c}\text { Casca do tronco } \\
\text { Raizes }\end{array}$ & $\begin{array}{c}\text { Solo } \\
\mathrm{mmol}_{\mathrm{cm}} \mathrm{dm}^{-3}\end{array}$ \\
\hline 24 junho & $30,93 \mathrm{a}$ & $13,32 \mathrm{~b}$ & $36,50 \mathrm{~b}$ & $13,90 \mathrm{ab}$ & $46,02 \mathrm{a}$ \\
29 agosto & $28,81 \mathrm{a}$ & $15,42 \mathrm{ab}$ & $45,17 \mathrm{a}$ & $12,26 \mathrm{~b}$ & $33,44 \mathrm{~b}$ \\
3 outubro & $18,42 \mathrm{c}$ & $13,69 \mathrm{~b}$ & $18,82 \mathrm{c}$ & $12,83 \mathrm{~b}$ & $30,40 \mathrm{~b}$ \\
8 novembro & $22,08 \mathrm{bc}$ & $18,12 \mathrm{a}$ & $32,75 \mathrm{~b}$ & $18,61 \mathrm{ab}$ & $29,40 \mathrm{~b}$ \\
13 dezembro & $26,53 \mathrm{ab}$ & $16,00 \mathrm{ab}$ & $32,66 \mathrm{~b}$ & $21,07 \mathrm{a}$ & $35,92 \mathrm{ab}$ \\
\hline
\end{tabular}

Os valores de cálcio nas folhas das duas primeiras coletas foram estáveis, no entanto ocorreu uma queda após essa época, com posterior aumento na última coleta. Sendo que passou de $30,93 \mathrm{~g} \mathrm{~kg}^{-1}$ na primeira coleta para $18,42 \mathrm{~g} \mathrm{~kg}^{-1}$ na terceira coleta, voltando a $26,63 \mathrm{~g} \mathrm{~kg}^{-1}$ na ultima coleta. A concentração ideal do nutriente nas 
folhas segundo Rodrigues (1991) é de $30 \mathrm{~g} \mathrm{~kg}^{-1}$, podendo-se dizer, que somente na primeira coleta o cálcio estava adequado.

Nas raízes e nos galhos, o cálcio teve um aumento com o passar das coletas. Nas raízes passou de $13,90 \mathrm{~g} \mathrm{~kg}^{-1}$ na primeira coleta para $21,07 \mathrm{~g} \mathrm{~kg}^{-1}$ na ultima coleta, já nos galhos esse aumentou não foi tão acentuado, passando de $13,32 \mathrm{~g} \mathrm{~kg}^{-1} \mathrm{na}$ primeira coleta para $16,00 \mathrm{~g} \mathrm{~kg}^{-1}$ na ultima coleta, tendo um pico de $18,12 \mathrm{~g} \mathrm{~kg}^{-1} \mathrm{na}$ quarta coleta. Na casca do tronco as alterações do nutriente foram irregulares com o passar do tempo.

Quanto ao solo, ocorreu uma queda do referido nutriente a partir da primeira coleta, podendo assim inferir-se que o mesmo pode ter influenciado na concentração foliar, que teve um comportamento semelhante ao do solo.

\subsubsection{Magnésio}

Ao se analisar a concentração de magnésio dentro dos estágios de sintomatologia da morte súbita do citros, pode-se perceber que ocorreu diferença apenas na casca do tronco, diferentemente da variedade Pêra Rio que não teve alteração do nutriente com a evolução da doença (Tabela 44).

Tabela 44. Concentrações de magnésio em plantas de citros, variedade Natal, e do solo nos estágios da morte súbita do citros

\begin{tabular}{cccccccr}
\hline Sintomas & Folhas & Galhos & $\begin{array}{c}\text { Casca do tronco } \\
\text { Raizes }\end{array}$ & $\begin{array}{r}\text { solo } \\
\mathrm{mmol}_{\mathrm{c}} \mathrm{dm}^{-3}\end{array}$ \\
\hline 0 & $2,80 \mathrm{a}$ & $0,95 \mathrm{a}$ & $1,20 \mathrm{~b}$ & $0,93 \mathrm{a}$ & $11,70 \mathrm{a}$ \\
1 & $3,30 \mathrm{a}$ & $1,00 \mathrm{a}$ & $1,30 \mathrm{ab}$ & $0,92 \mathrm{a}$ & $6,47 \mathrm{~b}$ \\
2 & $2,86 \mathrm{a}$ & $0,95 \mathrm{a}$ & $1,43 \mathrm{ab}$ & $0,90 \mathrm{a}$ & $9,45 \mathrm{ab}$ \\
3 & $3,25 \mathrm{a}$ & $0,84 \mathrm{a}$ & $1,58 \mathrm{a}$ & $0,71 \mathrm{a}$ & $10,40 \mathrm{ab}$ \\
\hline
\end{tabular}

A concentração de magnésio na casca do tronco, aumentou à medida que os sintomas se intensificaram. Os valores passaram de $1,20 \mathrm{~g} \mathrm{~kg}^{-1}$ nas plantas assintomáticas para $1,30 \mathrm{~g} \mathrm{~kg}^{-1} \mathrm{em}$ plantas no primeiro estágio de sintomatologia, chegando a $1,58 \mathrm{~g} \mathrm{~kg}^{-1}$ nas plantas mortas.

Esses resultados mostram que pode estar ocorrendo um acúmulo do nutriente no floema, não sendo transportado para as raizes, devido ao entupimento do mesmo com a doença (Pivetta, 2003; Fundecitrus, 2002a). Segundo Chapman (1968), a 
concentração adequada do nutriente na casca do tronco é de $3,50 \mathrm{~g} \mathrm{~kg}^{-1}$, sendo assim este nutriente estava sempre deficiente nesta parte da planta.

Quanto ao solo, ele não teve influência sobre o comportamento do nutriente na casca do tronco, pois o teor do nutriente teve alterações irregulares com o desenvolvimento da doença, sendo que esses teores foram considerados adequados no solo (Raij et al., 1996).

No caso da morte súbita não ocorreu alteração na concentração de magnésio das folhas de plantas afetadas, como no caso da variedade Pêra Rio. Ao estudar a concentração nutricional de plantas afetadas com o declínio do citros, Giroto (1990) notou a queda do magnésio foliar com o avanço da doença, no caso da clorose variegada do citros também foi observada uma queda nesse nutriente com o avanço da doença (Ricci et al., 2001).

Segundo Violante Netto et al. (1988) e Rodrigues et al. (1991), a concentração de magnésio adequada nas folhas de citros geradas na primavera, com seis meses de idade, de ramos com fruto é de $3,00-4,90 \mathrm{~g} \mathrm{~kg}^{-1}$, quando comparada com a média das coletas de $3,05 \mathrm{~g} \mathrm{~kg}^{-1} \mathrm{e}$ das plantas assintomáticas que apresentaram $2,80 \mathrm{~g} \mathrm{~kg}^{-1}$ resulta nos dois casos em valores considerados adequados.

Nos galhos, o magnésio foi adequado, no entanto nas raizes o valor estava deficiente, sendo que segundo Chapman (1968) a concentração adequada deveria ser de $2,20 \mathrm{~g} \mathrm{~kg}^{-1}$.

Quanto às épocas de coletas, pode-se notar que os valores de magnésio foram afetados nas folhas, galhos e raizes, como ocorreu com a variedade Pêra Rio (Tabela 45).

Tabela 45. Concentrações de magnésio em plantas de citros, variedade Natal, e do solo nas épocas de coleta

\begin{tabular}{cllllll}
\hline Coletas & Folhas & Galhos & $\begin{array}{c}\text { Casca do tronco } \\
\text { Raizes }\end{array}$ & $\begin{array}{r}\text { Solo } \\
\mathrm{mmol}_{\mathrm{c}} \mathrm{dm}^{-3}\end{array}$ \\
\hline 24 junho & $3,36 \mathrm{a}$ & $0,90 \mathrm{~b}$ & $1,47 \mathrm{a}$ & $1,07 \mathrm{a}$ & $12,88 \mathrm{a}$ \\
29 agosto & $3,07 \mathrm{ab}$ & $1,23 \mathrm{a}$ & $1,44 \mathrm{a}$ & $0,87 \mathrm{ab}$ & $9,60 \mathrm{ab}$ \\
3 outubro & $2,99 \mathrm{ab}$ & $0,74 \mathrm{~b}$ & $1,26 \mathrm{a}$ & $0,79 \mathrm{~b}$ & $8,79 \mathrm{ab}$ \\
8 novembro & $2,75 \mathrm{~b}$ & $0,93 \mathrm{~b}$ & $1,36 \mathrm{a}$ & $0,80 \mathrm{~b}$ & $8,04 \mathrm{~b}$ \\
13 dezembro & $3,08 \mathrm{ab}$ & $0,87 \mathrm{~b}$ & $1,34 \mathrm{a}$ & $0,94 \mathrm{~b}$ & $8,21 \mathrm{~b}$ \\
\hline
\end{tabular}

O magnésio nas folhas sofreu uma queda, quando se compara a primeira época com as demais, passando de $3,36 \mathrm{~g} \mathrm{~kg}^{-1}$ na primeira coleta para $2,75 \mathrm{~g} \mathrm{~kg}^{-1} \mathrm{na}$ 
quarta coleta, por exemplo. Nos galhos também ocorreram diferenças nutricionais entre uma coleta e outra, no entanto não seguiu nenhuma tendência de queda ou aumento do nutriente com o passar do tempo. Já nas raizes houve uma tendência de queda com o decorrer do tempo, passando de $1,07 \mathrm{~g} \mathrm{~kg}^{-1}$ para $0,80 \mathrm{~g} \mathrm{~kg}^{-1}$ na quarta coleta.

O teor de magnésio do solo, nesse caso, pode ter influenciado as quedas de magnésio, tanto nas folhas quanto nas raizes. Sendo que o magnésio passou de 12,88 $\mathrm{mmol}_{\mathrm{c}} \mathrm{dm}^{-3}$ na primeira coleta, para $8,04 \mathrm{mmol}_{\mathrm{c}} \mathrm{dm}^{-3}$ na quarta coleta, apesar da queda, estes valores foram considerados adequados (Raij et al., 1996).

Quanto à interação entre época de amostragem e estágios de sintomatologia da doença, esta foi observada nas raizes (Tabela 46).

Tabela 46. Concentrações de magnésio na interação entre épocas de coleta e estágios de manifestação de sintomas na planta, nas raízes de plantas da variedade Natal

\begin{tabular}{cccccc}
\hline & 0 & 1 & 2 & 3 \\
\hline 24 junho & $0,98 \mathrm{Aa}$ & $1,03 \mathrm{Aa}$ & $1,13 \mathrm{Aa}$ & $1,15 \mathrm{Aa}$ \\
29 agosto & $1,08 \mathrm{Aa}$ & $1,00 \mathrm{Aa}$ & $0,95 \mathrm{Aa}$ & $0,45 \mathrm{Ba}$ \\
3 outubro & $0,98 \mathrm{Aa}$ & $0,70 \mathrm{Aa}$ & $0,75 \mathrm{Aa}$ & $0,73 \mathrm{ABa}$ \\
8 novembro & $1,00 \mathrm{Aa}$ & $0,80 \mathrm{Aa}$ & $1,00 \mathrm{Aa}$ & $0,43 \mathrm{Ba}$ \\
13 dezembro & $0,65 \mathrm{Aa}$ & $1,03 \mathrm{Aa}$ & $0,70 \mathrm{Aa}$ & $0,80 \mathrm{ABa}$ \\
\hline
\end{tabular}

Médias seguidas pela mesma letra, minúscula na linha e maiúscula na coluna, não diferem entre si pelo teste de Tukey a $5 \%$.

Nota-se que, apenas no último estágio de sintomatologia ocorreu diferença na concentração de magnésio com o decorrer das coletas, podendo-se assim inferir, que houve uma queda do nutriente depois da primeira coleta e a partir daí ocorreram oscilações, não seguindo assim uma tendência com o passar do tempo.

\subsubsection{Enxofre}

Ao se analisar a concentração de enxofre dentro dos estágios de sintomatologia da morte súbita do citros, pode-se notar diferenças do nutriente nas raízes. Sendo que na variedade Pêra Rio essa diferenças ocorreram somente nas folhas (Tabela 47). 
Tabela 47. Concentrações de enxofre em plantas de citros, variedade Natal, e do solo estágios da morte súbita do citros

\begin{tabular}{cccccccc}
\hline Sintomas & Folhas & Galhos & $\begin{array}{c}\text { Casca do tronco } \\
\text { Raizes }\end{array}$ & $\begin{array}{c}\text { solo } \\
\text { mg dm }^{-3}\end{array}$ \\
\hline 0 & 2,71 a & 0,84 a & 0,84 a & 1,24 a & 19,57 ab \\
1 & 2,72 a & 1,01 a & 0,96 a & 1,00 ab & $24,88 \mathrm{a}$ \\
2 & 2,79 a & 0,80 a & 0,84 a & 0,89 ab & $17,96 \mathrm{~b}$ \\
3 & 2,52 a & $0,82 \mathrm{a}$ & $0,91 \mathrm{a}$ & $0,91 \mathrm{~b}$ & $19,94 \mathrm{ab}$ \\
\hline
\end{tabular}

À medida que os sintomas evoluíram, o enxofre diminuiu nas raizes desde as plantas assintomáticas até os últimos estágios de sintomatologia da morte súbita do citros. O nutriente passou de $1,24 \mathrm{~g} \mathrm{~kg}^{-1}$ nas plantas assintomáticas para $1,00 \mathrm{~g} \mathrm{~kg}^{-1}$ nas plantas que estavam no primeiro estágio de sintomatologia da doença, chegando a $0,91 \mathrm{~g} \mathrm{~kg}^{-1}$ nas raízes das plantas no último estágio da doença, mostrando que o avanço da doença prejudica a absorção do nutriente, pois além de diminuir a quantidade do nutriente pela redução do volume de sistema radicular, a sua concentração também é prejudicada com o avanço da doença. Segundo Chapman (1994), o valor adequado de enxofre nas raízes é de $1,40 \mathrm{~g} \mathrm{~kg}^{-1}$, sendo assim, as plantas coletadas estavam sempre deficientes.

Essa diminuição do enxofre no sistema radicular pode ser explicada, em parte, pelas oscilações do mesmo no solo, no entanto, não se pode esquecer que a diminuição do sistema radicular, principalmente das radicelas, influenciou nessa queda (Pivetta, 2003 e Fundecitrus, 2002a). O teor do nutriente no solo estava adequado, apesar de todas as oscilações que ocorrendo com a evolução da doença (Raij et al., 1996)

Na variedade Pêra Rio ocorreu diminuição da concentração de enxofre nas folhas de plantas afetadas, até o ultimo grau de sintomatologia, no entanto para a variedade Natal não ocorreu alteração alguma de enxofre nas folhas. No caso do declínio dos citros houve um aumento da concentração de enxofre com o decorrer da doença (Wutscher \& McDonald, 1986).

Segundo Violante Netto et al. (1988) e Rodrigues et al. (1991), a concentração de enxofre adequada nas folhas de citros geradas na primavera, com seis meses de idade, de ramos com fruto é de 2,00-3,90 $\mathrm{g} \mathrm{kg}^{-1}$, que quando comparada com a média das coletas realizadas de $2,62 \mathrm{~g} \mathrm{~kg}^{-1} \mathrm{e}$ das plantas assintomáticas que apresentaram $2,71 \mathrm{~g} \mathrm{~kg}^{-1}$, resulta nos dois casos em valores considerados adequados. Mesmo 
considerando-se a concentração adequada para a época coletada no experimento de 2,00-2,50 $\mathrm{g} \mathrm{kg}^{-1}$ (Malavolta \& Prates, 1994), o nutriente continuou adequado.

O enxofre nos galhos e na casca do tronco foi considerado deficiente, pois segundo Chapman (1968), as concentrações adequadas são de $1,20 \mathrm{~g} \mathrm{~kg}^{-1}$ e $1,80 \mathrm{~g}$ $\mathrm{kg}^{-1}$ respectivamente.

Quanto às épocas de coletas, o enxofre foi afetado em todas as partes da planta (folhas, galhos, casca do tronco e raizes) (Tabela 48).

Tabela 48. Concentrações de enxofre em plantas de citros, variedade Natal, e do solo nas épocas de coleta

\begin{tabular}{cccccccc}
\hline Coletas & Folhas & Galhos & $\begin{array}{c}\text { Casca do tronco } \\
\text { Raizes }\end{array}$ & $\begin{array}{c}\text { Solo } \\
\mathrm{mg} \mathrm{dm}^{-3}\end{array}$ \\
\hline 24 junho & $2,87 \mathrm{a}$ & $0,92 \mathrm{ab}$ & $0,89 \mathrm{~b}$ & $1,06 \mathrm{~b}$ & $18,45 \mathrm{c}$ \\
29 agosto & $2,86 \mathrm{a}$ & $0,74 \mathrm{~b}$ & $0,69 \mathrm{~b}$ & $0,81 \mathrm{bc}$ & $19,05 \mathrm{bc}$ \\
3 outubro & $2,79 \mathrm{a}$ & $0,76 \mathrm{~b}$ & $0,79 \mathrm{~b}$ & $1,04 \mathrm{~b}$ & $25,18 \mathrm{a}$ \\
8 novembro & $1,89 \mathrm{~b}$ & $0,59 \mathrm{~b}$ & $0,66 \mathrm{~b}$ & $0,55 \mathrm{c}$ & $24,09 \mathrm{ab}$ \\
13 dezembro & $3,01 \mathrm{a}$ & $1,32 \mathrm{a}$ & $1,40 \mathrm{a}$ & $1,46 \mathrm{a}$ & $16,16 \mathrm{c}$ \\
\hline
\end{tabular}

Ocorreu um aumento do enxofre na última coleta em todas as partes da planta, no entanto, esse fato não foi conseqüência do teor do nutriente no solo, que teve uma queda na última coleta

Quanto à interação entre época de amostragem e estágios de sintomatologia da doença, ela foi observada nas raízes (Tabela 49).

Tabela 49. Concentrações de enxofre na interação entre épocas de coleta e estágios de manifestação de sintomas na planta, nas raizes de plantas da variedade Natal

\begin{tabular}{crrrrr}
\hline & 0 & 1 & 2 & 3 \\
\hline 24 junho & $1,08 \mathrm{ABa}$ & $0,89 \mathrm{ABa}$ & $0,98 \mathrm{Aa}$ & $1,29 \mathrm{Aa}$ \\
29 agosto & $1,33 \mathrm{ABa}$ & $0,76 \mathrm{Bab}$ & $0,68 \mathrm{Aab}$ & $0,49 \mathrm{BCb}$ \\
3 outubro & $1,39 \mathrm{ABa}$ & $0,96 \mathrm{ABa}$ & $0,87 \mathrm{Aa}$ & $0,95 \mathrm{ABa}$ \\
8 novembro & $0,8 \mathrm{Ba}$ & $0,8 \mathrm{Ba}$ & $0,7 \mathrm{Aa}$ & $0,13 \mathrm{Cb}$ \\
13 dezembro & $1,57 \mathrm{Aa}$ & $1,54 \mathrm{Aa}$ & $1,24 \mathrm{Aa}$ & $1,67 \mathrm{Aa}$ \\
\hline
\end{tabular}

Médias seguidas pela mesma letra, minúscula na linha e maiúscula na coluna, não diferem entre si pelo teste de Tukey a $5 \%$.

Em quase todos os estágios, exceto no intermediário, ocorreram quedas do nutriente nas raízes da planta até a quarta coleta, na quinta coleta as concentrações 
voltaram a aumentar. Quanto aos estágios de sintomatologia da morte súbita, apenas nas segunda e quarta coletas é que se pode perceber uma queda do enxofre com o avanço da doença.

\subsubsection{Boro}

Ao analisar a concentração de boro dentro dos estágios de sintomatologia da morte súbita do citros, pode-se notar diferenças do nutriente nas folhas, casca do tronco e raizes (Tabela 50 ).

Tabela 50. Concentrações de boro em plantas de citros, variedade Natal, e do solo nos estágios da morte súbita do citros

\begin{tabular}{|c|c|c|c|c|c|c|}
\hline \multirow{3}{*}{$\begin{array}{c}\text { Sintomas } \\
0\end{array}$} & \multirow{2}{*}{ Folhas } & \multirow{3}{*}{$\begin{array}{l}\text { Galhos } \\
13,53 \mathrm{a}\end{array}$} & \multirow{3}{*}{$\frac{\mathrm{rg}^{-1}}{30,67 \mathrm{a}}$} & \multirow{2}{*}{ Raizes } & \multirow{2}{*}{\multicolumn{2}{|c|}{$\begin{array}{c}\text { Solo } \\
\mathrm{mg} \mathrm{dm}^{-3}\end{array}$}} \\
\hline & & & & & & \\
\hline & $55,06 a b$ & & & 23,45 a & 0,58 & $b$ \\
\hline 1 & $45,71 a b$ & 14,10 a & $26,88 a b$ & $19,10 \mathrm{ab}$ & 0,75 & a \\
\hline 2 & 59,18 a & 14,74 a & $26,41 b$ & $16,46 b$ & 0,58 & $b$ \\
\hline 3 & $42,16 \quad b$ & $12,16 \quad a$ & $26,99 a b$ & $14,77 \quad b$ & 0,59 & $a b$ \\
\hline
\end{tabular}

As plantas no último estágio mostraram concentração menor de boro nas folhas, quando comparada com os outros estágios da doença. As plantas assintomáticas apresentaram $55,06 \mathrm{mg} \mathrm{kg}^{-1}$ de boro nas folhas, as plantas em estágio inicial de sintomatologia $45,71 \mathrm{mg} \mathrm{kg}^{-1}$, em estágio intermediário tiveram um aumento para $59,18 \mathrm{mg} \mathrm{kg}^{-1}$, enquanto as plantas no ultimo estágio da doença apresentaram $42,16 \mathrm{mg} \mathrm{kg}^{-1}$ de boro, mostrando novamente uma queda. Em um experimento realizado no Brasil por Coelho et al. (1983), onde se analisou a concentração nutricional das folhas de citros de variedade Valência com o avanço do declínio do citros, notou-se um aumento da concentração do boro com a evolução da doença.

Segundo Violante Netto et al. (1988) e Rodrigues et al. (1991), a concentração de boro adequada nas folhas de citros geradas na primavera, com seis meses de idade, de ramos com fruto é de $36,00-100,00 \mathrm{mg} \mathrm{kg}^{-1}$, que quando comparada com a média das coletas realizadas de $50,52 \mathrm{mg} \mathrm{kg}^{-1} \mathrm{e}$ das plantas assintomáticas que apresentaram $55,06 \mathrm{mg} \mathrm{kg}^{-1}$, resulta em ambos os casos em valores considerados adequados. Segundo Malavolta \& Prates (1994) o valor adequado de boro nessa época é de $60,00-140,00 \mathrm{mg} \mathrm{kg}{ }^{-1}$, o que mostraria uma concentração inadequada do 
nutriente. Considerando-se o valor adequado para a época coletada no experimento de $60,00-120,00 \mathrm{mg} \mathrm{kg}^{-1}$ (Malavolta \& Prates, 1994), o nutriente mostrou-se deficiente.

$\mathrm{Na}$ casca do tronco, o boro analisado decresceu quando se comparou plantas assintomáticas com plantas sintomáticas, onde as primeiras apresentaram $30,67 \mathrm{mg}$ $\mathrm{kg}^{-1}$ de boro, já as plantas em estágio intermediário da doença apresentaram 16,46 mg $\mathrm{kg}^{-1}$.

Nas raizes também ocorreu alteração do nutriente, que decresceu com a evolução dos sintomas. O boro passou de $23,45 \mathrm{mg} \mathrm{kg}^{-1}$ nas plantas assintomáticas para $19,10 \mathrm{mg} \mathrm{kg}^{-1}$ nas plantas que se apresentavam no primeiro grau de sintomatologia da doença, até chegar a $14,77 \mathrm{mg} \mathrm{kg}^{-1}$ nas plantas no último estágio da doença. A diminuição do nutriente na casca do tronco pode ter sido conseqüência da diminuição do mesmo nas raízes.

Segundo Marschner (1997) e Violante Netto et al. (1988), esse nutriente juntamente com o cálcio, são os dois principais responsáveis pela formação do sistema radicular, por constituírem a parede celular. Sendo assim, a sua queda pode provocar uma diminuição de volume de raízes, principalmente radicelas que são as principais responsáveis pela absorção de nutrientes pela planta, como ocorreu nas duas variedades.

Essa diminuição do boro na casca do tronco e na sistema radicular pode ser explicada, em parte, pelas oscilações do mesmo no solo, no entanto não se pode esquecer que a diminuição do sistema radicular, principalmente das radicelas, influenciaram nessa queda. Os teores do nutriente no solo foram considerados adequados (Raij et al., 1996), mesmo com as alterações .

Quanto às épocas de coletas pode-se notar que o boro foi afetado nas folhas, casca do tronco e raízes (Tabela 51).

Tabela 51. Concentrações de boro em plantas de citros, variedade Natal, e do solo nas épocas de coleta

\begin{tabular}{cccccccc}
\hline Coletas & Folhas & Galhos & Casca do tronco & Raízes & $\begin{array}{c}\text { Solo } \\
\mathrm{mg} \mathrm{dm}^{-3}\end{array}$ \\
\hline 24 junho & $60,98 \mathrm{a}$ & $15,65 \mathrm{a}$ & $30,77 \mathrm{a}$ & $22,74 \mathrm{a}$ & $0,52 \mathrm{bc}$ \\
29 agosto & $59,09 \mathrm{a}$ & $12,72 \mathrm{a}$ & $26,67 \mathrm{ab}$ & $14,35 \mathrm{~b}$ & $0,69 \mathrm{ab}$ \\
3 outubro & $57,24 \mathrm{a}$ & $12,31 \mathrm{a}$ & $28,63 \mathrm{ab}$ & $22,09 \mathrm{a}$ & $0,45 \mathrm{c}$ \\
8 novembro & $34,65 \mathrm{~b}$ & $12,90 \mathrm{a}$ & $27,07 \mathrm{ab}$ & $18,51 \mathrm{~b}$ & $0,57 \mathrm{bc}$ \\
13 dezembro & $40,68 \mathrm{~b}$ & $14,58 \mathrm{a}$ & $25,56 \mathrm{~b}$ & $19,09 \mathrm{ab}$ & $0,89 \mathrm{a}$ \\
\hline
\end{tabular}


O boro nas folhas foi alterado nas duas últimas coletas, onde passaram de $60,98 \mathrm{mg} \mathrm{kg}^{-1}$ na primeira coleta para $40,68 \mathrm{mg} \mathrm{kg}^{-1}$ na ultima coleta, ocorrendo uma queda acentuada do referido nutriente, como ocorreu na variedade Pêra Rio. Na casca do tronco essa alteração também ocorreu, onde o nutriente passou de $30,77 \mathrm{mg} \mathrm{kg}^{-1}$ na primeira coleta para $28,63 \mathrm{mg} \mathrm{kg}^{-1}$ na terceira coleta, chegando a $25,56 \mathrm{mg} \mathrm{kg}^{-1}$ na ultima coleta. À medida que o boro vai decrescendo na casca do tronco, isso também ocorreu nas folhas. Este fato deve-se ao nutriente não possuir redistribuição na planta.

Com a alteração nutricional nas raizes, não se pode inferir qualquer comparação, por ser uma alteração irregular que não segue nenhuma tendência. $O$ mesmo ocorreu com o solo, onde apesar de ter ocorrido diferença entre as coletas, estas não influenciaram no boro da planta.

Quanto à interação entre época de amostragem e estágios de sintomatologia da doença, ela foi observada nas folhas (Tabela 52).

Tabela 52. Concentrações de boro na interação entre épocas de coleta e estágios de manifestação de sintomas na planta, nas folhas de plantas da variedade Natal

\begin{tabular}{crrrrr}
\hline & 0 & \multicolumn{2}{c}{1} & 2 & 3 \\
\hline 24 junho & $67,22 \mathrm{Aa}$ & $61,85 \mathrm{Aab}$ & $74,87 \mathrm{Aa}$ & $39,95 \mathrm{Ab}$ \\
29 agosto & $69,12 \mathrm{Aab}$ & $50,8 \mathrm{ABbc}$ & $73,75 \mathrm{Aa}$ & $42,69 \mathrm{Ac}$ \\
3 outubro & $58,97 \mathrm{ABa}$ & $49,81 \mathrm{ABa}$ & $70,41 \mathrm{Aa}$ & $49,76 \mathrm{Aa}$ \\
8 novembro & $35,85 \mathrm{Ca}$ & $32,02 \mathrm{Ba}$ & $36,52 \mathrm{Ba}$ & $34,15 \mathrm{Aa}$ \\
13 dezembro & $44,1 \mathrm{BCa}$ & $34,06 \mathrm{Ba}$ & $40,31 \mathrm{Ba}$ & $44,25 \mathrm{Aa}$ \\
\hline
\end{tabular}

Médias seguidas pela mesma letra, minúscula na linha e maiúscula na coluna, não diferem entre si pelo teste de Tukey a $5 \%$.

Nota-se que em quase todos os estágios de sintomatologia, exceto no último, ocorreram quedas do nutriente nas folhas da planta com o passar do tempo. No entanto essa queda não foi devida à diminuição do boro no solo. Quanto aos estágios de sintomatologia da morte súbita, apenas nas primeira e segunda coleta é que se podem perceber uma queda do boro, no ultimo estágio de sintomatologia da morte súbita. 


\subsubsection{Cobre}

Ao se analisar a concentração de cobre dentro dos estágios de sintomatologia da morte súbita do citros, não observa-se alteração nutricional em nenhuma parte da planta com o passar do tempo, diferentemente da variedade Pêra Rio, onde o cobre foi alterado nas folhas e nos galhos (Tabela 53).

Tabela 53. Concentrações de cobre em plantas de citros, variedade Natal, e do solo nos estágios da morte súbita do citros

\begin{tabular}{|c|c|c|c|c|c|c|}
\hline Sintomas & Folhas & Galhos & Casca do tronce & Raizes & & $\begin{array}{c}\text { Solo } \\
\mathrm{mg} \mathrm{dm}^{-3}\end{array}$ \\
\hline 0 & 25,27 a & 56,61 & 24,06 a & 16,77 & $a$ & 5,24 \\
\hline 1 & 28,75 a & 89,03 & 35,33 a & 9,94 & a & 8,60 a \\
\hline 2 & 25,07 a & 68,69 & 24,55 a & 8,48 & $\mathrm{a}$ & 5,79 \\
\hline 3 & 47,41 a & 103,47 & 44,37 a & 13,05 & $a$ & $5,47 a$ \\
\hline
\end{tabular}

O cobre não afetou a velocidade de desenvolvimento de sintomatologia da morte súbita do citros na variedade Natal sobre Limão 'Cravo', pois sua quantidade em toda a planta (folhas, galhos, casca do tronco e raízes) não foi alterada com o desenvolvimento da doença. $O$ cobre teve problemas quanto ao coeficiente de variação do mesmo, que foi extremamente alto, isso se deve ao experimento ter sido realizado no campo e por ser um micronutriente utilizado em defensivos e, conseqüentemente, com grandes oscilações na planta.

No caso da morte súbita não ocorreu aumento ou diminuição do cobre com o desenvolvimento da doença, no entanto, quando se compara ao avanço do declínio do citros, a concentração de cobre nas folhas aumentou com a evolução da mesma (Wutscher \& Hardesty, 1979 e Coelho et al., 1983).

Segundo Violante Netto et al. (1988) e Rodrigues et al. (1991), a concentração de cobre adequado nas folhas de citros geradas na primavera, com seis meses de idade, de ramos com fruto é de $5,00-12,00 \mathrm{mg} \mathrm{kg}^{-1}$, que quando comparada com a média das coletas realizadas de $31,62 \mathrm{mg} \mathrm{kg}^{-1}$ das plantas assintomáticas que apresentaram $25,27 \mathrm{mg} \mathrm{kg}^{-1}$, resulta nos dois casos, em valores considerados acima do adequado. Segundo Malavolta \& Prates (1994), o valor adequado do nutriente para a época de coleta é de $10,00-30,00 \mathrm{mg} \mathrm{kg}^{-1}$ e assim o cobre nas folhas mostrou concentração ideal. 
No solo, o teor de cobre também não teve diferenças com a evolução dos sintomas da plantas, sendo que apresentou um teor acima do adequado que seria 0,8 $\mathrm{mg} \mathrm{dm}^{-3}$ (Raij et al., 1996).

Quanto às épocas de coleta pode-se notar que as concentrações de cobre foram afetadas nas folhas, galhos e casca do tronco (Tabela 54).

Tabela 54. Concentrações de cobre em plantas de citros, variedade Natal, e do solo nas épocas de coleta

\begin{tabular}{|c|c|c|c|c|c|}
\hline Coletas & Folhas & Galhos & $\begin{array}{l}\text { Casca do tronco } \\
\mathrm{kg}^{-1}\end{array}$ & Raizes & $\begin{array}{c}\text { Solo } \\
\mathrm{mg} \mathrm{dm}^{-3}\end{array}$ \\
\hline 24 junho & $20,16 \quad b$ & $44,60 \mathrm{c}$ & $31,59 a b$ & 18,40 a & $6,61 a b$ \\
\hline 29 agosto & $15,58 \quad b$ & $86,64 a b$ & 40,96 a & 13,28 a & $10,28 a$ \\
\hline 3 outubro & $8,01 \mathrm{~b}$ & $56,23 \mathrm{bc}$ & $31,74 a b$ & 8,66 a & $4,02 \quad b$ \\
\hline 8 novembro & $88,74 a$ & 96,48 a & $37,63 a$ & $10,03 a$ & 5,29 b \\
\hline 13 dezembro & $25,62 b$ & 113,29 a & $18,46 \mathrm{~b}$ & 8,84 a & $5,18 \quad b$ \\
\hline
\end{tabular}

O cobre nas folhas foi alterado nas duas últimas coletas, ocorrendo um aumento acentuado, passando de 20,16 mg kg-1 e 15,58 $\mathrm{mg} \mathrm{kg}^{-1}$ na primeira e segunda coleta respectivamente, para $88,74 \mathrm{mg} \mathrm{kg}^{-1}$ na quarta coleta. Essa alteração pode ser devido à aplicação de defensivos cúpricos entre a terceira e quarta coletas. Esse aumento do nutriente ocorreu também nos galhos, no entanto, de uma maneira menos acentuada, no qual o cobre passou de $44,60 \mathrm{mg} \mathrm{kg}^{-1}$ na primeira coleta, para um valor máximo de $113,29 \mathrm{mg} \mathrm{kg}^{-1}$ na ultima coleta.

A alteração do nutriente na casca do tronco foi irregular, não seguindo uma tendência de aumento ou queda, devido, provavelmente à não redistribuição desse nutriente dentro da planta (Marschner, 1997). Quanto ao solo, ele apresentou uma estabilidade no teor de cobre nas duas primeiras coletas, e a partir dai houve uma queda. Essa queda não influenciou o comportamento do nutriente na planta.

Quanto à interação entre época de amostragem e estágios de sintomatologia da doença, ela foi observada na casca do tronco e nas folhas (Tabelas 55 e 56). 
Tabela 55. Concentrações de cobre na interação entre épocas de coleta e estágios de manifestação de sintomas na planta, na casca do tronco de plantas da variedade Natal

\begin{tabular}{cccccc}
\hline & 0 & 1 & 2 & 3 \\
\hline 24 junho & $26,75 \mathrm{Aa}$ & $38,75 \mathrm{Aa}$ & $30,30 \mathrm{Aa}$ & $30,35 \mathrm{Ba}$ \\
29 agosto & $26,55 \mathrm{Ab}$ & $27,23 \mathrm{Ab}$ & $25,30 \mathrm{Ab}$ & $84,78 \mathrm{Aa}$ \\
3 outubro & $30,85 \mathrm{Aa}$ & $29,95 \mathrm{Aa}$ & $22,35 \mathrm{Aa}$ & $43,80 \mathrm{ABa}$ \\
8 novembro & $18,60 \mathrm{Aa}$ & $58,10 \mathrm{Aa}$ & $32,10 \mathrm{Aa}$ & $41,73 \mathrm{ABa}$ \\
13 dezembro & $17,50 \mathrm{Aa}$ & $22,43 \mathrm{Aa}$ & $12,70 \mathrm{Aa}$ & $21,20 \mathrm{Ba}$ \\
\hline
\end{tabular}

Médias seguidas pela mesma letra, minúscula na linha e maiúscula na coluna, não diferem entre si pelo teste de Tukey a $5 \%$.

Apenas no estágio final de sintomatologia de morte súbita é que ocorreram diferenças entre as épocas de coleta, no entanto essas diferenças não tiveram uma tendência de queda ou aumento com o passar do tempo. Quanto aos estágios de sintomatologia da morte súbita, apenas na segunda coleta é que se pode perceber um aumento do cobre no ultimo estágio de sintomatologia da morte súbita.

Tabela 56. Concentrações de cobre na interação entre épocas de coleta e estágios de manifestação de sintomas na planta, nas folhas de plantas da variedade Natal

\begin{tabular}{crrrrr}
\hline & 0 & \multicolumn{1}{c}{1} & \multicolumn{2}{c}{2} & \multicolumn{1}{c}{3} \\
\hline 24 junho & $17,60 \mathrm{Bb}$ & $27,85 \mathrm{ABa}$ & $13,55 \mathrm{Bb}$ & $21,65 \mathrm{Ba}$ \\
29 agosto & $15,12 \mathrm{Ba}$ & $11,65 \mathrm{Ba}$ & $18,65 \mathrm{Ba}$ & $16,90 \mathrm{Ba}$ \\
3 outubro & $9,00 \mathrm{Ba}$ & $8,25 \mathrm{Ba}$ & $7,82 \mathrm{Ba}$ & $6,95 \mathrm{Ba}$ \\
8 novembro & $63,12 \mathrm{Aa}$ & $67,97 \mathrm{Aa}$ & $63,70 \mathrm{Aa}$ & $160,20 \mathrm{Aa}$ \\
13 dezembro & $21,47 \mathrm{ABa}$ & $28,00 \mathrm{ABa}$ & $21,60 \mathrm{Ba}$ & $31,40 \mathrm{Ba}$ \\
\hline
\end{tabular}

Médias seguidas pela mesma letra, minúscula na linha e maiúscula na coluna, não diferem entre si pelo teste de Tukey a $5 \%$.

Em todos os estágios de sintomatologia, ocorreram alterações do nutriente nas folhas da planta, a partir da quarta coleta. Quanto aos estágios de sintomatologia da morte súbita, apenas na primeira coleta é que ocorreu alguma alteração do nutriente, no entanto essa alteração foi irregular com o avanço da doença. 


\subsubsection{Ferro}

Ao se analisar as concentrações de ferro dentro dos estágios de sintomatologia da morte súbita do citros, notou-se que não existiu alteração nutricional em nenhuma parte da planta (Tabela 57).

Tabela 57. Concentrações de ferro em plantas de citros, variedade Natal, e do solo nos estágios da morte súbita do citros

\begin{tabular}{cccccccc}
\hline Sintomas & \multicolumn{1}{c}{ Folhas } & \multicolumn{2}{c}{ Galhos } & $\begin{array}{c}\text { Casca do tronco } \\
\text { Raízes }\end{array}$ & $\begin{array}{c}\text { Solo } \\
\mathrm{mg} \mathrm{dm}^{-3}\end{array}$ \\
\hline 0 & 191,47 a & 224,70 a & 178,15 a & 869,68 a & 19,84 a \\
1 & 171,79 a & 215,25 a & 166,07 a & 929,23 a & 21,55 a \\
2 & 158,03 a & 184,66 a & 212,47 a & 888,53 a & 24,23 a \\
3 & 148,56 a & 228,51 a & 283,96 a & 789,78 a & 19,61 a \\
\hline
\end{tabular}

O ferro não afetou a velocidade de desenvolvimento de sintomatologia da morte súbita do citros na variedade Natal sobre limão 'Cravo', pois sua quantidade em toda a planta (folhas, galhos, casca do tronco e raízes) não foi alterada com o desenvolvimento da doença. O solo também manteve seu teor de ferro inalterado com o avanço da doença, sendo este considerado adequado (Raij et al., 1996).

Não ocorreu alteração do nutriente nas folhas das plantas com a evolução da morte súbita, já em plantas afetadas com clorose variegada dos citros notou-se um aumento da concentração do nutriente com o avanço da doença (Ricci et al., 2001).

Segundo Violante Netto et al. (1988) e Rodrigues et al. (1991), a concentração de ferro adequada nas folhas de citros geradas na primavera, com seis meses de idade, de ramos com fruto é de 50,00-120,00 $\mathrm{mg} \mathrm{kg}^{-1}$, que quando comparada com a média referida às coletas realizadas de $167,46 \mathrm{mg} \mathrm{kg}^{-1}$ e das plantas assintomáticas que apresentaram $191,47 \mathrm{mg} \mathrm{kg}^{-1}$, resulta em valores considerados acima do adequado. No entanto Malavolta \& Prates (1994) consideram concentração adequada de ferro de $130,00-300,00 \mathrm{mg} \mathrm{kg}^{-1}$, sendo os valores analisados, neste caso, considerados ideais. Considerando-se a concentração adequada para a época coletada de 200,00-300,00 $\mathrm{mg} \mathrm{kg}^{-1}$ o ferro analisado é considerado deficiente.

Quanto às épocas de coleta nota-se que o ferro foi afetado nas folhas, casca do tronco e raízes (Tabela 58). 
Tabela 58. Concentrações de ferro em plantas de citros, variedade Natal, e do solo nas épocas de coleta

\begin{tabular}{crrrrrrr}
\hline Coletas & Folhas & & Galhos & \multicolumn{2}{c}{ Casca do tronco } & Raízes & \multicolumn{1}{c}{$\begin{array}{c}\text { Solo } \\
\text { mg dm }^{-3}\end{array}$} \\
\hline 24 junho & 183,79 b & 143,78 a & 201,52 ab & 353,71 c & 21,66 a \\
29 agosto & 126,33 c & 210,11 a & 160,53 ab & 1393,74 a & 21,52 a \\
3 outubro & 232,50 & a & 192,81 a & 315,94 a & 880,63 b & 21,77 a \\
8 novembro & 203,44 a & 287,19 a & 272,19 a & 844,06 b & 21,08 a \\
13 dezembro & 91,25 d & 232,50 a & 100,63 b & 611,25 bc & 20,52 a \\
\hline
\end{tabular}

O ferro nas folhas, casca do tronco e raízes alterou-se irregularmente com o passar do tempo. Não observando-se uma tendência de decréscimo ou acréscimo, nem a possibilidade de estar ocorrendo redistribuição do nutriente nas diversas partes da planta com o tempo. Pode ter ocorrido, a partir da terceira coleta, uma maior disponibilidade do nutriente depois do início das chuvas, quando o $\mathrm{Fe}^{+3}$ é reduzido para $\mathrm{Fe}^{+2}$, tornando-se mais disponivel para as plantas, isto é, em forma solúvel (Havlin et al., 1999 e Violante Netto et al., 1988). No solo, o teor de ferro não se alterou com o passar do tempo.

Quanto à interação entre época de amostragem e estágios de sintomatologia da doença, esta foi observada na casca do tronco e nas folhas (Tabelas 59 e 60).

Tabela 59. Concentrações de ferro na interação entre épocas de coleta e estágios de manifestação de sintomas na planta, na casca do tronco de plantas da variedade Natal

\begin{tabular}{ccccccc}
\hline & 0 & 1 & 2 & 3 & \\
\hline 24 junho & $241,50 \mathrm{Aa}$ & $219,30 \mathrm{Aa}$ & $234,80 \mathrm{Aa}$ & $110,60 \mathrm{Ba}$ \\
29 agosto & $168,00 \mathrm{Aa}$ & $124,80 \mathrm{Aa}$ & $196,30 \mathrm{Aa}$ & $153,00 \mathrm{Ba}$ \\
3 outubro & $198,80 \mathrm{Ab}$ & $148,80 \mathrm{Ab}$ & $198,80 \mathrm{Ab}$ & $717,50 \mathrm{Aa}$ \\
8 novembro & $171,30 \mathrm{Aa}$ & $245,00 \mathrm{Aa}$ & $326,30 \mathrm{Aa}$ & $346,30 \mathrm{ABa}$ \\
13 dezembro & $111,30 \mathrm{Aa}$ & $92,50 \mathrm{Aa}$ & $109,30 \mathrm{Aa}$ & $92,50 \mathrm{Ba}$ \\
\hline
\end{tabular}

Médias seguidas pela mesma letra, minúscula na linha e maiúscula na coluna, não diferem entre si pelo teste de Tukey a $5 \%$.

Apenas no estágio final da sintomatologia de morte súbita é que ocorreram diferenças entre as épocas de coleta, onde na terceira e quarta coletas houve um aumento do nutriente. Quanto aos estágios de sintomatologia da morte súbita, apenas na terceira coleta é que se pode perceber um aumento do ferro no último estágio de sintomatologia da morte súbita. 
Tabela 60. Concentrações de ferro na interação entre épocas de coleta e estágios de manifestação de sintomas na planta, nas folhas de plantas da variedade Natal

\begin{tabular}{cccccr}
\hline & 0 & 1 & \multicolumn{1}{c}{2} & \multicolumn{1}{c}{3} \\
\hline 24 junho & $252,05 \mathrm{ABa}$ & $143,30 \mathrm{BCb}$ & $146,22 \mathrm{ABCb}$ & $193,60 \mathrm{Aab}$ \\
29 agosto & $152,77 \mathrm{BCa}$ & $131,90 \mathrm{Ca}$ & $136,42 \mathrm{BCa}$ & $84,20 \mathrm{Aa}$ \\
3 outubro & $276,25 \mathrm{Aa}$ & $252,50 \mathrm{Aa}$ & $241,25 \mathrm{Aa}$ & $160,00 \mathrm{Aa}$ \\
8 novembro & $175,00 \mathrm{Ba}$ & $231,25 \mathrm{ABa}$ & $190,00 \mathrm{ABa}$ & $217,50 \mathrm{Aa}$ \\
13 dezembro & $101,25 \mathrm{BCa}$ & $100,00 \mathrm{Ca}$ & $76,25 \mathrm{Ca}$ & $87,50 \mathrm{Aa}$ \\
\hline
\end{tabular}

Médias seguidas pela mesma letra, minúscula na linha e maiúscula na coluna, não diferem entre si pelo teste de Tukey a $5 \%$.

$\mathrm{Em}$ todos os estágios de sintomatologia de morte súbita, exceto no último, ocorreram alterações no ferro com o passar das coletas. Essa alteração mostra que na terceira e quarta coletas ocorreram aumentos do nutriente, podendo ser devido a maior disponibilidade do nutriente no solo, quando em estado reduzido. Quanto aos estágios de sintomatologia da morte súbita, apenas na primeira coleta é que se pode perceber uma diminuição do ferro quando se compara plantas assintomáticas, $252,05 \mathrm{mg} \mathrm{kg}^{-1}$, com plantas sintomáticas, como $193,60 \mathrm{mg} \mathrm{kg}^{-1}$ nas plantas do ultimo estágio de sintomatologia.

\subsubsection{Manganês}

Ao se analisar as concentrações de manganês dentro dos estágios de sintomatologia da morte súbita do citros, notaram-se diferenças do nutriente nos galhos e casca do tronco (Tabela 61).

Tabela 61. Concentrações de manganês em plantas de citros, variedade Natal, e do solo nos estágios da morte súbita do citros

\begin{tabular}{ccccccc}
\hline Sintomas & Folhas & Galhos & $\begin{array}{c}\text { Casca do tronco } \\
\text { Raizes }\end{array}$ & $\begin{array}{c}\text { Solo } \\
\text { mg dm }^{-3}\end{array}$ \\
\hline 0 & 36,36 a & 10,33 b & 12,85 b & 18,48 a & 21,74 a \\
1 & 49,98 a & 11,95 ab & 14,83 b & 21,98 a & 22,32 a \\
2 & $37,50 \mathrm{a}$ & 11,27 ab & 16,98 ab & 21,75 a & 23,97 a \\
3 & 40,87 a & 14,56 a & 22,05 a & 18,88 a & 19,47 a \\
\hline
\end{tabular}

À medida que os sintomas evoluíram as concentrações de manganês nos galhos aumentaram. O nutriente passou de $10,33 \mathrm{mg} \mathrm{kg}^{-1}$ nas plantas assintomáticas 
para $14,56 \mathrm{mg} \mathrm{kg}^{-1}$ nas plantas no último estágio de sintomatologia da morte súbita do citros.

$\mathrm{Na}$ casca do tronco ocorreu aumento, sendo que o nutriente passou de 12,85 $\mathrm{mg} \mathrm{kg}^{-1}$ nas plantas assintomáticas para $22,05 \mathrm{mg} \mathrm{kg}^{-1}$ nas plantas no ultimo estágio da doença. Ao contrario do que aconteceu com a variedade Pêra Rio, onde com a evolução da doença, o nutriente diminuiu. Albrigo \& Willians (1984) observaram aumento na concentração de manganês no tronco das plantas, com o avanço do declínio dos citros.

O aumento do nutriente nos galhos pode ser devido à diminuição da massa seca da planta, isto é, à queda de folhas e menor desenvolvimento da parte aérea e do sistema radicular e o conseqüente acúmulo de manganês nesta parte da planta (Pivetta, 2003 e Fundecitrus, 2002a).

No caso da morte súbita, não ocorreu alteração do manganês foliar, como na variedade Natal. Em experimento realizado com o declínio do citros observou-se que a concentração de manganês diminuiu com o avanço da doença (Tavares, 1987). Na clorose variegada do citros ocorre o contrário, o manganês foliar aumenta com a doença (Ricci et al., 2001).

Segundo Violante Netto et al. (1988) e Rodrigues et al. (1991), a concentração de manganês adequada nas folhas de citros, geradas na primavera, com seis meses de idade, de ramos com fruto é de $25,00-49,00 \mathrm{mg} \mathrm{kg}^{-1}$, que quando comparada com a média das coletas realizadas de $41,17 \mathrm{mg} \mathrm{kg}^{-1}$, e das plantas assintomáticas que apresentaram $36,36 \mathrm{mg} \mathrm{kg}^{-1}$, resulta em ambos os casos, em valores considerados adequados. Considerando-se o valor adequado para a época coletada no experimento de $25,00-50,00 \mathrm{mg} \mathrm{kg}^{-1}$ (Malavolta \& Prates, 1994), o manganês nas folhas continua avaliado como ótimo.

O solo manteve o teor de manganês inalterado com o aumento da sintomatologia, tendo um teor considerado acima de adequado que seria de $5 \mathrm{mg} \mathrm{dm}^{-3}$ (Raij et al., 1996).

Quanto às épocas de coletas nota-se que o manganês foi afetado nos galhos e casca do tronco (Tabela 62). 
Tabela 62. Concentrações de manganês em plantas de citros, variedade Natal, e do solo nas épocas de coleta

\begin{tabular}{|c|c|c|c|c|c|c|}
\hline Coletas & Folhas & Galhos & $\begin{array}{l}\text { Casca do tronco } \\
\mathrm{kg}^{-1}\end{array}$ & Raizes & $\begin{array}{c}\text { Solo } \\
\mathrm{mg} \mathrm{dm}^{-3}\end{array}$ & \\
\hline 24 junho & 47,49 a & $7,28 \quad b$ & $14,37 b$ & $22,33 a$ & 22,77 & b \\
\hline 29 agosto & 40,94 a & $12,54 a$ & $20,99 a$ & $20,55 a$ & 29,85 & a \\
\hline 3 outubro & $40,89 a$ & 11,66 a & $17,71 \mathrm{ab}$ & $20,21 \quad a$ & 20,80 & $\mathrm{bc}$ \\
\hline 8 novembro & 39,38 a & 15,73 a & $17,02 a b$ & 14,66 a & 17,87 & c \\
\hline 13 dezembro & $37,18 \quad$ a & 12,91 a & $13,28 \quad b$ & $19,76 \quad a$ & $18,09 \mathrm{c}$ & c \\
\hline
\end{tabular}

Ocorreu alteração no manganês nos galhos, pois houve um aumento do nutriente após a segunda coleta, passando de $7,28 \mathrm{mg} \mathrm{kg}^{-1}$ na primeira coleta para $12,54 \mathrm{mg} \mathrm{kg}^{-1}$ na segunda e $12,91 \mathrm{mg} \mathrm{kg}^{-1}$ na última coleta. Na casca do tronco ocorreu um aumento do manganês na segunda coleta, passando de $14,37 \mathrm{mg} \mathrm{kg}^{-1}$ na primeira coleta para 20,99 mg kg-1 na segunda e teve posterior decréscimo, chegando a 13,28 $\mathrm{mg} \mathrm{kg}^{-1}$ na ultima coleta.

Quanto ao solo, este teve um comportamento semelhante ao da casca do tronco, isto é, teve um aumento na segunda coleta, passando de $22,77 \mathrm{mg} \mathrm{dm}^{-3} \mathrm{na}$ primeira coleta para $29,85 \mathrm{mg} \mathrm{dm}^{-3}$ na segunda coleta e posterior decréscimo, chegando a $18,09 \mathrm{mg} \mathrm{dm}^{-3}$ na ultima coleta.

Quanto à interação entre época de amostragem e estágios de sintomatologia da doença, esta foi observada na casca do tronco (Tabela 63).

Tabela 63. Concentrações de manganês na interação entre épocas de coleta e estágios de manifestação de sintomas na planta, na casca do tronco de plantas da variedade Natal

\begin{tabular}{cccccc}
\hline & 0 & 1 & 2 & 3 \\
\hline 24 junho & $11,60 \mathrm{Aa}$ & $13,83 \mathrm{Aa}$ & $18,48 \mathrm{Aa}$ & $13,58 \mathrm{Ba}$ \\
29 agosto & $14,85 \mathrm{Ab}$ & $18,88 \mathrm{Ab}$ & $18,05 \mathrm{Ab}$ & $32,20 \mathrm{Aa}$ \\
3 outubro & $16,15 \mathrm{Aa}$ & $14,38 \mathrm{Aa}$ & $17,73 \mathrm{Aa}$ & $22,60 \mathrm{ABa}$ \\
8 novembro & $11,50 \mathrm{Aa}$ & $16,70 \mathrm{Aa}$ & $16,85 \mathrm{Aa}$ & $23,05 \mathrm{ABa}$ \\
13 dezembro & $10,10 \mathrm{Aa}$ & $10,43 \mathrm{Aa}$ & $13,78 \mathrm{Aa}$ & $18,80 \mathrm{Ba}$ \\
\hline
\end{tabular}

Médias seguidas pela mesma letra, minúscula na linha e maiúscula na coluna, não diferem entre si pelo teste de Tukey a $5 \%$.

Apenas no estágio final da sintomatologia de morte súbita é que ocorreram diferenças entre as épocas de coleta, onde na segunda coleta ocorreu um aumento do nutriente, e um posterior decréscimo com o passar das coletas. Quanto aos estágios 
de sintomatologia da morte súbita, apenas na segunda coleta é que se pode perceber um aumento do manganês no ultimo estágio de sintomatologia da morte súbita.

\subsubsection{Zinco}

Ao se analisar as concentrações de zinco dentro dos estágios de sintomatologia da morte súbita do citros, nota-se diferenças do nutriente nas raizes (Tabela 64).

Tabela 64. Concentrações de zinco em plantas de citros, variedade Natal, e do solo nos estágios da morte súbita do citros

\begin{tabular}{cccccrrr}
\hline Sintomas & Folha & Galho & Casca do tronco & Raiz & \multicolumn{1}{c}{$\begin{array}{c}\text { Solo } \\
\text { mg dm }^{-3}\end{array}$} \\
\hline 0 & 23,27 & a & 25,81 a & 45,51 a & 115,41 a & 2,98 a \\
1 & 32,65 a & 28,94 a & 45,00 a & 79,01 b & 2,66 a \\
2 & 23,12 a & 27,84 a & 47,56 a & 59,80 b & 3,32 a \\
3 & 30,89 a & 42,62 a & 48,66 a & 72,52 b & 2,48 a \\
\hline
\end{tabular}

Nas raízes ocorreu uma diminuição do zinco com o aparecimento de sintomas da doença, como na variedade Pêra Rio. O zinco passou de $115,41 \mathrm{mg} \mathrm{kg}^{-1}$ nas plantas assintomáticas para $79,01 \mathrm{mg} \mathrm{kg}^{-1}$ nas plantas no primeiro estágio da morte súbita do citros, chegando a $59,80 \mathrm{mg} \mathrm{kg}^{-1}$ nas raizes de plantas em estágio intermediário da doença. Não houve alteração do mesmo com o desenvolvimento dos sintomas da doença, sendo que o teor do nutriente no solo foi considerado adequado (Raij et al., 1996).

Quanto à concentração de zinco na casca do tronco, mais uma vez não ocorreu alteração com o avanço da morte súbita. No entanto, quando se trabalhou com o declinio do citros este nutriente aumentou no tronco, com a evolução da doença (Albrigo \& Young, 1979 e Willians \& Albrigo, 1984).

Na variedade Pêra Rio ocorre um aumento da concentração de zinco nas folhas com o avanço da doença, na variedade Natal, não houve alteração do nutriente com a morte súbita. Em um experimento realizado com declínio do citros, a concentração de zinco foliar aumentou com o desenvolvimento da doença (Wutscher \& Hardesty, 1979).

Segundo Violante Netto et al. (1988) e Rodrigues et al. (1991), a concentração de zinco adequada nas folhas de citros geradas na primavera, com seis meses de idade, de ramos com fruto é de $25,00-49,00 \mathrm{mg} \mathrm{kg}^{-1}$, que quando comparada com a média das coletas realizadas de $27,48 \mathrm{mg} \mathrm{kg}^{-1}$ foi considerada adequada, das plantas 
assintomáticas que apresentaram $23,27 \mathrm{mg} \mathrm{kg}^{-1}$ resultou no primeiro caso em valores adequados e no segundo abaixo do adequado. Considerando-se a concentração adequada para a época coletada de 25,00-50,00 $\mathrm{mg} \mathrm{kg}^{-1}$ (Malavolta \& Prates, 1994), o zinco nas folhas foi considerado adequado.

Quanto às épocas de coletas nota-se que o zinco foi afetado nos galhos e raízes (Tabela 65 ).

Tabela 65. Concentrações de zinco em plantas de citros, variedade Pêra Rio, e do solo nas épocas de coleta

\begin{tabular}{|c|c|c|c|c|c|}
\hline Coletas & Folhas & Galhos & $\begin{array}{l}\text { Casca do tronco } \\
\mathrm{kg}^{-1}\end{array}$ & $\begin{array}{l}\text { Raizes } \\
\end{array}$ & $\begin{array}{c}\text { Solo } \\
\mathrm{mg} \mathrm{dm}^{-3} \\
\end{array}$ \\
\hline 24 junho & 35,76 a & $19,54 \mathrm{~b}$ & 45,88 a & $90,28 a b$ & $3,17 b$ \\
\hline 29 agosto & 23,52 a & 39,49 a & $50,19 a$ & $84,94 a b$ & 4,62 a \\
\hline 3 outubro & 21,65 a & $27,33 a b$ & 48,30 a & $100,63 a$ & $2,01 \mathrm{c}$ \\
\hline 8 novembro & 29,70 a & $31,94 a b$ & 45,99 a & $57,16 a b$ & $2,19 b c$ \\
\hline 13 dezembro & 26,76 a & 38,21 a & 43,04 a & $53,69 \mathrm{~b}$ & $2,31 \mathrm{bc}$ \\
\hline
\end{tabular}

O zinco nos galhos e nas raízes alterou irregularmente com o passar das coletas não havendo uma tendência de acréscimo ou decréscimo do nutriente. $O$ mesmo ocorreu com o solo, isto é, uma alteração irregular do nutriente com o passar do tempo.

Quanto à interação entre época de amostragem e estágios de sintomatologia da doença, esta foi observada nos galhos (Tabela 66).

Tabela 66. Concentrações de zinco na interação entre épocas de coleta e estágios de manifestação de sintomas na planta, nos galhos de plantas da variedade Natal

\begin{tabular}{cccccc}
\hline & 0 & 1 & 2 & 3 \\
\hline 24 junho & $23,45 \mathrm{Aa}$ & $16,80 \mathrm{Aa}$ & $19,38 \mathrm{Aa}$ & $18,58 \mathrm{Ba}$ \\
29 agosto & $19,90 \mathrm{Ab}$ & $29,00 \mathrm{Ab}$ & $36,78 \mathrm{Ab}$ & $82,30 \mathrm{Aa}$ \\
3 outubro & $25,00 \mathrm{Aa}$ & $27,40 \mathrm{Aa}$ & $26,40 \mathrm{Aa}$ & $30,53 \mathrm{Ba}$ \\
8 novembro & $28,05 \mathrm{Aa}$ & $32,70 \mathrm{Aa}$ & $27,10 \mathrm{Aa}$ & $39,90 \mathrm{Ba}$ \\
13 dezembro & $32,65 \mathrm{Aa}$ & $38,90 \mathrm{Aa}$ & $39,55 \mathrm{Aa}$ & $41,80 \mathrm{ABa}$ \\
\hline
\end{tabular}

Médias seguidas pela mesma letra, minúscula na linha e maiúscula na coluna, não diferem entre si pelo teste de Tukey a $5 \%$.

Apenas no estágio final de sintomatologia de morte súbita é que ocorreram diferenças entre as épocas de coleta que foram aleatórias com o passar do tempo. Quanto aos estágios de sintomatologia da morte súbita, apenas na segunda coleta é 
que se pôde perceber um aumento do zinco no ultimo estágio de sintomatologia da morte súbita, sendo que o nutriente passou de $19,90 \mathrm{mg} \mathrm{kg}^{-1}$ nas plantas assintomáticas para $82,30 \mathrm{mg} \mathrm{kg}^{-1}$ nas plantas no ultimo estágio da doença 


\section{CONCLUSÕES}

As conseqüências nutricionais da MSC devem ser avaliadas nas varias espécies com o problema, não sendo possível generalizar-se.

A doença prejudica tanto a absorção de nutrientes pela planta, diminuindo o sistema radicular, quanto a sua redistribuição, através do entupimento do floema.

O comportamento nutricional mostrou-se variado quanto às épocas de amostragem, dependendo da parte da planta, da variedade de copa e do nutriente estudado. 


\section{REFERÊNCIAS BIBLIOGRÁFICAS}

ALBRIGO, L.G.; SYVERTSEN, J.P.; YOUNG, R.H. Stress symptoms of citrus trees in succesive stages of decline due to blight. Journal of the American Society for Horticultural Science, v.111, n.3, p.465-470, 1986.

ALBRIGO, L.G.; YOUNG, R.H. Citrus tree decline complex and diagnostic identification of blight. Proccedings of the Florida State for Horticultural Society, v.92, n.1, p.61-63, 1979

CASTRO, P.R.C.; MARINHO, C.S.; PAIVA, R.; MENEGUCCI, J.L.P. Fisiologia da produção dos citros. Informe Agropecuário, v.22, n.209, p.26-38, 2001.

CENTRO DE CITRICULTURA SYLVIO MEREIRA Nova doença já causa prejuízos a pomares de São Paulo e Minas Gerais. Informativo Centro de Citricultura, n.76, p. 1-4, 2001

CHAPMAN, H.D. The mineral nutrition of citrus. In: REUTHER, W.; BATCHELOR, L.D.; WEBBER, H.J. (Ed.) The citrus industry. Berkeley: University of California, Division of Agricultural Sciences, 1968, p.127-289.

COELHO, Y.S.; PAGUIO, O.R.; HIROCE, R. Situação nutricional de plantas cítricas afetadas pelo declínio nos estados da Bahia e São Paulo. In: CONGRESSO BRASILEIRO DE FRUTICULTURA,7., Florianópolis, 1983. Anais. Florianópolis: Sociedade Brasileira de Fruticultura, 1983. v.1, p.416-423. 
DECHEN, A.R. Deficiência de cálcio e magnésio nos solos e nas plantas. In RAIJ, B. van; BATAGLIA, O.C.; SILVA, N.M. (coord.). Acidez e calagem no Brasil, Campinas, Sociedade Brasileira de Ciência do Solo, 1983. p.87-95.

EMPRESA BRASILEIRA DE PESQUISA AGROPECUÁRIA Centro Nacional de Pesquisa de Solos. Sistema brasileiro de classificação de solos. Rio de Janeiro, 1999. 412p.

EPSTEIN, E. Nutrição mineral das plantas: princípios e perspectivas. Rio de Janeiro, Livros Técnicos e Científicos, 1975. 341p.

FERNANDES, N.G.; BASSANEZI, R.B. Doença de causa desconhecida afeta pomares cítricos no norte de São Paulo e Sul do Triângulo Mineiro. Summa Phytopathologica, v.27, n.1, p.93, 2001.

FIGUEIREDO, J.O. Variedades copa de valor comercial. In: RODRIGUEZ, O; VIÉGAS, F.; POMPEU JUNIOR, J.; AMARO, A.A (Ed.). Citricultura brasileira. Campinas: Fundação Cargill, 1991. v.1, cap. 8, p.245-248.

FNP CONSULTORIA \& COMÉRCIO. Agrianual 2004: anuário da agricultura brasileira. São Paulo, 2004. 545p.

FUNDECITRUS. Nova doença mobiliza Fundecitrus. Revista Fundecitrus, v.14, n.108 p.8-12, 2002a.

FUNDECITRUS. Mobilização total contra MSC. Revista Fundecitrus, v.16, n.109, p.8-10, 2002b.

FUNDECITRUS. Investigação em várias frentes. Revista Fundecitrus, v.14, n.109, p. $11-13,2002 c$.

FUNDECITRUS. Alternativas para o limão 'Cravo'. Revista Fundecitrus, v.18, n.110, p. $12-14,2002 d$. 
FUNDECITRUS. Proteção total. Revista Fundecitrus, v.14, n.112, p.4-6, $2002 \mathrm{e}$.

FUNDECITRUS. Morte súbita dos citros especial - entenda o que é a nova doença,. Revista Fundecitrus, p.1-11, 2002. Edição especial.

FUNDECITRUS. A ciência contra a morte súbita. Revista Fundecitrus, v.19, n.115, p.12-15, 2003a.

FUNDECITRUS. Subenxertia dá certo. Revista Fundecitrus, v.19, n.116, p.10-11, 2003b.

FUNDECITRUS. MSC reduz produtividade. Revista Fundecitrus, v.19, n.119, p.11, 2003c.

FUNDECITRUS. MSC evolui. Revista Fundecitrus, v.20, n.120, p.6-7, 2004a.

FUNDECITRUS. Suspeita Confirmada, Revista Fundecitrus, v.20, n. 121, p.10-11, 2004b.

FUNDECITRUS. Pesquisa estuda porta-enxertos. Revista Fundecitrus, v.20, n.122, p. 12-13, 2004c.

GIROTO, E.J. Correlações de nutrientes em tecidos de laranjeiras (Citrus sinensis (L.) Osbeck cv. Valencia] e o declínio dos citros. Lavras, 1990. 77 p. Dissertação (MS) - Universidade Federal de Lavras

HAVLIN, J.L.; BEATON, J.D.; TISDALE, S.L.; NELSON, W.L. Soil fertility and fertilizers: an introduction to nutrient management, 6.ed. New Jersey: Prentice Hall: 1999. $498 \mathrm{p}$.

KAMPFER, M.; UEXKULL, H.R. von. Nuevos conocimientos sobre la fertilización de los citricos. Hanover, Verlag Gesselschaft fur Ackerbau, 3.ed., 1966, 104p. 
KIEHL, E.J. Fertilizantes orgânicos. Informações Agronômicas POTAFOS, n.30, p.3-4, 1985.

LYONS, C.G.; ROUSE, R.E. Observations of grapefruit tree decline in Texas. Journal of the Rio Grande Valley Horticultural Society, v.33, n.1, p.71-74, 1979.

MALAVOLTA, E. ABC da adubação. São Paulo: Agronômica Ceres, 1970. 189p.

MALAVOLTA, E. Nutrição mineral e adubação dos citros. In: YAMADA, T. (Ed.). Nutrição mineral e adubação dos citros. Piracicaba: Associação Brasileira para a Pesquisa da Potassa e do Fosfato, 1979. p. 13-70. (Boletim Técnico, 5).

MALAVOLTA, E. Elementos de nutrição mineral de plantas. Piracicaba: Agronômica Ceres, 1980. 251p.

MALAVOLTA, E; GOMES, F.P. Foliar diagnosis in Brazil. In: REUTHER, W. (Ed.). Plant analysis and fertilizer problems. Washington: American Institute of Biology Science, 1960. p.180-189.

MALAVOLTA, E.; PRATES, H.S. Seja doutor dos seus citros. Informações Agronômicas, POTAFOS n.65, p-16, 1994

MALAVOLTA, E; VIOLANTE NETTO, A. Nutrição mineral, calagem, gessagem e adubação dos citros, Piracicaba: Associação Brasileira para a Pesquisa da Potassa e do Fosfato, 1989. 153 p.

MALAVOLTA, E.; VITTI, G.C.; OLIVEIRA, S.A. de. Avaliação do estado nutricional das plantas. 2.ed. Piracicaba: Associação Brasileira para a pesquisa da Potassa e do Fosfato, 1997. 319p.

MARSCHNER, $H$. Mineral nutrition of higher plants. London: Academic Press, 1997. 889p. 
MENGEL, K.; KIRKBY, E.A. Principles of plant nutrition. Worbland: International Potash Institute, 2001. 849 p.

MÜLLER, G.W.; COSTA, A.S. Moléstias de vírus e micoplasmas de citros. In RODRIGUEZ, O.; VIÉGAS, F. (Coord.). Citricultura brasileira. Campinas: Fundação Cargill, 1980. v.2, p.565-607.

MÜLLER, G.W.; NEGRI, J.D.; AGUILAR-VILDOSO, C.I; MATTOS Jr., D.; POMPEU Jr., J.; TEÓFILO SOBRINHO, J.; CARVALHO, S.A.; GIROTTO, L.F.; MACHADO, M.A. Morte Súbita dos Citros: uma nova doença na citricultura brasileira, Laranja, v. 23, n. 2, p. $371-386,2002$.

PEREIRA, E.B.C. Avaliação nutricional de cultivares de citros no estádio de desenvolvimento vegetativo. Lavras, 1985. 124 p. Dissertação (M.S.) Universidade Federal de Lavras.

PIVETA, M. Risco de infarto no laranjal. Pesquisa Fapesp, n.85, p.17-20, 2003.

POMPEU JUNIOR, J. Porta- enxerto. In: RODRIGUEZ, O.; VIÉGAS, F.; POMPEU JUNIOR, J.; AMARO, A.A. (Ed.). Citricultura brasileira Campinas: Fundação Cargill, 1991, v.1, cap. 9, 274p.

RAIJ, R. van; ANDRADE, J.C.; CANTARELLA H.; QUAGGIO, J.A. (Ed.) Análise química para avaliação da fertilidade de solos tropicais. Campinas: Institutọ Agronômico, 2001. 285p

RAIJ, B. van; CANTARELLA, H.; QUAGGIO, J.A.; FURLANI, A.M.C. Recomendações de adubação e calagem para o estado de São Paulo. 2.ed. Campinas: IAC, 1996. 279 p. (IAC - Boletim Técnico, 100) 
RICCI, A.P.; MOURÃO FILHO, F.A.A.; ARAÚJO, P.S.R.; BERETTA, M.J.G.; DERRICK, K. Teores de nutrientes em laranjeiras 'Pêra' em função da clorose variegada dos citros, Laranja, v.22, n.2, p.517-531, 2001.

RODRIGUES, O.; VIEGAS, F.; POMPEU JUNIOR, J.; AMARO, A.S. Citricultura Brasileira. 2.ed. Campinas: Fundação Cargill, 1991. v.2, p.491

RODRIGUEZ, O. Aspectos fisiológicos, nutrição e adubação dos citros In: RODRIGUEZ, O.; VIÉGAS, F.; POMPEU Jr, J.; AMARO, A.A. (Ed.). Citricultura brasileira Campinas: Fundação Cargill, 1991. v.1, cap. 14, p.419-455.

RODRIGUEZ, O. Aspectos principais da nutrição e carências minerais dos citros. In: TEÓFILO SOBRINHO, J. (Ed.) Palestras e debates sobre citricultura. Cordeirópolis: IAC, 1977. p.37-57.

SARRUGE, J.R.; HAAG, H.P. Análises químicas em plantas. Piracicaba: ESALQ, 1974. 56p.

SAS INSTITUTE. SAS-WINDOWS. property software release 6.08. Cary, 1989.

SMITH, P.F. Citrus nutrition. In: CHILDERS, N.F. (Ed.) Temperate to tropical fruit nutrition. Somerville: Somerset Press, 1966b. cap. 6, p.174-207.

SMITH, P.F. Cleaf analysis of citrus. In: CHILDERS, N.F., (Ed.) Temperate to tropical fruit nutrition. Somerville: Somerset Press, 1966a. cap.8, p.208-228.

SOUZA, M. de Adubação das plantas cítricas. Informe Agropecuário, Belo Horizonte, v.5, n.52, p.26-31, 1979.

TROCME, S.; GRAS, R. Suelo y fertilización em fruticultura. Madrid, MundiPrensa, 1966. $364 \mathrm{p}$. 
TAVARES, E.D. Avaliação do estado nutricional da laranjeira (Citrus sinensis (L.) Osbeck) cv. valência com o declínio dos citros, Lavras, 1987. 64p. Dissertação (MS) - Universidade Federal de Lavras

VIOLANTE NETTO, A.; RAIJ, B. van; BLASCO, E.E.A.; VITTI, G.C.; CANTARELLA, H.; TEÓFILO SOBRINHO, J., GUAGGIO, J.A.; NEGRI, J.D.; RODRIGUEZ, O.; BATAGLIA, O.C.; MALAVOLTA, E. Recomendações de adubação e calagem para citros no Estado de São Paulo. Cordeirópolis: Estação Experimental de Limeira, $1988.13 \mathrm{p}$.

VITTI, G.C. Avaliação e interpretação do enxofre no solo e na planta. Jaboticabal: FUNEP, 1989. 37p.

WILLIANS, G.L.; ALBRIGO, L.G. Some inorganic elements changes in trunk floem of healthy and blight-affected citrus trees. Journal of the American Society for Horticultural Science, n.109, v.3, p.437-440, 1984.

WUTSCHER, H. Seasonal changes in zinc and water-soluble phenolics in the outer trunk wood of healthy and blight-effected sweet orange trees. HortScience, v. 16, n.2, p.157-158, 1981.

WUTSCHER, H.; HARDESTRY, C.A. Concentrations of 14 elements in tissue of blight affected and healthy 'Valencia' orange trees. Journal of the American Society for Horticultural Science, v.104, n.1, p.9-11, 1979.

WUTSCHER, H.; McDONALD, R.E. Mineral elements and organic acids in branch and root xilem sap of healthy and blight-affected sweet orange trees. Journal of the American Society for Horticultural Science, v.111, n.3, p.426-429, 1986. 